NASA/TM-2010-216826

INOR-432

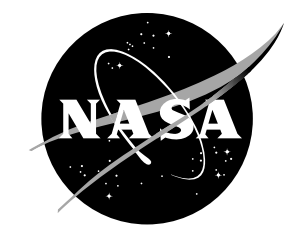

\title{
Synthesis of Two New Group 13 Benzoato-Chloro Complexes: A Structural Study of Gallium and Indium Chelating Carboxylates
}

\section{Stan A. Duraj}

Cleveland State University, Cleveland, Ohio

Aloysius F. Hepp

Glenn Research Center, Cleveland, Ohio

Robert Woloszynek and John D. Protasiewicz

Case Western Reserve University, Cleveland, Ohio

Michael Dequeant

Hendrix College, Conway, Arkansas

Tong Ren

Purdue University, West Lafayette, Indiana 


\section{NASA STI Program . . . in Profile}

Since its founding, NASA has been dedicated to the advancement of aeronautics and space science. The NASA Scientific and Technical Information (STI) program plays a key part in helping NASA maintain this important role.

The NASA STI Program operates under the auspices of the Agency Chief Information Officer. It collects, organizes, provides for archiving, and disseminates NASA's STI. The NASA STI program provides access to the NASA Aeronautics and Space Database and its public interface, the NASA Technical Reports Server, thus providing one of the largest collections of aeronautical and space science STI in the world. Results are published in both non-NASA channels and by NASA in the NASA STI Report Series, which includes the following report types:

- TECHNICAL PUBLICATION. Reports of completed research or a major significant phase of research that present the results of NASA programs and include extensive data or theoretical analysis. Includes compilations of significant scientific and technical data and information deemed to be of continuing reference value. NASA counterpart of peer-reviewed formal professional papers but has less stringent limitations on manuscript length and extent of graphic presentations.

- TECHNICAL MEMORANDUM. Scientific and technical findings that are preliminary or of specialized interest, e.g., quick release reports, working papers, and bibliographies that contain minimal annotation. Does not contain extensive analysis.

- CONTRACTOR REPORT. Scientific and technical findings by NASA-sponsored contractors and grantees.
- CONFERENCE PUBLICATION. Collected papers from scientific and technical conferences, symposia, seminars, or other meetings sponsored or cosponsored by NASA.

- SPECIAL PUBLICATION. Scientific, technical, or historical information from NASA programs, projects, and missions, often concerned with subjects having substantial public interest.

- TECHNICAL TRANSLATION. Englishlanguage translations of foreign scientific and technical material pertinent to NASA's mission.

Specialized services also include creating custom thesauri, building customized databases, organizing and publishing research results.

For more information about the NASA STI program, see the following:

- Access the NASA STI program home page at http://www.sti.nasa.gov

- E-mail your question via the Internet to help@ sti.nasa.gov

- Fax your question to the NASA STI Help Desk at 443-757-5803

- Telephone the NASA STI Help Desk at 443-757-5802

- Write to: NASA Center for AeroSpace Information (CASI) 7115 Standard Drive Hanover, MD 21076-1320 
Synthesis of Two New Group 13 Benzoato-Chloro Complexes: A Structural Study of Gallium and Indium Chelating Carboxylates

Stan A. Duraj

Cleveland State University, Cleveland, Ohio

Aloysius F. Hepp

Glenn Research Center, Cleveland, Ohio

Robert Woloszynek and John D. Protasiewicz

Case Western Reserve University, Cleveland, Ohio

Michael Dequeant

Hendrix College, Conway, Arkansas

Tong Ren

Purdue University, West Lafayette, Indiana

Prepared for the

Spring 2010 National Meeting and Exposition

sponsored by the American Chemical Society

San Francisco, California, March 21-25, 2010

National Aeronautics and

Space Administration

Glenn Research Center

Cleveland, Ohio 44135 


\section{Acknowledgments}

S.A. Duraj thanks Cleveland State University for support during a sabbatical at Case Western Reserve University. A.F. Hepp acknowledges support from the NASA Glenn Research Center's Internal Research and Development Fund. S.A. Duraj, R.A. Woloszynek, and J.D. Protasiewicz acknowledge support from the Department of Chemistry, Case Western Reserve University.

M. Dequeant and T. Ren acknowledge support from the Department of Chemistry at University of Miami Coral Gables, Florida, where the structural data were collected and solved.

Trade names and trademarks are used in this report for identification only. Their usage does not constitute an official endorsement, either expressed or implied, by the National Aeronautics and Space Administration.

Level of Review: This material has been technically reviewed by technical management.

Available from

NASA Center for Aerospace Information 7115 Standard Drive

Hanover, MD 21076-1320
National Technical Information Service 5301 Shawnee Road Alexandria, VA 22312

Available electronically at http://gltrs.grc.nasa.gov 


\title{
Synthesis of Two New Group 13 Benzoato-Chloro Complexes: A Structural Study of Gallium and Indium Chelating Carboxylates
}

\author{
Stan A. Duraj \\ Cleveland State University \\ Cleveland, Ohio 44115 \\ Aloysius F. Hepp \\ National Aeronautics and Space Administration \\ Glenn Research Center \\ Cleveland, Ohio 44135 \\ Robert Woloszynek and John D. Protasiewicz \\ Case Western Reserve University \\ Cleveland, Ohio 44106 \\ Michael Dequeant \\ Hendrix College \\ Conway, Arkansas 72032 \\ Tong Ren \\ Purdue University \\ West Lafayette, Indiana 47907
}

\begin{abstract}
Two new heteroleptic chelated-benzoato gallium (III) and indium (III) complexes have been prepared and structurally characterized. The molecular structures of $\left[\mathrm{GaCl}_{2}(4-\mathrm{Mepy})_{2}\left(\mathrm{O}_{2} \mathrm{CPh}\right)\right] \cdot 4-\mathrm{Mepy}(1)$ and $\left[\mathrm{InCl}(4-\mathrm{Mepy})_{2}\left(\mathrm{O}_{2} \mathrm{CPh}\right)_{2}\right] \bullet 4-\mathrm{Mepy}(2)$ have been determined by single-crystal x-ray diffraction. The gallium compound (1) is a distorted octahedron with cis-chloride ligands co-planar with the chelating benzoate and the 4-methylpyridines trans to each other. This is the first example of a Ga(III) structure with a chelating benzoate. The indium compound (2) is a distorted pentagonal bipyramid with two chelating benzoates, one 4-methylpyridine in the plane and a chloride trans to the other 4-methylpyridine. The indium bis-benzoate is an unusual example of a seven-coordinate structure with classical ligands. Both complexes, which due to the chelates, could also be described as pseudo-trigonal bipyramidal, include a three-bladed motif with three roughly parallel aromatic rings that along with a solvent of crystallization and electron-withdrawing chloride ligand(s) stabilize the solid-state structures.
\end{abstract}

\subsection{Introduction}

In recent years, there has been an intense and ongoing interest in the study of gallium and indium complexes for use as potential precursors for electronic materials via chemical spray pyrolysis or chemical solution deposition (Refs. 1 to 4). Ideally, such precursors should be readily prepared from inexpensive starting materials, be easily handled or preferably air-stable, and decompose cleanly for chemically-driven processing to be economically viable (Refs. 5 and 6). In our on-going research, we are preparing derivatives of gallium and indium chlorides with chalcogenide ligands, determining their single-crystal structures and studying further reactions to produce new precursors for solid-state materials (Refs. 6 to 9). For example, oxidative addition of lower-valent $\mathrm{Ga}$ and In chlorides (or metal) via addition of carboxylate $\left(\mathrm{RCO}_{2}^{-}\right)$or dithiocarbamate $\left(\mathrm{S}_{2} \mathrm{C}-\mathrm{NR}_{2}{ }^{-}\right)$ligands by reaction with the respective 
chalcogenide-bonded dimers affords compounds that are amenable to characterization, particularly complexes that are stabilized by pyridine-like ligands (Refs. 1 to 10). Use of 4-methylpyridine or $\gamma$ picoline solvent (ligands) has yielded complexes that most readily provide single crystals suitable for x-ray diffraction studies. Previously, reaction of sodium benzoate with $\mathrm{Ga}_{2} \mathrm{Cl}_{4}$ in 4-methylpyridine resulted in isolation and structural characterization of the first oxo-centered main group trinuclear carboxylate, $\left[\mathrm{Ga}_{3}\left(\mu_{3}-\mathrm{O}\right)\left(\mu-\mathrm{O}_{2} \mathrm{CC}_{6} \mathrm{H}_{5}\right)_{6}\left(4-\mathrm{MeC}_{5} \mathrm{H}_{5} \mathrm{~N}\right)_{3}\right]\left(\mathrm{GaCl}_{4}\right]$ (Ref. 9). Similarly, oxidation of indium powder with benzoyl peroxide produced the first example of a mononuclear eight-coordinate indium (III) benzoate, $\mathrm{In}\left(\eta^{2}-\mathrm{O}_{2} \mathrm{CC}_{6} \mathrm{H}_{5}\right)_{3}\left(4-\mathrm{MeC}_{5} \mathrm{H}_{5} \mathrm{~N}\right)_{2}$ (Ref. 10). In this report, we detail two further examples of structurally characterized examples of mixed-ligand chelated-benzoato complexes prepared by this straightforward synthetic approach with classical ligands. We discuss the structures and compare them to other molecular and metal-organic framework structures of indium and gallium.

\subsection{Experimental}

\subsection{Materials and Methods}

All manipulations were performed either in an MBRAUN Labmaster 130 drybox or utilizing standard Schlenk techniques under an atmosphere of nitrogen. All solvents were distilled from sodium benzophenone ketyl just prior to use. Celite was purchased from ACROS and heated under vacuum for $24 \mathrm{hr}$ prior to use. All glassware used was flame-dried and stored in an oven prior to use. Solutions were transferred via stainless steel cannulae and/or syringes. Gallium (II) chloride ( 99.999 percent) and indium (I) chloride (99.995 percent) (both from Alfa Aesar) were purchased in argon-filled ampoules and transferred in an inert atmosphere glove box. Benzoyl peroxide $\left(\left(\mathrm{C}_{6} \mathrm{H}_{5} \mathrm{CO}_{2}\right)_{2}\right.$ - Aldrich $)$ was deaerated under vacuum at room temperature prior to use.

\subsection{Preparation of $\left[\mathrm{GaCl}_{2}(4-\mathrm{Mepy})_{2}\left(\mathrm{O}_{2} \mathrm{CPh}\right)\right] \cdot 4-\mathrm{Mepy}(1)$}

Gallium (II) chloride ( $0.302 \mathrm{~g}, 0.996 \mathrm{mmol})$ and a 2:1 excess of benzoyl peroxide $(0.480 \mathrm{~g}$, $1.98 \mathrm{mmol}$ ) were added to a Schlenk flask charged with a stirbar in a drybox. The flask was sealed with a septum, removed from the drybox, and taken to a fume hood where the flask was placed under nitrogen. 4-methylpyridine $(10 \mathrm{~mL})$ was slowly added via cannula with rapid stirring. The solution immediately turned a deep crimson red color and the solution was allowed to stir at room temperature for $48 \mathrm{hr}$. During the course of the reaction, the solution gradually changed from crimson red to orange in color. The reaction mixture was then filtered through a pad of Celite. An equal amount of hexanes was layered on the filtrate via cannula. Colorless single crystals, suitable for x-ray diffraction studies were observed at the solvent interface after standing for $72 \mathrm{hr}$ at room temperature.

\subsection{Preparation of [ $\left.\mathrm{InCl}(4-\mathrm{Mepy})_{2}\left(\mathrm{O}_{2} \mathrm{CPh}\right)_{2}\right] \cdot 4-\mathrm{Mepy}(2)$}

Indium (I) chloride $(0.150 \mathrm{~g}, 0.998 \mathrm{mmol})$ and benzoyl peroxide $(0.240 \mathrm{~g}, 0.998 \mathrm{mmol})$ were added to a Schlenk flask charged with a stirbar in a drybox. The flask was sealed with a septum, removed from the drybox and taken to a fume hood where the reaction flask was placed under nitrogen. 4-methylpyridine $(10 \mathrm{~mL})$ was slowly added via cannula with rapid stirring, and a cloudy solution was evident. The solution was allowed to stir for 7 days at room temperature. The reaction mixture was filtered through a pad of Celite to yield a colorless solution. An equal amount of hexanes was layered on the filtrate via cannula. Colorless single crystals, suitable for $\mathrm{x}$-ray diffraction studies were isolated from the resulting filtrate after standing for 3 weeks at room temperature. 


\subsection{X-Ray Crystallographic Study of 1 and 2}

$\mathrm{X}$-ray intensity data from previously described single crystals were measured at $300 \mathrm{~K}$ on a Bruker SMART1000 (Bruker AXS, Inc.) CCD-based x-ray diffractometer system using Mo $\operatorname{Ko}(\lambda=0.71073 \AA$ ). Crystals used for data collection were cemented to a quartz fiber with epoxy glue. Data were measured using $\omega$ scans of $0.3^{\circ}$ per frame for 10 seconds for both $\mathbf{1}$ and $\mathbf{2}$ so that a hemisphere (1271 frames) was collected with a final resolution of $0.75 \AA$. No decay was indicated by the recollection of the first 50 frames at the end of data collection. The frames were integrated with the Bruker SAINT (Bruker AXS, Inc.) software package (Ref. 11) using a narrow-frame integration algorithm, which also corrects for the Lorentz and polarization effects. Absorption corrections were applied using SADABS (Refs. 12 and 13) supplied by George Sheldrick (Ref. 14). Structures were solved and refined using the Bruker SHELXTL (Bruker AXS, Inc.) (version 5.1) software package (Refs. 14 and 15) in space groups of $P$-1bar (1) and $P 2_{1} / n$ (2). All non-hydrogen atoms were derived from the direct method solution. With all non-hydrogen atoms being anisotropic and hydrogen atoms being isotropic, the structure was refined to convergence by least squares method on $\mathrm{F}^{2}$, SHELXL-97, incorporated in SHELXTL.PC V 5.03 (Ref. 14).

Crystallographic data are given in Table 1, selected bond lengths and angles are given in Table 2.

TABLE 1.-SUMMARY OF X-RAY DIFFRACTION DATA

\begin{tabular}{|c|c|c|}
\hline Compound & 1 & 2 \\
\hline Empirical Formula & $\mathrm{C}_{25} \mathrm{H}_{26} \mathrm{Cl}_{2} \mathrm{GaN}_{3} \mathrm{O}_{2}$ & $\mathrm{C}_{32} \mathrm{H}_{31} \mathrm{ClInN}_{3} \mathrm{O}_{4}$ \\
\hline Molecular Weight & 541.11 & 671.87 \\
\hline Crystal System & Triclinic & Monoclinic \\
\hline Space Group & $P$-1(bar) (No. 2) & $P 2_{1} / n$ (No. 14$)$ \\
\hline $\mathrm{a}, \AA$ & $10.5987(13)$ & $13.1565(13)$ \\
\hline $\mathrm{b}, \AA$ & $11.3705(15)$ & $8.2116(8)$ \\
\hline $\mathrm{c}, \AA$ & $12.6660(17)$ & $28.796(3)$ \\
\hline$\alpha$, deg. & $104.525(2)$ & 90 \\
\hline$\beta$, deg. & $101.976(3)$ & $94.460(2)$ \\
\hline$\gamma$, deg. & $111.981(2)$ & 90 \\
\hline $\mathrm{V}, \AA^{3}$ & $1290.7(3)$ & $3101.6(5)$ \\
\hline Z & 2 & 4 \\
\hline $\mathrm{D}_{\text {calc }}, \mathrm{g} \mathrm{cm}^{-3}$ & 1.392 & 1.439 \\
\hline$\mu, \mathrm{mm}^{-1}$ & 1.30 & 0.89 \\
\hline$\tilde{E}$ & 556 & 1368 \\
\hline Crystal size, $\mathrm{mm}$ & 0.38 by 0.23 by 0.09 & 0.31 by 0.14 by 0.08 \\
\hline$\theta$ range for collection, deg. & 2.2 to 22.3 & 2.5 to 22.2 \\
\hline No. collected & 6882 & 15267 \\
\hline No. ind. $\left(\mathrm{R}_{\text {int }}\right)$ & $4505(0.029)$ & $5462(0.054)$ \\
\hline $\mathrm{T}_{\max }, \mathrm{T}_{\min }$ & $1.000,0.537$ & $1.000,0.580$ \\
\hline$R\left[F^{2}>2 \sigma\left(F^{2}\right)\right]$ & 0.044 & 0.053 \\
\hline$w R\left(F^{2}\right)$ & $0.084^{\mathrm{a}}$ & $0.119^{\mathrm{b}}$ \\
\hline Largest diff. peak and hole, e $\AA^{-3}$ & $0.48,-0.41$ & $1.17,-0.47$ \\
\hline Goodness of fit (GOF) on $F^{2}$ & 1.000 & 0.999 \\
\hline CCDC deposit no. & 753437 & 753438 \\
\hline
\end{tabular}

${ }^{\mathrm{a}} w=1 /\left[\sigma^{2}\left(F_{\mathrm{o}}^{2}\right)+(0.0202 P)^{2}\right]$, where $P=\left(F_{\mathrm{o}}{ }^{2}+2 F_{\mathrm{c}}{ }^{2}\right) / 3$

${ }^{\mathrm{b}} w=1 /\left[\sigma^{2}\left(F_{\mathrm{o}}^{2}\right)+(0.0584 P)^{2}\right]$, where $P=\left(F_{\mathrm{o}}{ }^{2}+2 F_{\mathrm{c}}{ }^{2}\right) / 3$. 
TABLE 2.- SELECT BOND DISTANCE $(\AA)$ AND ANGLES $\left({ }^{\circ}\right)$ FOR COMPOUNDS 1 AND 2

\begin{tabular}{|c|c|c|c|}
\hline $\mathrm{Ga}(1)-\mathrm{O}(1)$ & $2.099(2)$ & $\operatorname{In}(1)-O(1)$ & $2.274(3)$ \\
\hline \multirow[t]{3}{*}{$\mathrm{Ga}(1)-\mathrm{O}(2)$} & $2.102(3)$ & $\operatorname{In}(1)-O(2)$ & $2.292(4)$ \\
\hline & & $\operatorname{In}(1)-\mathrm{O}(3)$ & $2.212(3)$ \\
\hline & & $\operatorname{In}(1)-\mathrm{O}(4)$ & $2.417(4)$ \\
\hline $\mathrm{Ga}(1)-\mathrm{N}(1)$ & $2.099(3)$ & $\operatorname{In}(1)-\mathrm{N}(1)$ & $2.312(4)$ \\
\hline $\mathrm{Ga}(1)-\mathrm{N}(2)$ & 2.111(3) & $\operatorname{In}(1)-N(2)$ & $2.286(4)$ \\
\hline $\mathrm{Ga}(1)-\mathrm{Cl}(1)$ & $2.2455(11)$ & $\operatorname{In}(1)-\mathrm{Cl}(2)$ & $2.4132(15)$ \\
\hline $\mathrm{Ga}(1)-\mathrm{Cl}(2)$ & $2.2365(11)$ & $\mathrm{O}(1)-\mathrm{C}(13)$ & $1.261(6)$ \\
\hline $\mathrm{O}(1)-\mathrm{C}(1)$ & $1.288(4)$ & $\mathrm{O}(2)-\mathrm{C}(13)$ & $1.259(6)$ \\
\hline \multirow[t]{2}{*}{$\mathrm{O}(2)-\mathrm{C}(1)$} & $1.271(4)$ & $\mathrm{O}(3)-\mathrm{C}(20)$ & $1.248(6)$ \\
\hline & & $\mathrm{O}(4)-\mathrm{C}(20)$ & $1.249(6)$ \\
\hline $\mathrm{O}(1)-\mathrm{Ga}(1)-\mathrm{N}(1)$ & $85.47(10)$ & $\mathrm{O}(3)-\operatorname{In}(1)-\mathrm{O}(1)$ & $162.40(15)$ \\
\hline $\mathrm{O}(1)-\mathrm{Ga}(1)-\mathrm{O}(2)$ & $62.83(10)$ & $\mathrm{O}(3)-\operatorname{In}(1)-\mathrm{N}(2)$ & $82.98(14)$ \\
\hline $\mathrm{N}(1)-\mathrm{Ga}(1)-\mathrm{O}(2)$ & $87.21(11)$ & $\mathrm{O}(1)-\operatorname{In}(1)-\mathrm{N}(2)$ & $83.94(14)$ \\
\hline $\mathrm{O}(1)-\mathrm{Ga}(1)-\mathrm{N}(2)$ & $86.64(11)$ & $\mathrm{O}(3)-\operatorname{In}(1)-\mathrm{O}(2)$ & $134.10(14)$ \\
\hline $\mathrm{N}(1)-\mathrm{Ga}(1)-\mathrm{N}(2)$ & $171.04(12)$ & $\mathrm{O}(1)-\operatorname{In}(1)-\mathrm{O}(2)$ & $56.99(12)$ \\
\hline $\mathrm{O}(2)-\mathrm{Ga}(1)-\mathrm{N}(2)$ & $85.43(11)$ & $\mathrm{N}(2)-\operatorname{In}(1)-\mathrm{O}(2)$ & $140.78(14)$ \\
\hline $\mathrm{O}(1)-\mathrm{Ga}(1)-\mathrm{Cl}(2)$ & $159.73(8)$ & $\mathrm{O}(3)-\operatorname{In}(1)-\mathrm{N}(1)$ & $86.83(14)$ \\
\hline $\mathrm{N}(1)-\mathrm{Ga}(1)-\mathrm{Cl}(2)$ & $93.01(9)$ & $\mathrm{O}(1)-\operatorname{In}(1)-\mathrm{N}(1)$ & $81.50(14)$ \\
\hline $\mathrm{O}(2)-\mathrm{Ga}(1)-\mathrm{Cl}(2)$ & $96.92(8)$ & $\mathrm{N}(2)-\operatorname{In}(1)-\mathrm{N}(1)$ & $90.28(15)$ \\
\hline $\mathrm{N}(2)-\mathrm{Ga}(1)-\mathrm{Cl}(2)$ & $92.92(10)$ & $\mathrm{O}(2)-\operatorname{In}(1)-\mathrm{N}(1)$ & $81.33(14)$ \\
\hline $\mathrm{O}(1)-\mathrm{Ga}(1)-\mathrm{Cl}(1)$ & $95.30(8)$ & $\mathrm{O}(3)-\operatorname{In}(1)-\mathrm{Cl}(2)$ & $97.07(11)$ \\
\hline $\mathrm{N}(1)-\mathrm{Ga}(1)-\mathrm{Cl}(1)$ & $92.62(10)$ & $\mathrm{O}(1)-\operatorname{In}(1)-\mathrm{Cl}(2)$ & $95.43(11)$ \\
\hline $\mathrm{O}(2)-\mathrm{Ga}(1)-\mathrm{Cl}(1)$ & $158.09(8)$ & $\mathrm{N}(2)-\operatorname{In}(1)-\mathrm{Cl}(2)$ & $93.44(11)$ \\
\hline $\mathrm{N}(2)-\mathrm{Ga}(1)-\mathrm{Cl}(1)$ & $92.32(10)$ & $\mathrm{O}(2)-\operatorname{In}(1)-\mathrm{Cl}(2)$ & $93.60(10)$ \\
\hline $\mathrm{Cl}(2)-\mathrm{Ga}(1)-\mathrm{Cl}(1)$ & $104.96(4)$ & $\mathrm{N}(1)-\operatorname{In}(1)-\mathrm{Cl}(2)$ & 174.91(10) \\
\hline \multirow[t]{8}{*}{$\mathrm{O}(2)-\mathrm{C}(1)-\mathrm{O}(1)$} & $117.6(4)$ & $\mathrm{O}(3)-\operatorname{In}(1)-\mathrm{O}(4)$ & $55.57(13)$ \\
\hline & & $\mathrm{O}(1)-\operatorname{In}(1)-\mathrm{O}(4)$ & $135.57(13)$ \\
\hline & & $\mathrm{N}(2)-\operatorname{In}(1)-\mathrm{O}(4)$ & $138.45(14)$ \\
\hline & & $\mathrm{O}(2)-\operatorname{In}(1)-\mathrm{O}(4)$ & $79.23(13)$ \\
\hline & & $\mathrm{N}(1)-\operatorname{In}(1)-\mathrm{O}(4)$ & $85.11(14)$ \\
\hline & & $\mathrm{Cl}(2)-\operatorname{In}(1)-\mathrm{O}(4)$ & $94.37(10)$ \\
\hline & & $\mathrm{O}(2)-\mathrm{C}(13)-\mathrm{O}(1)$ & $119.6(5)$ \\
\hline & & $\mathrm{O}(4)-\mathrm{C}(20)-\mathrm{O}(3)$ & $120.2(5)$ \\
\hline
\end{tabular}

\subsection{Results and Discus0sion}

\subsection{Synthesis of Compounds 1 and 2}

The synthesis of both compound $\mathbf{1}$ and $\mathbf{2}$ can be simply described as oxidative addition, see (1) and (2) respectively, below, with the cleavage of the peroxide bond and subsequent electron transfer producing benzoate ligands and oxidizing the In and Ga centers to produce trivalent metal complexes.

$$
\begin{aligned}
& \mathrm{Ga}_{2} \mathrm{Cl}_{4}+\mathrm{H}_{5} \mathrm{C} 6 \mathrm{C}(\mathrm{O}) \mathrm{O}-\mathrm{OC}(\mathrm{O}) \mathrm{C}_{6} \mathrm{H}_{5} \\
& \mathrm{InCl}+\mathrm{H}_{5} \mathrm{C}_{6} \mathrm{C}(\mathrm{O}) \mathrm{O} \text {-OCC(O) } \mathrm{CaCl}_{6} \mathrm{H}_{5} \rightarrow \mathrm{InCl}(4-\mathrm{Mepy})_{2}\left(\mathrm{O}_{2} \mathrm{CC}_{6} \mathrm{H}_{5}\right) \\
& \mathrm{Inepy}_{2}\left(\mathrm{O}_{2} \mathrm{CC}_{6} \mathrm{H}_{5}\right)_{2}
\end{aligned}
$$

The starting material for reaction (1) is actually more accurately described as a $\mathrm{Ga}(\mathrm{I}) \mathrm{Ga}(\mathrm{III})$ species: $\mathrm{Ga}^{+}\left[\mathrm{GaCl}_{4}\right]^{-}$. The reaction most likely proceeds through an intermediate ethane-like formally $\mathrm{Ga}(\mathrm{II})$ complex, $\mathrm{Ga}_{2} \mathrm{Cl}_{4}(\gamma \text {-pic })_{2}$ (3). An unsuccessful attempt to produce a gallium basic carboxylate (Ref. 9), resulted in the isolation and structural characterization of the Ga(II) dimer (Ref. 7). In the same study, an 
attempt to produce a mixed-metal Ga-Ni species resulted in the isolation of the solvated mixed-oxidation state salt, $\left[\mathrm{GaCl}_{2}(\gamma \text {-pic) })_{4}\right]^{+}\left[\mathrm{GaCl}_{4}\right]^{-}$(4) (Ref. 7). The isolation and structural characterization of $\mathbf{1}$ brings to five the number of related structures from the reaction of benzoate-containing reagents and $\mathrm{Ga}_{2} \mathrm{Cl}_{4}$ in $\gamma$ picoline, reinforcing the utility of $\mathrm{Ga}_{2} \mathrm{Cl}_{4}$ as an extremely versatile entry into Ga coordination chemistry.

The oxidizing potential of benzoyl peroxide is amply demonstrated in reaction (2). We had previously exploited this chemistry when we prepared the first example of an eight-coordinate indium benzoate, $\mathrm{In}\left(\mathrm{O}_{2} \mathrm{CC}_{6} \mathrm{H}_{5}\right)_{3}(4-\mathrm{Mepy})_{2}$, by oxidation of indium metal powder with a 3:2 excess of benzoyl peroxide in $\gamma$ picoline (Ref. 10). The use of the indium (I) chloride starting material provides a site for further chemistry to be utilized for preparation of mixed-metal complexes or clusters (Refs. 5 and 6).

\subsection{Structural Features of Compound 1}

A key structural feature of $\mathbf{1}$ is the chelating benzoate ligand; compound $\mathbf{1}$ (shown in Fig. 1) is the first example of such a structurally characterized gallium benzoate. A recent review of mononuclear sixcoordinated Ga compounds did not include a single example of a homoleptic, tris-bidentate or chelating carboxylate structure (Ref. 16). A structural and theoretical study by Barron et al. demonstrated that chelated-group 13 carboxylate structures (particularly $\mathrm{Al}$ ) are not energetically favorable, relative to bridged on mono-dentate coordination (Ref. 17). A very thorough discussion of coordination of metal carboxylates can be found in a classic monograph (Ref. 18).

The angle formed by the chelating benzoate in $1, \mathrm{O} 1-\mathrm{Ga}-\mathrm{O} 2$, is $62.83(10)^{\circ}$, and is significantly larger than the average angle for compound 2 of $56.28(13)^{\circ}$ but is comparable to an average angle of $62.6(1)^{\circ}$ for three structurally characterized chelating carboxylates previously reported (Refs. 19 to 21); a more thorough consideration of indium carboxylate-chelate bonding angles is given below. The previously reported chelating carboxylates include a four-coordinate doubly-chelating dicarboxylate organometallic complex (Ref. 19) and two compounds stabilized by chelating hetrocyclic ligands, one with (pyrazolyl)borate (Ref. 20) and the other with benzoxazole (Ref. 21).

Previously, we prepared a trimeric basic carboxylate (compound 5) with syn-syn bridging benzoates (Ref. 18) obtained through a similar reaction involving sodium benzoate instead of benzoyl peroxide (Ref. 9); see reaction (3). The source of the central oxygen atom is likely water from the sodium benzoate.

$$
2 \mathrm{Ga}_{2} \mathrm{Cl}_{4}+6 \mathrm{NaCO}_{2} \mathrm{C}_{6} \mathrm{H}_{5} \rightarrow\left[\mathrm{Ga}_{3}\left(\mu_{3}-\mathrm{O}\right)\left(\mu-\mathrm{O}_{2} \mathrm{CC}_{6} \mathrm{H}_{5}\right)_{6}(4-\mathrm{Mepy})_{3}\right]\left[\mathrm{GaCl}_{4}\right]
$$

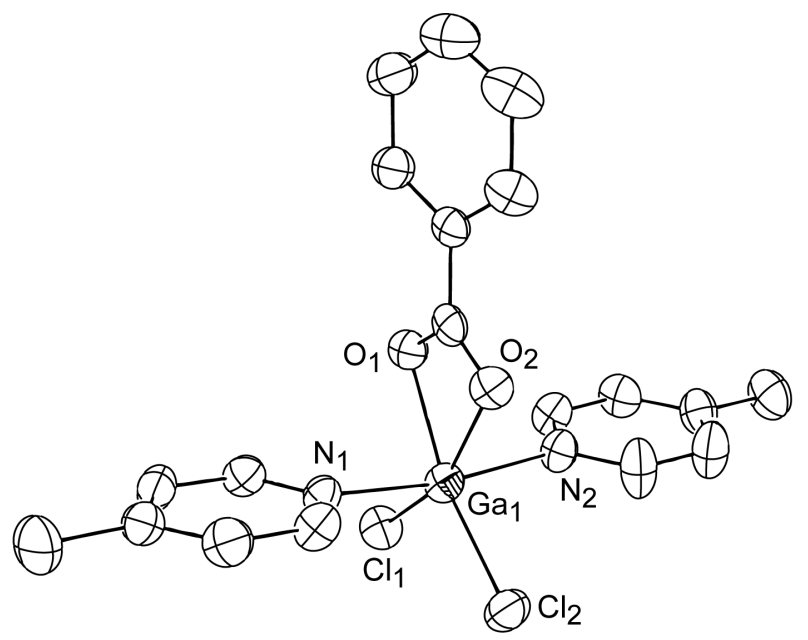

Figure 1.-ORTEP diagram and atomic labeling scheme of first coordination sphere of $\left[\mathrm{GaCl}_{2}\left(\mathrm{O}_{2} \mathrm{CPh}\right)(4-\mathrm{Mepy})_{2}\right] \cdot 4-$ Mepy (1) (hydrogen atoms and the co-crystallized picoline not shown for clarity). 
The Ga-O bond distances of the bridging benzoates in 5 ranged from 1.959 (5) to 2.006 (9) $\AA$, with an average distance of 1.985(6) $\AA$ (Ref. 9). This is shorter than the average Ga-O bond distance for the chelating benzoate found in $\mathbf{1}$ of 2.101(3) $\AA$. These intermolecular distances are comparable to those found in the three chelating carboxylates (Refs. 19 to 21) that range from 2.042(2) to 2.127(3) $\AA$, with the fourcoordinate organometallic compound having the shortest average bond length (2.049(2) $\AA$ ) (Ref. 19). Of the four structurally characterized chelating gallium carboxylates, only the (pyrazolyl) borate compound had asymmetrical coordination of the carboxylate moiety $(\Delta \mathrm{Ga}-\mathrm{O}=0.079(3) \AA)$ (Ref. 20).

This can be contrasted to the surprisingly complex structure of methylgallium diacetate, $\mathrm{H}_{3} \mathrm{C}$ $\mathrm{Ga}\left(\mathrm{O}_{2} \mathrm{CCH}_{3}\right)_{2}$ (Ref. 22). This structure includes dative, bridging, and monodentate acetate coordination resulting in Ga-O bond distances ranging from 1.873(3) to 2.219(3) Å. As noted previously (Ref. 17), several reports of related organometallic indium compounds, dimethyl (Ref. 23) and diethyl (Ref. 24) acetate include simultaneously bridging and chelating acetate coordination. A much more straightforward $\mathrm{Ga}$ acetate monodentate interaction is found in a neutral acetato tetraphenylporphyrin complex $(\mathrm{Ga}(\mathrm{OAc})(\mathrm{tpp})$ with Ga-O bond length of 1.874(4) $\AA$ (Ref. 25), very similar to the mondentate Ga-O bond length of 1.873(3) ̊̊ (Ref. 22).

A further example of a lengthened $\mathrm{M}-\mathrm{O}$ bond for a chelating versus bridging carboxylate group is demonstrated by a series of silver complexes $\left(\mathrm{AgO}_{2} \mathrm{CR}\right)_{2}$ where a dimer $(\mathrm{R}=\mathrm{C}(\mathrm{Me})=\mathrm{C}(\mathrm{Me}) \mathrm{H})$ with bridging carboxylates is stabilized as a monomer by the addition of triphenylphosphine ligands: $\left[\mathrm{AgO}_{2} \mathrm{CR}\left(\mathrm{PPh}_{3}\right)_{2}\right]\left(\mathrm{R}=\mathrm{CH}_{2} \mathrm{CN}, \mathrm{CH}_{2} \mathrm{CH}_{2}=\mathrm{C}(\mathrm{H}) \mathrm{CH}_{2}\right.$, and $\left.\mathrm{C}(\mathrm{Me})=\mathrm{C}(\mathrm{Me}) \mathrm{H}\right)$ with a subsequent average increase of 0.235(3) $\AA$ for a chelated versus bridging Ag-O bond length (Ref. 26).

The carboxylate moiety in 1 is fairly symmetrical with an average C-O bond length of 1.280(4) $\AA$. This is comparable to an average C-O bond length of 1.274(5) $\AA$ for the bridging acetates of methylgalliumdiacetate (Ref. 22), 1.25(2) $\AA$ for the bridging benzoates of compound 5 (Ref. 9), 1.255(2) $\AA$ for the chelating acetate of the benzoxazole (Ref. 21), and 1.254(6) $\AA$ for compound 2 of this study. A recent study of solvent-free synthesis of a bismuth carboxylate reported a C-O bond range of 1.249(2) $\AA$ to 1.301(2) $\AA$ for dimeric substituted benzoates with multiple coordination modes (Ref. 27).

The 2.105(3) $\AA$ average Ga-N bond length for the ligated picolines is comparable to 2.105(5) $\AA$ for 4 (Ref. 7) and 2.085(9) $\AA$ for 5 (Ref. 9). This is slightly longer than Ga-N bond length of 2.058(4) $\AA$ for the (pyrazolyl)borate (Ref. 20) and 2.034(2) $\AA$ for the benzoxazole (Ref. 21) compounds. It is longer than the Ga-N (picoline) bond length of 2.005 (6) $\AA$ of the Ga(II) complex, 3 (Ref. 7). Finally, the Ga-Cl average bond length of 2.2410(11) $\AA$ is comparable to Ga-Cl bond lengths determined for compounds 3 (2.195(2)

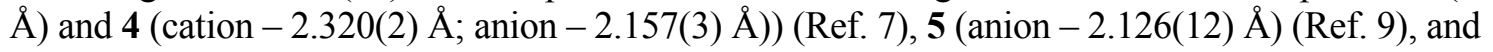
2.2827(16) $\AA$ averaged for $\left[\mathrm{GaCl}_{2}(\gamma \text {-pic })_{2}\left(\mathrm{~S}_{2} \mathrm{CNR}_{2}\right)\right](\mathrm{R}=\mathrm{Me}(\operatorname{Ref} .8), \mathrm{Et}(\operatorname{Ref} .7))$.

The N1-Ga-N2 angle is $171.04(12)^{\circ}$; as expected the picoline rings tilt towards the chelated benzoate. The three aromatic rings are roughly parallel; giving the complex a semi-paddlewheel appearance, more typically associated with bridging carboxylate structures (Refs. 9 and 28). The narrow angle of the benzoate results in a larger $\mathrm{Cl} 2-\mathrm{Ga}-\mathrm{Cl} 1$ angle of $104.96(4)^{\circ}$. The $\mathrm{O} 2-\mathrm{C} 1-\mathrm{O} 1$ angle of $117.6(4)^{\circ}$ is slightly smaller than the $120^{\circ}$ expected for an $\mathrm{sp}^{2}$ hybridized $\mathrm{RCO}_{2}^{-}$moiety; this is likely due to the steric hindrance of the chelated benzoate bonding to a $\mathrm{Ga}(\mathrm{III})$ center. For the less-constrained six bridging benzoates in complex $\mathbf{5}$, the $\mathrm{CO}_{2}{ }^{-}$angle ranged from $123^{\circ}$ to $128^{\circ}$ (Ref. 9). In $\mathrm{CH}_{3} \mathrm{Ga}(\mathrm{OAc})_{2}$, the average bridging $\mathrm{CO}_{2}{ }^{-}$bonding angle was $120.3(3)^{\circ}$; the monodentate acetate had a $122.0(5)^{\circ} \mathrm{CO}_{2}^{-}$bonding angle (Ref. 19); and the monodentate acetate of $\left(\mathrm{Ga}(\mathrm{OAc})(\mathrm{tpp})\right.$ had a $122.9(5)^{\circ} \mathrm{CO}_{2}^{-}$bonding angle (Ref. 22). The other chelating carboxylates (Refs. 19 and 21) had more narrow O-C-O angles of approximately $118^{\circ}$, expected for the wider O-Ga-O chelate.

\subsection{Structural Features of Compound 2}

As has been noted previously, bidentate chelating In (III) carboxylate bonding has not frequently been observed (Refs. 17 and 18). Compound 2 (shown in Fig. 2) had In-O bond distances ranging from 2.212(3) $\AA$ to 2.417(4) $\AA$ with one symmetrical benzoate, like complex 1, with an average In-O distance of 2.283(4) $\AA$, the other unsymmetrical with a $0.205 \AA \Delta \mathrm{In}-\mathrm{O}$ bond length. A review of In-O bond lengths in 
chelating In carboxylates exhibits a range from 2.142(5) to $2.875(8) \AA \AA$ from (nearly) symmetrical to asymmetrical (Refs. 4, 10, 29 to 36). In our previously reported eight-coordinate In benzoate complex, one benzoate was symmetrical with an In-O bond distance of 2.286(5) $\AA$, and the other two were asymmetrical with distances of 2.225(6) $\AA$ and 2.413(5) $\AA$ (Ref. 10). Asymmetrical bonding of chelating carboxylate groups to an $\operatorname{In}(\mathrm{III})$ center has been observed for other eight-coordinate carboxylates: $\operatorname{In}\left(\mathrm{O}_{2} \mathrm{CMe}\right)_{3} \mathrm{~L}(\mathrm{~L}=$ phen, $\Delta \mathrm{In}-\mathrm{O}=0.157(7) \AA$ and $0.198(7) \AA ; \mathrm{L}=$ bipy, $\Delta \mathrm{In}-\mathrm{O}=0.172(6) \AA$ ) (Ref. 37). A related but simpler, cis-dichloro chelating-benzoato octahedral complex with two trans pyridine ligands had similar, nearly symmetrical In-O bond lengths of 2.246(4) $\AA$ and 2.280(4) $\AA$ (Ref. 32). Another octahedral benzoate compound with a tetradentate $\mathrm{N}_{2} \mathrm{~S}_{2}$ bis(aminoethanethiol) chelate had a significantly more asymmetric benzoate coordination with In-O bond lengths of 2.247(3) $\AA$ and 2.390(3) $\AA$ (Ref. 30). Another sevencoordinate carboxylate with a terpyridine and two azide ligands had a slightly less asymmetric carboxylate with In-O bond lengths of 2.274(2) $\AA$ and 2.354(2) $\AA$ (Ref. 4). A similar degree of asymmetry is observed for a series of trinuclear and tetranuclear metal cluster butyrates containing In, and Co or Ni atoms (Ref. 31).

An unsymmetrical acetate is found in a (TPP) $\operatorname{In}\left(\mathrm{O}_{2} \mathrm{CCH}_{3}\right)(\mathrm{TPP}=$ tetraphenylporphinato) complex with In-O bond lengths of 2.215(4) $\AA$ and 2.322(4) $\AA$ (Ref. 33). A pair of related tetra-arylporphyrinato indium acetates (TRP) $\operatorname{In}\left(\mathrm{O}_{2} \mathrm{CCH}_{3}\right)(\mathrm{R}=\mathrm{py}$, 4-pyridyl; mp, 4-methoxyphenyl) resulted in nearly symmetrical $(\mathrm{R}=$ py, In-O range from 2.24(1) to 2.34(1) $\AA$ ) and unsymmetrical $(\mathrm{R}=\mathrm{mp}, \mathrm{In}-\mathrm{O}=2.185(6) \AA$ and $2.412(6) \AA)$ acetates (Ref. 34). An asymmetrically-bound acetate is also found in an (OEP) $\operatorname{In}\left(\mathrm{O}_{2} \mathrm{CCH}_{3}\right)(\mathrm{OEP}=$ octaethylporphyrinato) complex with In-O bond lengths of 2.60(2) $\AA$ and 2.14(1) $\AA$ (Ref. 35). Two related ylide-containing halide compounds had In-O coordination that varied from slightly $(<0.1 \AA)$ to moderately asymmetric (>0.25 $\AA$ ) (Ref. 29). Finally, the most asymmetric bidentate chelate is found in a dimeric $\mu$-oxo bridged neutral seven-coordinate complex $\left[\mathrm{L}_{2} \mathrm{In}_{2}\left(\mathrm{CH}_{3} \mathrm{CO}_{2}\right)_{4}(\mu-\mathrm{O})\right] \cdot 2 \mathrm{NaClO} 4(\mathrm{~L}=1,4,7$-triazacyclononane $)$ with each $\mathrm{In}(\mathrm{III})$ bound to a monodentate and chelating acetate group; significantly different average In-O bond lengths in the chelating groups of 2.142(5) $\AA$ and 2.863(7) $\AA$ (Ref. 36) are present.

The In-Cl bond length in $\mathbf{2}$ is 2.4132(15) $\AA$ and similar to the related octahedral chloro-benzoato compound, 2.391(2) $\AA$ (Ref. 32). It is also comparable to the cis-In-Cl bond length in $m e r-\mathrm{InCl}_{3}(4 \text {-Etpy) })_{3}$ of $2.41 \AA$ but shorter than the trans-In-Cl bond length of $2.46 \AA$ (Ref. 38). The cis- (2.471(1) $\AA$ ) and trans $(2.476(2) \AA)$ In- $\mathrm{Cl}$ bond lengths in $m e r-\mathrm{InCl}_{3}(\text { py) })_{3} \bullet$ py (Ref. 39) are practically equal within experimental error. The ylide compound with chloride ligands has an In-Cl bond length that ranges from 2.26(1) to 2.49(1) $\AA$ (Ref. 29).

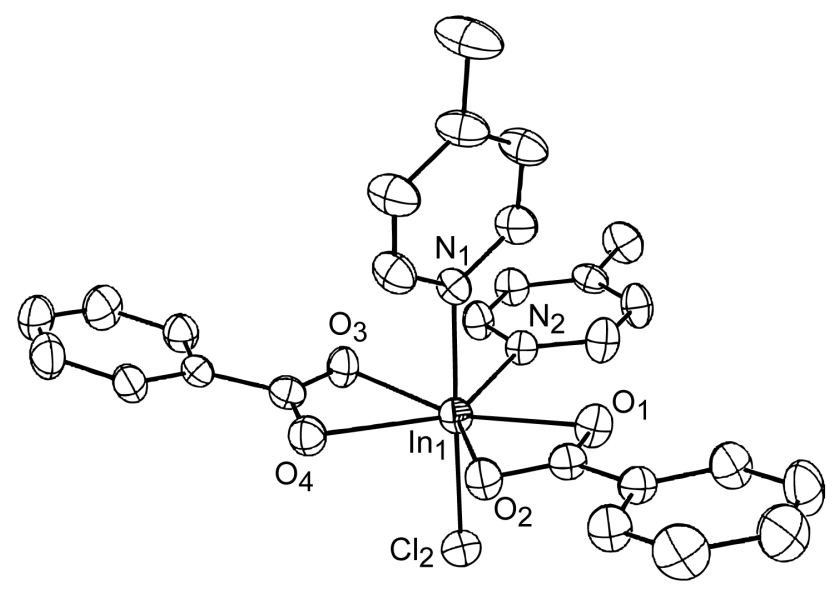

Figure 2.-ORTEP diagram and atomic labeling scheme of first coordination sphere of $\left[\mathrm{InCl}\left(\mathrm{O}_{2} \mathrm{CPh}\right)_{2}(4-\mathrm{Mepy})_{2}\right] \cdot 4-$ Mepy (2) (hydrogen atoms and the co-crystallized picoline not shown for clarity). 
The In-N bond lengths are unremarkable but slightly unsymmetrical; there is a slight lengthening of the In-N bond trans to the $\mathrm{Cl}(2.312(4) \AA$ versus 2.286(4) $\AA$ in the plane). The two In-N bond lengths for the trans pyridines in the related octahedral compound are (2.250(5) and 2.300(6) $\AA$ (Ref. 32). This is typically not observed in the family of $m e r-\operatorname{InX}{ }_{3}(\mathrm{Rpy})_{3}(\mathrm{R}=\mathrm{H}, \mathrm{X}=\mathrm{I}, \mathrm{Br} ; \mathrm{R}=\mathrm{Et} ; \mathrm{X}=\mathrm{Cl} ; \mathrm{R}=\mathrm{Me}, \mathrm{X}=\mathrm{I})$ complexes where the average In-N bond length is $2.31 \AA$ (Refs. 38 to 41 ). There is some asymmetry in mer$\mathrm{InCl}_{3}(\mathrm{py})_{3} \cdot$ py where there is a some lengthening of the In-N bond trans to a $\mathrm{Cl}(2.377(21) \AA)$ versus 2.302(7) $\AA$ (for trans pyridines). The In-N bond lengths were similar for the two seven-coordinate compounds with terpyridine $(2.292(2)-2.341(2) \AA)$ and azide (2.203(3) $\AA$ ) ligands (Ref. 4) and the triazacyclononane chelate (2.271(5) to 2.324(5) $\AA$ ) (Ref. 36). The tetradentate bis(aminoethanethiol) octahedral compound (2.298(3) and 2.367(3) $\AA$ ) was also similar (Ref. 30). The In-N bond lengths for the porphyrin compounds were shorter and ranged from 2.16 to $2.18 \AA$ (Refs. 33 to 35 ).

The $\mathrm{Cl}(2)-\operatorname{In}(1)-\mathrm{N}(1)$ bond angle is $174.91(10)^{\circ}$, the apical $\mathrm{Cl}$ atom is inclined away from the other five coordinated atoms in the $\mathrm{InO}_{4} \mathrm{~N}$ plane at angles from $93.44(11)^{\circ}(\mathrm{N}(2)-\operatorname{In}(1)-\mathrm{Cl}(2))$ to $97.07(11)^{\circ}(\mathrm{O}(3)-$ $\mathrm{In}(1)-\mathrm{Cl}(2))$. The two In- $\mathrm{N}$ bonds are nearly perpendicular forming a $\left(\mathrm{N}(2)-\operatorname{In}(1)-\mathrm{N}(1)\right.$ angle of $90.28(15)^{\circ}$. The four In-O bonds are bent towards the apical N(1) forming O-In(1)-N(1) angles that vary from an average of $81.42(14)^{\circ}$ for $\mathrm{In}-\mathrm{O}(1)$ and $\mathrm{In}-\mathrm{O}(2)$ to $86.83(14)^{\circ}$ for $\mathrm{In}-\mathrm{O}(3)$. Steric factors can be invoked to explain this structural feature. As with the gallium complex above, the two chelating benzoates and the apical picoline are roughly parallel and form a semi-paddlewheel structure.

The benzoate chelates contain smaller angles of $56.99(12)^{\circ}$ and $55.57(13)^{\circ}$ for $(\mathrm{O}(1)-\operatorname{In}(1)-\mathrm{O}(2))$ and $(\mathrm{O}(3)-\operatorname{In}(1)-\mathrm{O}(4))$, respectively in the indium complex (2) than the gallium complexes (1) and (Refs. 19 to 21). The individual nearest-neighbor atoms in the $\mathrm{InO}_{4} \mathrm{~N}$ plane form five angles that add up to approximately $359^{\circ}$; the non-chelated atoms form average angles of $82^{\circ}$. The larger size of the In(III) center results in less steric strain for the chelates and a nearly symmetrical $\mathrm{RCO}_{2}{ }^{-}$average bond angle of $119.9(5)^{\circ}$. The closely-related eight-coordinate tris-benzoato bis-picoline indium (III) complex had quite similar O-In$\mathrm{O}$ angles of 56.5(3) ${ }^{\circ}$ and 55.9(2) ${ }^{\circ}$ (Ref. 10). The eight-coordinate complex also had a nearly symmetrical $\mathrm{RCO}_{2}^{-}$average bond angle of $119.5(8)^{\circ}$. The octahedral benzoato complex, isostructural with compound $\mathbf{1}$, had a similar $\mathrm{RCO}_{2}^{-}$angle $\left(118.9(6)^{\circ}\right)$, with a wider O-In-O angle of 57.5(1) ${ }^{\circ}$ (Ref. 32), similar to the larger of the two angles of compound 2 , but significantly less than the O-Ga-O angle of $62.83(10)^{\circ}$ of 1 . With a few exceptions, the O-In-O benzoate angle ranged from a low of 55.57(13) to 56.99(12) for many of the six, seven, or eight-coordinate carboxylates. The six-coordinate porphyrin acetate compounds had slightly smaller average O-In-O (54.6(3) $)^{\circ}$ and $\mathrm{RCO}_{2}{ }^{-}\left(118.5(4)^{\circ}\right)$ angles (Refs. 33 and 34). The dimeric $\mu$-oxo bridged neutral seven-coordinate complex $\left[\mathrm{L}_{2} \mathrm{In}_{2}\left(\mathrm{CH}_{3} \mathrm{CO}_{2}\right)_{4}(\mu-\mathrm{O})\right] \cdot 2 \mathrm{NaClO} 4(\mathrm{~L}=1,4,7$-triazacyclononane $)$ with asymmetric chelating acetate groups had a significantly constrained O-In-O bond angle of $48.9(2)^{\circ}$. The smaller O-In-O angle with the porphyrin-containing structures is expected as the macrocycles impose steric strain. The ylide compounds (Ref. 29) and the multi-nuclear cluster compounds (Ref. 31) had larger bond angles ranging from around $57^{\circ}$ to $59^{\circ}$.

As noted above and compiled in Table 3, there are nearly 15 chelated In(III) carboxylate or related molecular structures that are five (Ref. 29) six (Refs. 29 to 36), seven (2 and (Refs. 4, 31, and 36)), and eight (Refs. 10 and 37) coordinate. Many of these chelating carboxylate structures consist of a macrocyclic or large heterocyclic chelating ligand (Refs. 4, 30, 33 to 36) or multi-nuclear cluster structure (Ref. 31). It is reasonable to assert that the aromatic benzoato chelate and pyridine-like ligands (Refs. 10 and 32), electronwithdrawing halide ligands (2, (Refs. 29 and 32)) and solvent of crystallization (2, (Ref. 10) stabilize the structures in a similar fashion without undue steric hindrance. Two other macrocycle-stabilized structures of seven-coordinate $\mathrm{In}(\mathrm{III})$ to note are two related pentagonal bipyramid complexes, $\left[\mathrm{InCl}_{3}\left(\mathrm{~L}^{\prime}\right)(\mathrm{MeOH})\right]$ and $\left[\mathrm{InCl}\left(\eta^{2}-\mathrm{C}_{2} \mathrm{O}_{4}\right)\left(\mathrm{L}^{\prime}\right)\left(\mathrm{OH}_{2}\right)\right]\left(\mathrm{L}^{\prime}=2,6\right.$-bis(acetyloxime)-pyridine) (Refs. 42 and 43). A final observation to make is that compounds $\mathbf{1}$ and $\mathbf{2}$ adopt a roughly pentagonal bipyramidal structure. Compound $\mathbf{1}$, and the isostructural In complex (Ref. 32), can be described as semi-paddlewheel with three roughly parallel aromatic rings. The semi-paddlewheel motif of compound $\mathbf{2}$ has a more propeller-like appearance with a bowl-shaped triple aromatic-ring coordination plane. 
TABLE 3.--SELECTED BOND DISTANCES $(\AA)$ AND ANGLES $\left(^{\circ}\right)$ FOR MOLECULAR COMPLEXES WITH CHELATING CARBOXYLATES OF Ga, In AND OTHER METALS WITH SIMILAR IONIC RADII

\begin{tabular}{|c|c|c|c|c|c|}
\hline Compound & $\mathrm{CN}$ & $\begin{array}{c}\mathrm{d}_{\mathrm{M}-\mathrm{O}} \\
(\AA)\end{array}$ & $\begin{array}{l}\mathrm{O}-\mathrm{M}-\mathrm{O} \\
\left({ }^{\circ}\right)\end{array}$ & $\begin{array}{l}\mathrm{O}-\mathrm{C}-\mathrm{O} \\
\left({ }^{\circ}\right)\end{array}$ & Reference \\
\hline $\begin{array}{l}{\left[\mathrm{Ag}\left(\mathrm{O}_{2} \mathrm{CR}\right)\left(\mathrm{P}\left(\mathrm{C}_{6} \mathrm{H}_{5}\right)_{3}\right)_{2}\right]} \\
\mathrm{R}=\mathrm{CH}_{2} \mathrm{CN},\left(\mathrm{CH}_{2}\right)_{2} \mathrm{CH}=\mathrm{CH}_{2} \text {, or } \mathrm{C}(\mathrm{Me})=\mathrm{C}(\mathrm{H}) \mathrm{Me}\end{array}$ & 4 & $2.401(3)-2.495(2)$ & $52.61(7)-53.86(6)$ & $122.6(2)-126.4(3)$ & Ref. 26 \\
\hline $\begin{array}{l}{\left[\left(\mathrm{Ga}\left(\left(\mathrm{Me}_{3} \mathrm{Si}\right)_{2} \mathrm{CH}\right)_{2}\right)_{2}(\mathrm{ndc})\right] \cdot 2 \mathrm{MeC}_{5} \mathrm{H}_{9}} \\
\mathrm{H}_{2} \mathrm{ndc}=1,6 \text {-naphthalenedicarboxylic acid }\end{array}$ & 4 & $2.042(2), 2.056(2)$ & $64.53(8)$ & $118.0(3)$ & Ref. 19 \\
\hline$\left[\mathrm{InCl}_{3}\left(\eta 2-\mathrm{O}_{2} \mathrm{CC}\left\{\mathrm{P}\left(\mathrm{C}_{6} \mathrm{H}_{5}\right)_{3}\right\}_{2}\right]\right.$ & 5 & $2.181(6), 2.304(6)$ & $58.7(2)$ & $118.6(8)$ & Ref. 29 \\
\hline$\left[\mathrm{InI}_{2}\left(\eta 2-\mathrm{O}_{2} \mathrm{CC}\left\{\mathrm{P}\left(\mathrm{C}_{6} \mathrm{H}_{5}\right)_{3}\right\}_{2}{ }^{+}\right]\left[\mathrm{I}^{-}\right]\right.$ & 6 & $2.168(5)-2.437(5)$ & $57.0(2), 58.6(2)$ & $117.9(7), 120.1(7)$ & Ref. 29 \\
\hline $\begin{array}{l}{\left[\mathrm{H}_{2} \mathrm{~B}(\mathrm{pz})_{2}\right]_{2} \mathrm{Ga}\left(\mathrm{O}_{2} \mathrm{CCH}_{3}\right)} \\
\mathrm{pz}=\left\{\mathrm{N}_{2}(\mathrm{CH})_{3}\right\}\end{array}$ & 6 & $2.048(3), 2.127(3)$ & $62.3(1)$ & & Ref. 20 \\
\hline $\begin{array}{l}{\left[\mathrm{Ga}(\mathrm{hbo})_{2}\left(\mathrm{O}_{2} \mathrm{CCH}_{3}\right)\right]} \\
\text { Hhbo =2-(2'-hydroxyphenyl)-2-benzoxazole }\end{array}$ & 6 & $2.117(2)$ & $61.1(1)$ & $118.2(4)$ & Ref. 21 \\
\hline$\left[\mathrm{GaCl}_{2}\left(\mathrm{O}_{2} \mathrm{CPh}\right)(4-\mathrm{Mepy})_{2}\right] \bullet 4-\mathrm{Mepy}$ & 6 & $2.099(2), 2.102(3)$ & $62.83(10)$ & $117.6(4)$ & This work \\
\hline $\begin{array}{l}{\left[\mathrm{In}(\mathrm{BAT}-\mathrm{TM})\left(\mathrm{O}_{2} \mathrm{CC}_{6} \mathrm{H}_{5}\right)\right]} \\
\text { BAT-TM }=\mathrm{N}_{2} \mathrm{~S}_{2} \text { tetradentate ligand } \\
\end{array}$ & 6 & $2.247(3), 2.390(3)$ & $56.3(1)$ & $120.7(4)$ & Ref. 30 \\
\hline $\begin{array}{l}{\left[\mathrm{In}_{2} \mathrm{M}_{2}(\mathrm{OH})_{2}\left(\mathrm{O}_{2} \mathrm{C}^{\mathrm{t}} \mathrm{Bu}\right)_{8} \mathrm{~L}_{2}\right]^{\mathrm{a}}} \\
\left(\mathrm{M}, \mathrm{L}=\mathrm{Co}, \mathrm{MeCN} ; \mathrm{M}, \mathrm{L}=\mathrm{Ni}, \mathrm{MeCN} / \mathrm{HO}_{2} \mathrm{C}^{\mathrm{t}} \mathrm{Bu}\right)\end{array}$ & 6 & $2.2091(13)-2.275(8)$ & $56.9(3)-59.1(3)$ & $117.1(10)-120.6(10)$ & Ref. 31 \\
\hline$\left[\mathrm{InCl}_{2}\left(\mathrm{O}_{2} \mathrm{CPh}\right)(\mathrm{py})_{2}\right]$ & 6 & $2.246(4), 2.280(4)$ & $57.5(1)$ & $118.9(6)$ & Ref. 32 \\
\hline $\begin{array}{l}{\left[\mathrm{In}(\mathrm{TPP})\left(\mathrm{O}_{2} \mathrm{CCH}_{3}\right)\right]} \\
\mathrm{TPP}=\text { tetraphenylporphyrin }\end{array}$ & 6 & $2.215(4), 2.322(4)$ & $54.4(2)$ & $118.5(4)$ & Ref. 33 \\
\hline $\begin{array}{l}{\left[\mathrm{In}(\mathrm{TRP})\left(\mathrm{O}_{2} \mathrm{CCH}_{3}\right)\right]} \\
\mathrm{R}=4 \text {-pyridyl or 4-methoxyphenyl }\end{array}$ & 6 & $2.185(6)-2.412(6)$ & $54.4(4), 55.0(2)$ & $115(2)-121.1(7)$ & Ref. 34 \\
\hline$\left[\mathrm{InCl}\left(\mathrm{O}_{2} \mathrm{CPh}\right)_{2}(4-\mathrm{Mepy})_{2}\right] \bullet(4-\mathrm{Mepy})$ & 7 & $2.212(3)-2.417(4)$ & $\begin{array}{l}55.57(13) \\
56.99(12) \\
\end{array}$ & $119.6(5), 120.2(5)$ & This work \\
\hline $\begin{array}{l}{\left[\mathrm{L}_{2} \mathrm{In}_{2}\left(\mathrm{O}_{2} \mathrm{CCH}_{3}\right)_{4}(\mu-\mathrm{O})\right] \cdot 2 \mathrm{NaClO}_{4}} \\
\mathrm{~L}=1,4,7 \text {-triazacyclononane }\end{array}$ & 7 & $2.142(5)-2.875(8)$ & $48.9(2)$ & & Ref. 36 \\
\hline $\begin{array}{l}{\left[\mathrm{In}_{2} \mathrm{Ni}(\mathrm{OH})\left(\mathrm{O}_{2} \mathrm{C}^{\mathrm{t}} \mathrm{Bu}\right)_{7}\left(\mathrm{HO}_{2} \mathrm{C}^{\mathrm{t}} \mathrm{Bu}\right)_{x}\right]^{\mathrm{a}}} \\
(x=1,2)\end{array}$ & 7 & $2.208(6)-2.249(6)$ & $\begin{array}{l}58.4(2) \\
58.5(2)\end{array}$ & $\begin{array}{l}118.6(8) \\
119.0(8)\end{array}$ & Ref. 31 \\
\hline $\begin{array}{l}{\left[(\text { terpy }) \operatorname{In}\left(\mathrm{N}_{3}\right)_{2}\left(\mathrm{O}_{2} \mathrm{C}\left(\mathrm{CH}_{2}\right)_{2} \mathrm{CH}_{2} \mathrm{OH}\right)\right]} \\
\text { terpy }=\text { terpyridine }\end{array}$ & 7 & $2.274(2), 2.354(2)$ & $56.31(7)$ & $120.2(2)$ & Ref. 4 \\
\hline$\left[\mathrm{SbCl}\left(\mathrm{C}_{6} \mathrm{H}_{5}\right)_{2}\left(\mathrm{O}_{2} \mathrm{C}(2-\mathrm{Me}) \mathrm{C}_{6} \mathrm{H}_{4}\right)_{2}\right]$ & 7 & $2.213(3)-2.296(3)$ & $57.46(11), 57.58(11)$ & $118.8(6), 120.5(7)$ & Ref. 44 \\
\hline$\left[\mathrm{Cd}\left(\mathrm{O}_{2} \mathrm{C}(3,4-\mathrm{OH}) \mathrm{C}_{6} \mathrm{H}_{3}\right)_{2}\left(\mathrm{H}_{2} \mathrm{O}\right)_{3}\right]$ & 7 & $2.304(4)-2.513(4)$ & $54.0(1), 54.3(1)$ & 117.3(4), 117.6(4), & Ref. 45 \\
\hline 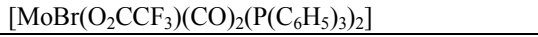 & 7 & $2.304(9), 2.320(9)$ & $56.5(3)$ & $126.0(1)$ & Ref. 46 \\
\hline$\left[\mathrm{Bi}\left(\mathrm{O}_{2} \mathrm{C}(2-\mathrm{EtO}) \mathrm{C}_{6} \mathrm{H}_{4}\right)_{3}\right]_{2}$ & 8 & $2.207(1), 2.532(1)$ & $55.06(4)$ & $120.2(2)$ & Ref. 27 \\
\hline$\left[\mathrm{In}\left(\mathrm{O}_{2} \mathrm{CPh}\right)_{3}(4-\mathrm{Mepy})_{2}\right] \bullet 4 \mathrm{H}_{2} \mathrm{O}$ & 8 & $2.225(6)-2.413(5)$ & $55.9(2), 56.5(3)$ & $119(1), 120.0(7)$ & Ref. 10 \\
\hline $\begin{array}{l}{\left[\mathrm{In}\left(\mathrm{O}_{2} \mathrm{CCH}_{3}\right)_{3} \mathrm{~L}\right]} \\
\mathrm{L}=2,2^{\prime} \text {-bipy or } 1,10 \text {-phen }\end{array}$ & 8 & $2.221(3)-2.422(6)$ & $54.4(2)-56.5(3)$ & & Ref. 37 \\
\hline
\end{tabular}

\subsection{Comparison of Compounds 1 and 2 with Similar Molecular Complexes of Other Metals}

It is interesting to include a survey of other related chelating-carboxylate complexes of other metals similar in size to In(III) ions. Table 3 includes compounds $\mathbf{1}$ and 2, other related indium and gallium structures, and other related structures of mostly main group complexes with higher coordination numbers and similar ionic radii $(0.8 \sim 0.92 \AA)$ to $\operatorname{In}(\mathrm{III})$ complexes. A key feature of nearly every compound in Table 3 is complexation with aromatic rings for electronic and steric stability. These chelating compounds rely on a variety of motifs for supporting the chelating structure: macrocyclic and/or multi-dentate ligands (Refs. 4, 10, 19 to 21, 26,30, 33 to 37), carboxylates with unsaturated bonds or pendant groups for structural or electronic stabilization (Refs. 4, 26, 27, 29, 44, and 45), or electronic-withdrawing ligands such as halides and $\mathrm{CF}_{3} \mathrm{CO}_{2}^{-}(\mathbf{1}, \mathbf{2}$, (Refs. 29, 32, 37, 38, and 46)). Interestingly, several structures contained multiple modes of coordination to identical carboxylate groups (Refs. 27 and 31).

The structure most similar to compound $\mathbf{1}$ is the analogous six-coordinate In benzoate complex (Ref. 32). However, due to the larger size of the In(III) ion, this structure does not contain as much strain around the chelating benzoate. The seven-coordinate $\mathrm{Sb}(\mathrm{V})$ organometallic compound is most similar in structure to 2 (Ref. 44). The other structurally-characterized seven-coordinate In(III) carboxylate environments are sterically constrained by tri-dentate chelating ligands (Refs. 4 and 36) or a multi-nuclear cluster environment (Ref. 31). Apparently, electron-withdrawing chloride ligand(s) and the inherent stability of the semi-paddlewheel 
structure of the aromatic rings enables the use of simpler ligands via a straightforward synthesis used to produce compounds $\mathbf{1}$ and $\mathbf{2}$ and the related octahedral indium complex (Ref. 27).

\subsection{Comparison of Molecular Indium Benzoates with Indium Coordination Polymers}

While a slight departure from the major thrust of this paper, it is useful to include a brief survey of recently reported chelating-carboxylate indium coordination polymers (Refs. 47 to 61), part of a recent wave of a literature describing intriguing new hybrid organic-inorganic materials with many potential applications. Table 4 includes numerous examples of indium carboxylate polymer framework materials and seven- and eight-coordinate indium benzoates from this study (compound 2) and Reference 10, respectively. Table 4 includes five basic types of In polymers constructs: seven-coordinate In polymers from di- (Refs. 47 to 49), tri- (Refs. 50 to 53) and tetracarboxylates (Ref. 54 and 55) and eight-coordinate In polymers from di- (Refs. 56 to 59) and tricarboxylates (Refs. 60 and 61), several of which are chiral (Refs. 51, 58, and 59).

TABLE 4.--SELECTED BOND DISTANCES $(\AA ̊)$ AND ANGLES $\left(^{\circ}\right)$ FOR INDIUM COORDINATION POLYMERS AND MOLECULAR BENZOATES

\begin{tabular}{|c|c|c|c|c|c|}
\hline Compound & $\mathrm{CN}$ & $\begin{array}{c}\mathrm{d}_{\mathrm{M}-\mathrm{O}} \\
(\AA)\end{array}$ & $\begin{array}{l}\mathrm{O}-\mathrm{M}-\mathrm{O} \\
\left({ }^{\circ}\right)\end{array}$ & $\begin{array}{c}\mathrm{O}-\mathrm{C}-\mathrm{O} \\
\left({ }^{\circ}\right)\end{array}$ & Reference \\
\hline$\left[\mathrm{InCl}\left(\mathrm{O}_{2} \mathrm{CPh}\right)_{2}(4-\mathrm{Mepy})_{2}\right] \bullet(4-\mathrm{Mepy})$ & 7 & $2.212(3)-2.417(4)$ & $55.57(13), 56.99(12)$ & $119.6(5), 120.2(5)$ & This work \\
\hline $\begin{array}{l}{\left[\mathrm{In}(\mathrm{OH})(\mathrm{ndc})_{2}\left(\mathrm{H}_{2} \mathrm{O}\right)\right]_{n}} \\
\mathrm{H}_{2} \mathrm{ndc}=2,6-\text { or } 2,7 \text {-naphthalenedicarboxylic acid }\end{array}$ & 7 & $2.247(2)-2.3458(18)$ & $56.39(12), 58.00(8)$ & $119.1(2), 119.5(3)$ & Ref. 47 \\
\hline $\begin{array}{l}\left.\left[\mathrm{In}_{2} \mathrm{OH}\right)_{2}(\mathrm{pdc})_{2}\left(\mathrm{H}_{2} \mathrm{O}\right)\right]_{n} \\
\mathrm{H}_{2} \text { pdc }=3,5 \text {-pyridinedicarboxylic acid }\end{array}$ & 7 & $2.255(2), 2.311(2)$ & $57.53(5)$ & $121.36(18)$ & Ref. 48 \\
\hline $\begin{array}{l}{\left[\mathrm{In}(\mathrm{OH})(\mathrm{tca})\left(\mathrm{H}_{2} \mathrm{O}\right)\right]_{n}} \\
\mathrm{H}_{2} \mathrm{tca}=\text { thiophene-2,5-dicarboxylic acid }\end{array}$ & 7 & $2.209(2)-2.391(2)$ & $56.86(7), 57.53(7)$ & $119.8(2), 120.2(2)$ & Ref. 49 \\
\hline $\begin{array}{l}\left\{\left[\mathrm{Hbipy}^{+}\right]\left[\mathrm{In}(\mathrm{Hbtc})_{2}(\text { bipy })^{-}\right] \bullet 0.5 \mathrm{H}_{2} \mathrm{O}\right\}_{n} \\
\mathrm{H}_{3} \text { btc }=\text { benzenetricarboxylic acid } \\
\text { bipy }=4,4^{\prime} \text { '-bipyridine }\end{array}$ & 7 & $2.208(4)-2.360(5)$ & $54.4(4), 55.0(2)$ & $\begin{array}{l}120.1(6) \\
120.3(6)\end{array}$ & Ref. 50 \\
\hline $\begin{array}{l}\left\{\left[\mathrm{Hpy}^{+}\right]_{2}\left[\operatorname{In}_{2}(\mathrm{btc})_{2}(\mu-\mathrm{OH})_{2}{ }^{2-}\right]\right\}_{n} \\
\mathrm{H}_{3} \text { btc }=\text { benzenetricarboxylic acid } \\
\text { py = pyridine }\end{array}$ & 7 & $2.140(11)-2.569(10)$ & $54.8(3)-57.1(4)$ & $119.5(13)-124.1(14)$ & Ref. 51 \\
\hline $\begin{array}{l}\left\{\left[\operatorname{In}_{2}(\text { btc })_{2}(\text { bipy })_{2}\right] \bullet 4 \mathrm{H}_{2} \mathrm{O}\right\}_{n} \\
\mathrm{H}_{3} \text { btc }=\text { benzenetricarboxylic acid } \\
\text { bipy }=2,2 \text { '-bipyridine }\end{array}$ & 7 & $2.170(4)-2.434(4)$ & $56.06(13), 56.38(12)$ & $119.4(5), 120.4(5)$ & Ref. 52 \\
\hline $\begin{array}{l}\left\{\left[\mathrm{In}_{2}(\mathrm{btc})_{2}\left(\mathrm{H}_{2} \mathrm{O}\right)_{2}\right] \cdot 2 \mathrm{H}_{2} \mathrm{O}\right\}_{n} \\
\mathrm{H}_{3} \text { btc }=\text { benzenetricarboxylic acid }\end{array}$ & 7 & $2.575(2), 2.580(2)$ & $56.75(11), 58.10(11)$ & $119.4(4), 119.8(4)$ & Ref. 53 \\
\hline $\begin{array}{l}{\left[\mathrm{In}_{2}(\mathrm{btec})(\text { bipy })_{2} \mathrm{Cl}_{2}\right]_{n}} \\
\mathrm{H}_{4} \text { btec }=\text { benzenetetracarboxylic acid } \\
\text { bipy }=2,2 \text { '-bipyridine }\end{array}$ & 7 & $2.176(8)-2.551(9)$ & $54.7(2)-57.5(2)$ & $118.8(7)-122.3(11)$ & $\begin{array}{l}\text { Refs. } 54 \\
\text { and } 55\end{array}$ \\
\hline$\left[\mathrm{In}\left(\mathrm{O}_{2} \mathrm{CPh}\right)_{3}(4-\mathrm{Mepy})_{2}\right] \cdot 4 \mathrm{H}_{2} \mathrm{O}$ & 8 & $2.225(6)-2.413(5)$ & $55.9(2), 56.5(3)$ & $119(1), 120.0(7)$ & Ref. 10 \\
\hline $\begin{array}{l}\left\{\left[\mathrm{H}^{+}\right]\left[\operatorname{In}(\mathrm{bdc})_{2}\right]\right\}_{n} \\
\mathrm{H}_{2} \text { bdc = benzenedicarboxylic acid }\end{array}$ & 8 & $2.267(7), 2.283(7)$ & $57.7(3)$ & $120.8(9)$ & Ref. 56 \\
\hline $\begin{array}{l}\left\{\left[\mathrm{M}\left(\mathrm{H}_{2} \mathrm{O}\right)_{6}{ }^{3+}\right]\left[\operatorname{In}_{3}\left(\mu_{2}-\mathrm{pdc}\right)_{6}{ }^{3-}\right] \cdot 15 \mathrm{H}_{2} \mathrm{O}\right\}_{n} \\
\mathrm{H}_{2} \text { pdc }=2,3-\text { pyrazinedicarboxylic acid } \\
\mathrm{M}=\mathrm{In}, \mathrm{Cr}_{0.7} \operatorname{In}_{0.3}, \text { or } \mathrm{Fe}_{0.3} \operatorname{In}_{0.7}\end{array}$ & 8 & $2.236(4)-2.446(6)$ & $54.9(2)-55.4(3)$ & $120.3(5)-123.4(8)$ & Ref. 57 \\
\hline $\begin{array}{l}\left\{\left[(\mathrm{Htmdp})^{+}\right]\left[\mathrm{In}(\mathrm{pdc})_{2}{ }^{-}\right] \cdot(\text { EtOH })\left(\mathrm{H}_{2} \mathrm{O}\right)_{2}\right\}_{n} \\
\text { tmdp }=4,4^{\prime} \text {-trimethylenedipiperidine } \\
\mathrm{H}_{2} \mathrm{pdc}=2,5 \text {-pyridinedicarboxylic acid }\end{array}$ & 8 & $2.205(5), 2.588(5)$ & $54.29(17)$ & $122.5(7)$ & Ref. 58 \\
\hline $\begin{array}{l}\left\{\left[\mathrm{NR}_{4}{ }^{+}\right]\left[\mathrm{In}(\mathrm{DL}-\mathrm{cam})_{2}{ }^{-}\right] \cdot\left(\mathrm{H}_{2} \mathrm{O}\right)_{2}\right\}_{n} \\
\mathrm{R}=\mathrm{CH}_{3} ; \mathrm{D} \text { - and L-camphorate } \\
\mathrm{NR}_{4}^{+}=\text {choline; D-camphorate }\end{array}$ & 8 & $2.188(7)-2.407(8)$ & $55.4(3)-57.3(3)$ & $119.0(10)-120.7(9)$ & Ref. 59 \\
\hline $\begin{array}{l}{ }^{\mathrm{a}}\left\{\left[\mathrm{NR}_{4}{ }^{+}\right]\left[\mathrm{In}(\mathrm{DL}-\mathrm{cam})_{2}^{-}\right] \cdot\left(\mathrm{H}_{2} \mathrm{O}\right)_{2}\right\}_{n} \\
\mathrm{R}=n \text {-propyl; D- or DL-camphorate } \\
\mathrm{NR}_{4}{ }^{+}=\text {imidizolium; D-camphorate }\end{array}$ & 8 & $2.163(3)-2.481(3)$ & $54.7(4)-58.2(4)$ & $117(2)-124.8(16)$ & Ref. 60 \\
\hline $\begin{array}{l}{\left[\operatorname{In}(\text { btc })_{1.5}(\text { bipy })\right]_{n}} \\
\mathrm{H}_{3} \text { btc }=1,4 \text {-benzenetricarboxylic acid } \\
\text { bipy }=2,2 \text { '-bipyridine }\end{array}$ & 8 & $2.204(3)-2.551(4)$ & $53.50(11)-57.22(10)$ & $120.1(4), 120.5(4)$ & Ref. 61 \\
\hline $\begin{array}{l}\left\{\left[\mathrm{H}_{2} \operatorname{tmdp}^{2+}\right]_{3}\left[\operatorname{In}_{6}(\mathrm{btc})_{8}{ }^{6-}\right] \bullet 40 \mathrm{H}_{2} \mathrm{O}\right\}_{n} \\
\text { tmdp }=4,4 \text { '-trimethylene dipiperidine } \\
\mathrm{H}_{3} \text { btc }=\text { benzenetricarboxylic acid }\end{array}$ & 8 & $2.155(5)-2.409(5)$ & $56.36(18)$ & $120.3(6)$ & Ref. 62 \\
\hline
\end{tabular}

${ }^{\mathrm{a}}$ Table entry also includes three more related structures (total of six) from same publication. 
The most notable observation to make when viewing the relevant bond distances and angles of the polymer materials as compared to the respective molecular species is the striking similarity of the In coordination environments; this is expected due to a lack of steric strain around In atoms from the flexible polymer coordination environment, it is this flexibility that gives rise to a variety of intriguing $2-\mathrm{D}$ and 3-D structural features. The In-O bond distances and $\mathrm{O}-\mathrm{In}-\mathrm{O}$ and $\mathrm{O}-\mathrm{C}-\mathrm{O}$ carboxylate angles of the polymer materials are quite similar to the molecular benzoates.

\subsection{Conclusion}

In summary, we have prepared two new simple chelating benzoate complexes of gallium and indium by straightforward oxidation of the $\mathrm{Ga}(\mathrm{II})$ and $\mathrm{In}(\mathrm{I})$ chlorides by benzoyl peroxide in 4-methylpyridine at room temperature. The six-coordinate gallium complex, which also includes two chloride and two gpicoline ligands, is the first example of a structurally-characterized chelating gallium benzoate. It is isostructural with a previously characterized analagous In(III) benzoate complex. The seven-coordinate In(III) bis-benzoate also includes one chloride and two g-picoline ligands and is the first example of its type with a simple ligand set; it is a structural analogue to a seven-coordinate $\mathrm{Sb}(\mathrm{V})$ organometallic compound. The most striking feature of these surprisingly simple compounds is a semi-paddlewheel geometry of roughly parallel aromatic rings of the benzoate and picoline ligands, which seems to lend an enhanced stability to the solid-state structures. This stability is further demonstrated by the similarity of the metal coordination environment for a number of seven or eight-coordinate indium carboxylate coordination polymer materials.

\section{References}

1. K.K. Banger and A.F. Hepp, in Encyclopedia of Inorganic Chemistry, $2^{\text {nd }}$ Edition, Editor-in-Chief: R. Bruce King, Volume III, John Wiley \& Sons, Ltd., Chichester, England (2005) pp. 1589-1621.

2. D. Fan, M. Afzaal, M.A. Malik, C.Q. Nguyen, P. O'Brien, P.J. Thomas, Coord. Chem. Rev. 251 (2007) pp. 1878-1888.

3. D.G. Hehemann, J.E. Lau, J.D. Harris, M.D. Hoops, N.V. Duffy, P.E. Fanwick, O. Khan, M.H.-C. Jin, A.F. Hepp, Mater. Sci. Eng. B 116 (2005) pp. 381-389.

4. R.A. Fischer, H. Sussek, H. Parala, H. Pritzkow, J. Organomet. Chem. 592 (1999) pp. 205-211.

5. A.F. Hepp, K.K. Banger, M.H.-C. Jin, J.D. Harris, J.S. McNatt, J.E. Dickman, in Solution Processing of Inorganic Materials, Editor: David B. Mitzi, John Wiley \& Sons, Inc., Hoboken, NJ (2009) pp. 157-198.

6. K.K. Banger, M.H.-C. Jin, J.D. Harris, P.E. Fanwick, A.F. Hepp, Inorg. Chem. 42 (2003) pp. $7713-$ 7715.

7. E.M. Gordon, A.F. Hepp, S.A. Duraj, T.S. Habash, P.E. Fanwick, J.D. Schupp, W.E. Eckles, S. Long, Inorg. Chim. Acta 257 (1997) pp. 247-251.

8. X. Zhou, M.L. Breen, S.A. Duraj, A.F. Hepp, Main Group Metal Chemistry 22 (1999) pp. 35-39.

9. M.T. Andras, S.A. Duraj, A.F. Hepp, P.E. Fanwick, M.M. Bodnar, J. Am. Chem. Soc. 114 (1992) pp. 786-787.

10. M.T. Andras, A.F. Hepp, E.B. Clark, D.A. Scheiman, S.A. Duraj, P.E. Fanwick, Inorg. Chem. 32 (1993) pp. 4150-4152.

11. SAINT V 6.035, Bruker-AXS Inc.: Madison, WI, 1999.

12. SADABS V 2.03, Bruker-AXS Inc.: Madison, WI, 2002.

13. R.H. Blessing, Acta Cryst. A51 (1995) pp. 33-38.

14. G.M. Sheldrick, Acta Cryst. A64 (2008) pp. 112-122.

15. SHELXTL 5.03 (WINDOW-NT Version), Bruker-AXS Inc.: Madison,WI, 1998.

16. G. Bandoli, A. Dolmella, F. Tisato, M. Porchia, F. Refosco, Coord. Chem. Rev. 253 (2009) pp. 56-77. 
17. C.E. Bethley, C.L. Aitken, C.J. Harlan, Y. Koide, S.G. Bott, and A.R. Barron, Organometallics 16 (1997) pp. 329-341.

18. R.C. Mehrotra and B. Bohra, Metal Carboxylates, Academic Press, London, England (1983) pp. 11-15.

19. W. Uhl, A.-C. Fick, T. Spies, G. Geiseler, K. Harms, Organometallics 23 (2004) pp. 72-75.

20. D.L. Reger, S.J. Knox, L. Lebioda, Organometallics 9 (1990) pp. 2218-2222.

21. H.R. Hoveyda, S.J. Rettig, C. Orvig, Inorg. Chem. 32 (1993) pp. 4909-4913.

22. H.D. Hausen, K. Sille, J. Weidlein, W. Schwarz, J. Organomet. Chem. 160 (1978) pp. 411-419.

23. F.W.B. Einstein, M.M. Gilbert, D.G. Tuck, J. Chem. Soc., Dalton Trans. (1973) pp. 248-251.

24. H.-D. Hausen, J. Organomet. Chem. 39 (1972) pp. C37-C40.

25. Y.-Y. Hsieh, Y.-H. Sheu, I-C. Liu, C.-C. Lin, J.-H. Chen, S.-S. Wang, H.-J. Lin, J. Chem. Crystal. 26 (1996) pp. 203-207.

26. D.A. Edwards, M.F. Mahon, K.C. Molloy, V. Ogrodnik, J. Mater. Chem. 13 (2003) pp. 563-570.

27. P.C. Andrews, G.B. Deacon, P.C. Junk, I. Kumar, and M. Silberstein, J. Chem. Soc., Dalton Trans. (2006) pp. 4852-4858.

28. S.I. Vagin, A.K. Ott, B. Rieger, Chem. Ing. Tech. 79 (2007) pp. 767-779.

29. W. Petz, K. Köhler, P. Mörschel, B. Neumüller, Z. Anorg. Allg. Chem. 631 (2005) pp. 1779-1784.

30. Y.Y. Zheng, S. Saluja, G.P.A. Yap, M. Blumenstein, A.L. Rheingold, L.C. Francesconi, Inorg. Chem. 35 (1996) pp. 6656-6666.

31. E.C. Sañudo, C.A. Muryn, M.A. Helliwell, G.A. Timco, W. Wernsdorfer, R.E.P. Winpenny, J. Chem. Soc., Chem. Commun. (2007) pp. 801-803.

32. M.A. Khan, C. Peppe, D.G. Tuck, Acta. Cryst. C 39 (1983) pp. 1339-1342.

33. S.-J. Lin, T.-N. Hong, J.-Y. Tung, J.-H. Chen, Inorg. Chem. 36 (1997) 3886-3891.

34. T.-N. Hong, Y.-H. Sheu, K.-H. Jang, J.-H. Chen, S.-S. Wang, J.-H. Wang, S.-L. Wang, Polyhedron 15 (1996) 2647-2654.

35. P. Cocolios, R. Guilard, D. Bayeul, C. Lecomte, Inorg. Chem. 24 (1985) pp. 2058-2062.

36. K. Weighardt, M. Kleine-Boymann, B. Nuber, J. Weiss, Inorg. Chem. 25 (1986) pp. 1654-1659.

37. H. Preut and F. Huber, Z. Anorg. Allg. Chem. 450 (1979) pp. 120-130.

38. M. Green, S. Norager, P. Moriarity, M. Motevalli, P. O’Brien, J. Mater. Chem. 10 (2000) pp. 1939-1943.

39. S.E. Jeffs, R.W.H. Small, I.J. Worrall, Acta. Cryst. C 40 (1984) pp. 1329-1331.

40. M.A. Brown and D.G. Tuck, Inorg. Chim. Acta. 247 (1996) pp. 135-138.

41. J.A.J. Pardoe, A.R. Cowley, A.J. Downs, T.M. Greene, Acta. Cryst. C 61 (2005) pp. m200-m202.

42. S. Abram, C. Maichle-Mossmer, U. Abram, Polyhedron 16 (1997) pp. 2183-2191.

43. S. Abram, C. Maichle-Mossmer, U. Abram, Polyhedron 16 (1997) pp. 2291-2298.

44. K.C.K. Swamy, M.A. Said, and M. Netaji, J. Chem. Cryst. 29 (1999) pp. 1103-1106.

45. V. Aletras, N. Hadjiliadis, D. Stabaki, A. Karaliota, M. Kamariotaki, I. Butler, J.C. Plakatouras, S. Perlepes, Polyhedron 16 (1997) pp. 1399-1402.

46. B.J. Brisdon, A.G.W. Hodson, M.F. Mahon, K.C. Molloy, J. Chem. Soc., Dalton Trans. (1993) pp. 245-251.

47. M. Vougo-Zanda, X. Wang, A.J. Jacobson, Inorg. Chem. 46 (2007) pp. 8819-8824.

48. Z. Guo, Y. Li, W. Yuan, X. Zhu, X. Li, R. Cao, Eur. J. Inorg. Chem. (2008) pp. 1326-1331.

49. Z. Chen, Y. Zuo, X.-H. Li, H. Wang, B. Zhao, W. Shi, P. Cheng, J. Molec. Struct. 888 (2008) pp. 360-365.

50. Z.-Z. Lin, J.-H. Luo, M.-C. Hong, R.-H. Wang, L. Han, R. Cao, J. Solid State Chem. 177 (2004) pp. 2494-2498.

51. Z. Lin, F. Jiang, L. Chen, D. Yuan, M. Hong, Inorg. Chem. 44 (2005) pp. $73-76$.

52. Z. Lin, L. Chen, F. Jiang, M. Hong, Inorg. Chem. Commun. 8 (2005) pp. 199-201.

53. Z.-Z. Lin, F.-L. Jiang, L. Chen, D.-Q. Yuan, Y.-F. Zhou, M.-C. Hong, Eur. J. Inorg. Chem. (2005) pp. $77-81$.

54. Z. Tian, T. Song, Y. Fan, S. Shi, L. Wang, Inorg. Chim. Acta 360 (2007) 3424-3430. 
55. Z. Lin, L. Chen, C. Yue, C. Yan, F. Jiang, M. Hong, Inorg. Chim. Acta 361 (2008) pp. 2821-2827.

56. J. Sun, L. Weng, Y. Zhou, J. Chen, Z. Chen, Z. Liu, D. Zhou, Angew. Chem. Int. Ed. 41 (2002) pp. 4471-4473.

57. Y.-Q. Tian, C.-X. Cai, X.-J. Yuan, Y.-Z. Li, T.-W. Wang, X.-Z. You, Chem. Lett. 32 (2003) pp. 796797.

58. Y. Liu, V.C. Kravtsov, D.A. Beauchamp, J.F. Eubank, M. Eddaoudi, J. Amer. Chem. Soc. 127 (2005) pp. 7266-7267.

59. J. Zhang, S. Chen, A. Zingiryan, X. Bu, J. Amer. Chem. Soc. 130 (2008) pp. 17246-17247.

60. J. Zhang, S. Chen, X. Bu, Angew. Chem. Int. Ed. 47 (2008) pp. 5434-5437.

61. B. Gómez-Lor, E. Gutiérrez-Puebla, M. Iglesias, M.A. Monge, C. Ruiz-Valero, N. Snejko, Chem. Mater. 17 (2005) pp. 2568-2573.

62. Z.-Z. Lin, F.-L. Jiang, L. Chen, C.-Y. Yue, D.-Q. Yuan, A.-J. Lin, M.-C. Hong, Cryst. Growth Des. 7 (2007) pp. 1712-1715. 

Appendix A.-Alternate Diagram of and Extensive Structural Information for Compound (1) - $\left[\mathrm{GaCl}_{2}(4-\mathrm{Mepy})_{2}\left(\mathrm{O}_{2} \mathrm{CPh}\right)\right] \cdot 4-\mathrm{Mepy}$

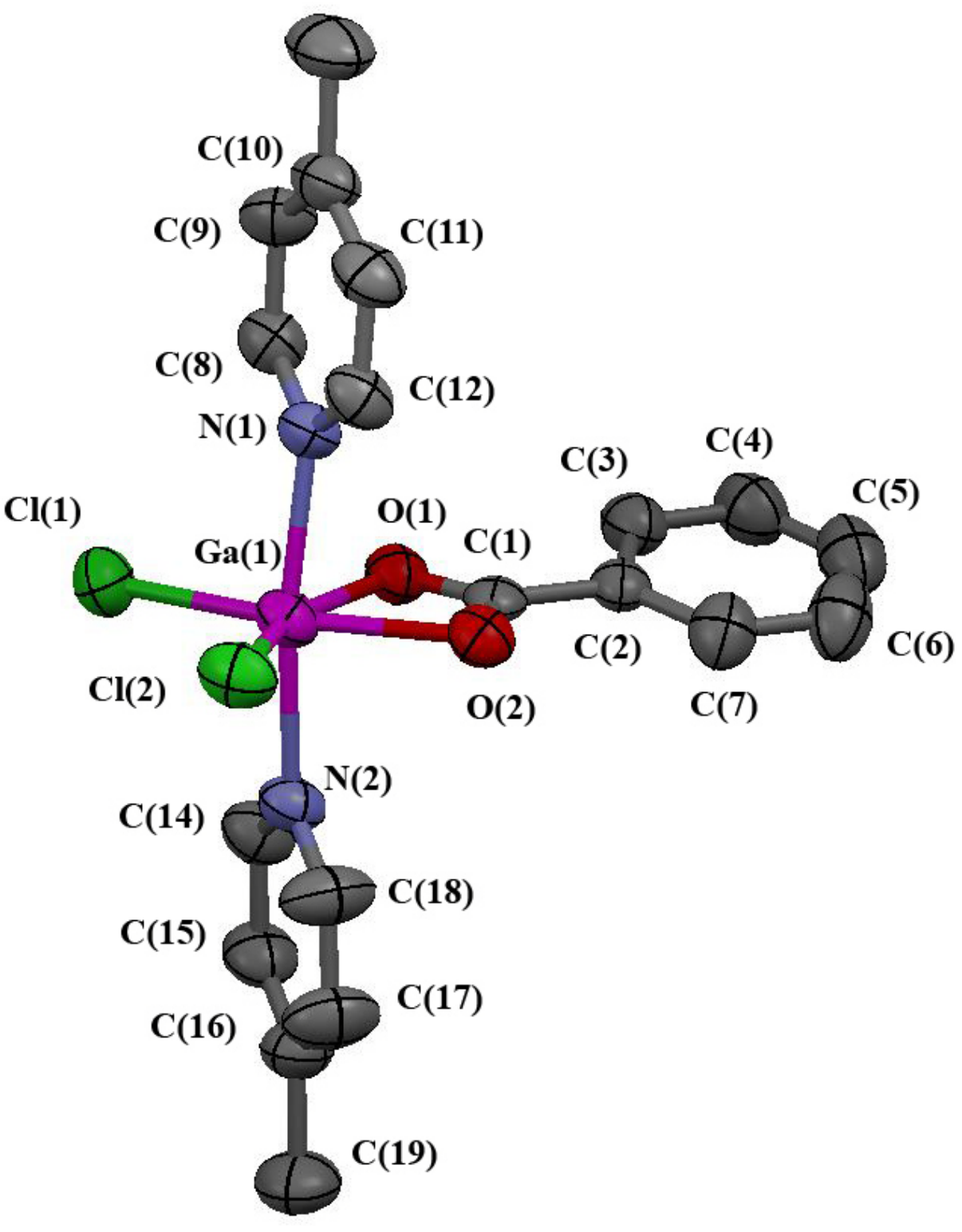


Crystal data

$\mathrm{C}_{25} \mathrm{H}_{26} \mathrm{Cl}_{2} \mathrm{GaN}_{3} \mathrm{O}_{2}$

$M_{r}=541.11$

Triclinic, $P \overline{1}$

$a=10.5987(13) \AA$

$b=11.3705(15) \AA$

$c=12.6660$ (17) $\AA$

$\alpha=104.525(2)^{\mathrm{o}}$

$\beta=101.976(3)^{\circ}$

$\gamma=111.981(2)^{\circ}$

$V=1290.7(3) \AA^{3}$

\section{Data collection}

$\mathrm{CCD}$ area detector diffractometer

Radiation source: fine-focus sealed tube

Monochromator: graphite

$T=300 \mathrm{~K}$

phi and $\omega$ scans

Absorption correction: empirical (using intensity measurements)

SADABS, Absorption corrections using Bruker CCD $h=-12 \rightarrow 7$

based on the method of Bob Blessing. Acta Cryst. 1995, A51, 33

$T_{\min }=0.537, T_{\max }=1.000$

6882 measured reflections

\section{Refinement}

Refinement on $F^{2}$

Least-squares matrix: full

$R\left[F^{2}>2 \sigma\left(F^{2}\right)\right]=0.044$

$w R\left(F^{2}\right)=0.084$

$S=1.00$

4505 reflections

298 parameters

Primary atom site location: structure-invariant direct methods

$k=-13 \rightarrow 13$

$l=-13 \rightarrow 15$ sites
$Z=2$

$F_{000}=556$

$D_{\mathrm{x}}=1.392 \mathrm{Mg} \mathrm{m}^{-3}$

Mo $K \alpha$ radiation, $\lambda=0.71073 \AA$

Cell parameters from 1731 reflections

$\theta=2.2-22.3^{\circ}$

$\mu=1.30 \mathrm{~mm}^{-1}$

$T=300 \mathrm{~K}$

Block, colorless

$0.38 \times 0.23 \times 0.09 \mathrm{~mm}$

4505 independent reflections

2485 reflections with $I>2 \sigma(I)$

$R_{\text {int }}=0.029$

$\theta_{\text {max }}=25.0^{\circ}$

$\theta_{\min }=1.8^{\circ}$

Secondary atom site location: difference Fourier map Hydrogen site location: inferred from neighbouring

$\mathrm{H}$ atoms treated by a mixture of independent and constrained refinement

$w=1 /\left[\sigma^{2}\left(F_{\mathrm{o}}{ }^{2}\right)+(0.0202 P)^{2}\right]$

where $P=\left(F_{\mathrm{o}}{ }^{2}+2 F_{\mathrm{c}}{ }^{2}\right) / 3$

$(\Delta / \sigma)_{\max }<0.001$

$\Delta \rho_{\max }=0.48$ e $\AA^{-3}$

$\Delta \rho_{\min }=-0.41 \mathrm{e} \AA^{-3}$

Extinction correction: none 


\section{Special details}

Geometry. All e.s.d.'s (except the e.s.d. in the dihedral angle between two l.s. planes) are estimated using the full covariance matrix. The cell e.s.d.'s are taken into account individually in the estimation of e.s.d.'s in distances, angles and torsion angles; correlations between e.s.d.'s in cell parameters are only used when they are defined by crystal symmetry. An approximate (isotropic) treatnteof cell e.s.d.'s is used for estimating e.s.d.'s involving l.s. planes.

Refinement. Refinement of $F^{2}$ against ALL reflections. The weighted $R$-factor $w R$ and goodness of fit $S$ are based on, $F^{2}$ onventional $R$-factors $R$ are based on $F$, with $F$ set to zero for negative $F^{2}$. The threshold expression of $F^{2}>\sigma\left(F^{2}\right)$ is used only for calculatikg factors (gt) etc. and is not relevant to the choice of reflections for refinement. $R$-factors based on $F^{2}$ are statistically about twice as large as those based on $F$, and $R$ - factors based on ALL data will be even larger.

Fractional atomic coordinates and isotropic or equivalent isotropic displacement parameters $\left(\AA^{2}\right)$

\begin{tabular}{|c|c|c|c|c|}
\hline & $x$ & $y$ & $z$ & $U_{\text {iso }} * / U_{\text {eq }}$ \\
\hline Gal & $-0.23970(5)$ & $-0.44062(5)$ & $-0.25452(4)$ & $0.05802(17)$ \\
\hline $\mathrm{Cl1}$ & $-0.30851(12)$ & $-0.62951(11)$ & $-0.40717(9)$ & $0.0740(3)$ \\
\hline $\mathrm{Cl} 2$ & $-0.18058(11)$ & $-0.49430(12)$ & $-0.09941(9)$ & $0.0765(4)$ \\
\hline $\mathrm{O} 1$ & $-0.2756(3)$ & -0.3260 & $-0.3534(2)$ & $0.0600(7)$ \\
\hline $\mathrm{O} 2$ & -0.1910 & $-0.2382(3)$ & $-0.1639(2)$ & $0.0622(7)$ \\
\hline N1 & $-0.4524(3)$ & -0.4933 & -0.2561 & $0.0539(8)$ \\
\hline $\mathrm{N} 2$ & $-0.0254(3)$ & $-0.3593(3)$ & $-0.2553(3)$ & $0.0610(9)$ \\
\hline N3 & $0.4579(7)$ & $0.1857(6)$ & $-0.0564(5)$ & $0.141(2)$ \\
\hline $\mathrm{C} 1$ & -0.2320 & $-0.2236(4)$ & -0.2594 (4) & $0.0545(11)$ \\
\hline $\mathrm{C} 2$ & -0.2309 (4) & -0.0946 (4) & $-0.2627(4)$ & $0.0531(10)$ \\
\hline $\mathrm{C} 3$ & -0.2995 (4) & -0.0896 (4) & $-0.3650(4)$ & $0.0700(12)$ \\
\hline $\mathrm{H} 3 \mathrm{~A}$ & -0.3453 & -0.1671 & -0.4320 & $0.084 *$ \\
\hline $\mathrm{C} 4$ & $-0.3006(5)$ & $0.0313(6)$ & $-0.3685(5)$ & $0.0837(15)$ \\
\hline $\mathrm{H} 4 \mathrm{~A}$ & -0.3482 & 0.0345 & -0.4374 & $0.100 *$ \\
\hline $\mathrm{C} 5$ & $-0.2326(6)$ & $0.1433(6)$ & $-0.2721(6)$ & 0.0909 (16) \\
\hline $\mathrm{H} 5 \mathrm{~A}$ & -0.2335 & 0.2239 & -0.2750 & $0.109^{*}$ \\
\hline C6 & $-0.1627(6)$ & $0.1412(5)$ & $-0.1704(5)$ & $0.0909(15)$ \\
\hline H6A & -0.1150 & 0.2199 & -0.1045 & $0.109^{*}$ \\
\hline $\mathrm{C} 7$ & $-0.1630(5)$ & $0.0199(5)$ & $-0.1659(4)$ & $0.0749(13)$ \\
\hline $\mathrm{H} 7 \mathrm{~A}$ & -0.1166 & 0.0172 & -0.0963 & $0.090 *$ \\
\hline $\mathrm{C} 8$ & $-0.5613(5)$ & -0.5552 & $-0.3551(4)$ & $0.0635(12)$ \\
\hline $\mathrm{H} 8 \mathrm{~A}$ & -0.5413 & -0.5699 & -0.4240 & $0.076^{*}$ \\
\hline C9 & $-0.7031(5)$ & -0.5987 (4) & $-0.3602(4)$ & $0.0733(13)$ \\
\hline H9A & -0.7767 & -0.6426 & -0.4316 & $0.088^{*}$ \\
\hline $\mathrm{C} 10$ & $-0.7365(5)$ & $-0.5772(5)$ & $-0.2593(5)$ & 0.0735 (13) \\
\hline $\mathrm{C} 11$ & $-0.6231(6)$ & $-0.5084(5)$ & -0.1579 (4) & $0.0761(14)$ \\
\hline H11A & -0.6399 & -0.4884 & -0.0879 & $0.091 *$ \\
\hline $\mathrm{C} 12$ & $-0.4836(5)$ & -0.4684 & $-0.1588(4)$ & $0.0665(12)$ \\
\hline $\mathrm{H} 12 \mathrm{~A}$ & -0.4080 & -0.4220 & -0.0885 & $0.080^{*}$ \\
\hline $\mathrm{C} 13$ & $-0.8909(5)$ & $-0.6276(5)$ & $-0.2597(5)$ & $0.1088(18)$ \\
\hline
\end{tabular}




\begin{tabular}{|c|c|c|c|c|}
\hline $\mathrm{H} 13 \mathrm{~A}$ & -0.9561 & -0.6736 & -0.3381 & $0.163^{*}$ \\
\hline H13B & -0.9058 & -0.5517 & -0.2223 & $0.163^{*}$ \\
\hline $\mathrm{H} 13 \mathrm{C}$ & -0.9086 & -0.6895 & -0.2189 & $0.163^{*}$ \\
\hline $\mathrm{C} 14$ & $0.0025(5)$ & -0.3683 & $-0.3549(4)$ & $0.0702(13)$ \\
\hline H14A & -0.0741 & -0.4104 & -0.4244 & $0.084 *$ \\
\hline $\mathrm{C} 15$ & $0.1426(5)$ & -0.3163 (4) & $-0.3564(4)$ & 0.0767 (14) \\
\hline $\mathrm{H} 15 \mathrm{~A}$ & 0.1582 & -0.3249 & -0.4270 & $0.092 *$ \\
\hline $\mathrm{C} 16$ & $0.2574(5)$ & $-0.2532(5)$ & $-0.2573(5)$ & $0.0754(14)$ \\
\hline $\mathrm{C} 17$ & $0.2266(5)$ & $-0.2450(5)$ & $-0.1556(4)$ & $0.0980(17)$ \\
\hline H17A & 0.3011 & -0.2038 & -0.0848 & $0.118^{*}$ \\
\hline C18 & $0.0855(5)$ & $-0.2982(5)$ & $-0.1596(4)$ & $0.0925(16)$ \\
\hline $\mathrm{H} 18 \mathrm{~A}$ & 0.0675 & -0.2903 & -0.0900 & $0.111^{*}$ \\
\hline C19 & $0.4104(5)$ & -0.1978 (5) & $-0.2558(4)$ & $0.1003(17)$ \\
\hline H19A & 0.4113 & -0.2131 & -0.3336 & $0.150 *$ \\
\hline H19B & 0.4580 & -0.2429 & -0.2213 & $0.150^{*}$ \\
\hline H19C & 0.4600 & -0.1019 & -0.2115 & $0.150^{*}$ \\
\hline $\mathrm{C} 20$ & $0.4810(7)$ & $0.1905(6)$ & $-0.1547(8)$ & $0.114(2)$ \\
\hline $\mathrm{H} 20 \mathrm{~A}$ & 0.5763 & 0.2367 & -0.1505 & $0.137^{*}$ \\
\hline $\mathrm{C} 21$ & $0.3806(9)$ & $0.1355(6)$ & $-0.2581(6)$ & $0.1060(19)$ \\
\hline $\mathrm{H} 21 \mathrm{~A}$ & 0.4063 & 0.1405 & -0.3233 & $0.127 *$ \\
\hline $\mathrm{C} 22$ & $0.2386(8)$ & $0.0712(6)$ & $-0.2676(6)$ & $0.0974(17)$ \\
\hline $\mathrm{C} 23$ & $0.2116(7)$ & $0.0679(7)$ & $-0.1695(8)$ & $0.125(2)$ \\
\hline $\mathrm{H} 23 \mathrm{~A}$ & 0.1167 & 0.0253 & -0.1716 & $0.150^{*}$ \\
\hline $\mathrm{C} 24$ & $0.3193(10)$ & $0.1250(8)$ & $-0.0688(7)$ & $0.165(3)$ \\
\hline $\mathrm{H} 24 \mathrm{~A}$ & 0.2953 & 0.1219 & -0.0026 & $0.197 *$ \\
\hline $\mathrm{C} 25$ & $0.1231(7)$ & $0.0103(7)$ & $-0.3808(6)$ & $0.175(3)$ \\
\hline $\mathrm{H} 25 \mathrm{~A}$ & 0.0310 & -0.0304 & -0.3712 & $0.263^{*}$ \\
\hline $\mathrm{H} 25 \mathrm{~B}$ & 0.1364 & -0.0581 & -0.4328 & $0.263^{*}$ \\
\hline $\mathrm{H} 25 \mathrm{C}$ & 0.1268 & 0.0797 & -0.4121 & $0.263^{*}$ \\
\hline
\end{tabular}

Atomic displacement parameters $\left(\AA^{2}\right)$

$\begin{array}{lllllll} & U^{11} & U^{22} & U^{33} & U^{12} & U^{13} & U^{23} \\ \mathrm{Ga} 1 & 0.0590(3) & 0.0678(3) & 0.0582(3) & 0.0344(3) & 0.0263(2) & 0.0255(3) \\ \mathrm{C} 11 & 0.0780(9) & 0.0679(8) & 0.0761(8) & 0.0371(7) & 0.0308(6) & 0.0155(7) \\ \mathrm{C} 12 & 0.0733(9) & 0.0976(9) & 0.0767(8) & 0.0449(7) & 0.0270(6) & 0.0488(7) \\ \text { O1 } & 0.059(2) & 0.0633(19) & 0.0668(19) & 0.0302(15) & 0.0304(15) & 0.0254(17) \\ \text { O2 } & 0.065(2) & 0.073(2) & 0.0607(19) & 0.0340(15) & 0.0322(15) & 0.0284(17) \\ \text { N1 } & 0.051(2) & 0.064(2) & 0.053(2) & 0.0303(19) & 0.0190(19) & 0.0224(19) \\ \text { N2 } & 0.053(2) & 0.077(3) & 0.059(2) & 0.034(2) & 0.024(2) & 0.021(2) \\ \text { N3 } & 0.121(5) & 0.151(5) & 0.094(4) & 0.028(4) & 0.022(4) & 0.021(4) \\ \text { C1 } & 0.037(3) & 0.060(3) & 0.069(3) & 0.019(2) & 0.029(2) & 0.023(3) \\ \text { C2 } & 0.046(3) & 0.056(3) & 0.063(3) & 0.022(2) & 0.029(2) & 0.023(3) \\ \text { C3 } & 0.064(3) & 0.070(3) & 0.084(4) & 0.033(3) & 0.031(3) & 0.031(3) \\ \text { C4 } & 0.088(4) & 0.089(4) & 0.098(4) & 0.050(3) & 0.038(3) & 0.048(4) \\ \text { C5 } & 0.110(5) & 0.083(4) & 0.118(5) & 0.055(4) & 0.071(4) & 0.052(4) \\ \text { C6 } & 0.121(5) & 0.068(4) & 0.090(4) & 0.038(3) & 0.062(4) & 0.023(3) \\ \text { C7 } & 0.092(4) & 0.070(3) & 0.068(3) & 0.033(3) & 0.041(3) & 0.027(3)\end{array}$




$\begin{array}{lllllll}\text { C8 } & 0.069(3) & 0.075(3) & 0.059(3) & 0.037(3) & 0.028(3) & 0.030(3) \\ \text { C9 } & 0.057(3) & 0.090(4) & 0.074(3) & 0.034(3) & 0.015(3) & 0.034(3) \\ \text { C10 } & 0.059(4) & 0.079(3) & 0.103(4) & 0.038(3) & 0.034(3) & 0.047(3) \\ \text { C11 } & 0.077(4) & 0.095(4) & 0.085(4) & 0.050(3) & 0.047(3) & 0.044(3) \\ \text { C12 } & 0.071(4) & 0.086(3) & 0.055(3) & 0.046(3) & 0.027(3) & 0.026(3) \\ \text { C13 } & 0.071(4) & 0.120(4) & 0.162(5) & 0.047(3) & 0.060(4) & 0.069(4) \\ \text { C14 } & 0.069(4) & 0.091(3) & 0.061(3) & 0.043(3) & 0.027(3) & 0.029(3) \\ \text { C15 } & 0.073(4) & 0.090(4) & 0.082(4) & 0.039(3) & 0.047(3) & 0.036(3) \\ \text { C16 } & 0.054(3) & 0.083(4) & 0.083(4) & 0.028(3) & 0.027(3) & 0.021(3) \\ \text { C17 } & 0.062(4) & 0.135(5) & 0.066(4) & 0.026(3) & 0.012(3) & 0.025(3) \\ \text { C18 } & 0.053(4) & 0.131(5) & 0.058(3) & 0.019(3) & 0.017(3) & 0.015(3) \\ \text { C19 } & 0.066(4) & 0.107(4) & 0.125(5) & 0.030(3) & 0.046(3) & 0.040(4) \\ \text { C20 } & 0.076(5) & 0.110(5) & 0.134(6) & 0.029(4) & 0.043(5) & 0.023(5) \\ \text { C21 } & 0.098(6) & 0.112(5) & 0.125(6) & 0.046(4) & 0.061(5) & 0.053(5) \\ \text { C22 } & 0.106(6) & 0.088(4) & 0.103(5) & 0.049(4) & 0.027(5) & 0.039(4) \\ \text { C23 } & 0.083(5) & 0.141(6) & 0.134(6) & 0.032(4) & 0.050(5) & 0.042(5) \\ \text { C24 } & 0.112(7) & 0.192(8) & 0.116(7) & 0.010(6) & 0.056(6) & 0.016(6) \\ \text { C25 } & 0.156(7) & 0.187(7) & 0.147(6) & 0.068(5) & -0.009(5) & 0.068(6)\end{array}$

Geometric parameters $\left(A,{ }^{\circ}\right)$

\begin{tabular}{|c|c|c|c|}
\hline $\mathrm{Ga} 1-\mathrm{O} 1$ & $2.099(2)$ & $\mathrm{C} 4-\mathrm{C} 5$ & $1.342(6)$ \\
\hline $\mathrm{Ga} 1-\mathrm{N} 1$ & $2.099(3)$ & $\mathrm{C} 5-\mathrm{C} 6$ & $1.357(6)$ \\
\hline $\mathrm{Ga} 1-\mathrm{O} 2$ & $2.102(3)$ & $\mathrm{C} 6-\mathrm{C} 7$ & $1.394(6)$ \\
\hline $\mathrm{Ga} 1-\mathrm{N} 2$ & $2.111(3)$ & $\mathrm{C} 8-\mathrm{C} 9$ & $1.377(5)$ \\
\hline $\mathrm{Ga} 1-\mathrm{Cl} 2$ & $2.2365(11)$ & $\mathrm{C} 9-\mathrm{C} 10$ & $1.383(6)$ \\
\hline $\mathrm{Ga} 1-\mathrm{Cl1}$ & $2.2455(11)$ & $\mathrm{C} 10-\mathrm{C} 11$ & $1.364(6)$ \\
\hline $\mathrm{Ga} 1-\mathrm{C} 1$ & $2.455(4)$ & $\mathrm{C} 10-\mathrm{C} 13$ & $1.516(5)$ \\
\hline $\mathrm{O} 1-\mathrm{C} 1$ & $1.288(4)$ & $\mathrm{C} 11-\mathrm{C} 12$ & $1.378(5)$ \\
\hline $\mathrm{O} 2-\mathrm{C} 1$ & $1.271(4)$ & $\mathrm{C} 14-\mathrm{C} 15$ & $1.384(5)$ \\
\hline $\mathrm{N} 1-\mathrm{C} 8$ & $1.322(4)$ & $\mathrm{C} 15-\mathrm{C} 16$ & $1.354(5)$ \\
\hline $\mathrm{N} 1-\mathrm{C} 12$ & $1.331(4)$ & $\mathrm{C} 16-\mathrm{C} 17$ & $1.383(6)$ \\
\hline $\mathrm{N} 2-\mathrm{C} 18$ & $1.307(5)$ & $\mathrm{C} 16-\mathrm{C} 19$ & $1.498(5)$ \\
\hline $\mathrm{N} 2-\mathrm{C} 14$ & $1.342(5)$ & $\mathrm{C} 17-\mathrm{C} 18$ & $1.372(6)$ \\
\hline N3-C24 & $1.323(7)$ & $\mathrm{C} 20-\mathrm{C} 21$ & $1.323(7)$ \\
\hline $\mathrm{N} 3-\mathrm{C} 20$ & $1.329(7)$ & $\mathrm{C} 21-\mathrm{C} 22$ & $1.368(7)$ \\
\hline $\mathrm{C} 1-\mathrm{C} 2$ & $1.474(5)$ & $\mathrm{C} 22-\mathrm{C} 23$ & $1.338(7)$ \\
\hline $\mathrm{C} 2-\mathrm{C} 7$ & $1.359(5)$ & $\mathrm{C} 22-\mathrm{C} 25$ & $1.474(7)$ \\
\hline $\mathrm{C} 2-\mathrm{C} 3$ & $1.374(5)$ & $\mathrm{C} 23-\mathrm{C} 24$ & $1.333(8)$ \\
\hline $\mathrm{C} 3-\mathrm{C} 4$ & $1.391(5)$ & & \\
\hline $\mathrm{O} 1-\mathrm{Ga} 1-\mathrm{N} 1$ & $85.47(10)$ & $\mathrm{O} 2-\mathrm{C} 1-\mathrm{Ga} 1$ & $58.9(2)$ \\
\hline $\mathrm{O} 1-\mathrm{Ga} 1-\mathrm{O} 2$ & $62.83(10)$ & $\mathrm{O} 1-\mathrm{C} 1-\mathrm{Ga} 1$ & $58.7(2)$ \\
\hline $\mathrm{N} 1-\mathrm{Ga} 1-\mathrm{O} 2$ & $87.21(11)$ & $\mathrm{C} 2-\mathrm{C} 1-\mathrm{Ga} 1$ & $178.7(2)$ \\
\hline $\mathrm{O} 1-\mathrm{Ga} 1-\mathrm{N} 2$ & $86.64(11)$ & $\mathrm{C} 7-\mathrm{C} 2-\mathrm{C} 3$ & $119.3(4)$ \\
\hline $\mathrm{N} 1-\mathrm{Ga} 1-\mathrm{N} 2$ & $171.04(12)$ & $\mathrm{C} 7-\mathrm{C} 2-\mathrm{C} 1$ & $121.0(4)$ \\
\hline $\mathrm{O} 2-\mathrm{Ga} 1-\mathrm{N} 2$ & $85.43(11)$ & $\mathrm{C} 3-\mathrm{C} 2-\mathrm{C} 1$ & $119.7(4)$ \\
\hline $\mathrm{O} 1-\mathrm{Ga} 1-\mathrm{Cl} 2$ & $159.73(8)$ & $\mathrm{C} 2-\mathrm{C} 3-\mathrm{C} 4$ & $120.0(4)$ \\
\hline $\mathrm{N} 1-\mathrm{Ga} 1-\mathrm{Cl} 2$ & $93.01(9)$ & $\mathrm{C} 5-\mathrm{C} 4-\mathrm{C} 3$ & $119.7(5)$ \\
\hline $\mathrm{O} 2-\mathrm{Ga} 1-\mathrm{Cl} 2$ & $96.92(8)$ & $\mathrm{C} 4-\mathrm{C} 5-\mathrm{C} 6$ & $121.3(5)$ \\
\hline
\end{tabular}




\begin{tabular}{|c|c|c|c|}
\hline $\mathrm{N} 2-\mathrm{Ga} 1-\mathrm{Cl} 2$ & $92.92(10)$ & $\mathrm{C} 5-\mathrm{C} 6-\mathrm{C} 7$ & $119.3(5)$ \\
\hline $\mathrm{O} 1-\mathrm{Ga} 1-\mathrm{Cl} 1$ & $95.30(8)$ & $\mathrm{C} 2-\mathrm{C} 7-\mathrm{C} 6$ & $120.4(5)$ \\
\hline $\mathrm{N} 1-\mathrm{Ga} 1-\mathrm{Cl} 1$ & $92.62(10)$ & $\mathrm{N} 1-\mathrm{C} 8-\mathrm{C} 9$ & $122.6(4)$ \\
\hline $\mathrm{O} 2-\mathrm{Ga} 1-\mathrm{Cl} 1$ & $158.09(8)$ & $\mathrm{C} 8-\mathrm{C} 9-\mathrm{C} 10$ & $120.2(4)$ \\
\hline $\mathrm{N} 2-\mathrm{Ga} 1-\mathrm{C} 11$ & $92.32(10)$ & $\mathrm{C} 11-\mathrm{C} 10-\mathrm{C} 9$ & $116.7(4)$ \\
\hline $\mathrm{Cl} 2-\mathrm{Ga} 1-\mathrm{Cl} 1$ & $104.96(4)$ & $\mathrm{C} 11-\mathrm{C} 10-\mathrm{C} 13$ & $120.9(5)$ \\
\hline $\mathrm{O} 1-\mathrm{Ga} 1-\mathrm{C} 1$ & $31.65(11)$ & $\mathrm{C} 9-\mathrm{C} 10-\mathrm{C} 13$ & $122.4(5)$ \\
\hline $\mathrm{N} 1-\mathrm{Ga} 1-\mathrm{C} 1$ & $85.39(11)$ & $\mathrm{C} 10-\mathrm{C} 11-\mathrm{C} 12$ & $120.2(5)$ \\
\hline $\mathrm{O} 2-\mathrm{Ga} 1-\mathrm{C} 1$ & $31.18(11)$ & $\mathrm{N} 1-\mathrm{C} 12-\mathrm{C} 11$ & $122.8(4)$ \\
\hline $\mathrm{N} 2-\mathrm{Ga} 1-\mathrm{C} 1$ & $85.67(12)$ & $\mathrm{N} 2-\mathrm{C} 14-\mathrm{C} 15$ & $121.5(4)$ \\
\hline $\mathrm{Cl} 2-\mathrm{Ga} 1-\mathrm{C} 1$ & $128.08(11)$ & $\mathrm{C} 16-\mathrm{C} 15-\mathrm{C} 14$ & $121.3(5)$ \\
\hline $\mathrm{C} 11-\mathrm{Ga} 1-\mathrm{C} 1$ & $126.95(11)$ & $\mathrm{C} 15-\mathrm{C} 16-\mathrm{C} 17$ & $116.4(5)$ \\
\hline $\mathrm{C} 1-\mathrm{O} 1-\mathrm{Ga} 1$ & $89.6(2)$ & $\mathrm{C} 15-\mathrm{C} 16-\mathrm{C} 19$ & $122.7(5)$ \\
\hline $\mathrm{C} 1-\mathrm{O} 2-\mathrm{Ga} 1$ & $89.9(2)$ & $\mathrm{C} 17-\mathrm{C} 16-\mathrm{C} 19$ & $120.9(5)$ \\
\hline $\mathrm{C} 8-\mathrm{N} 1-\mathrm{C} 12$ & $117.5(4)$ & $\mathrm{C} 18-\mathrm{C} 17-\mathrm{C} 16$ & $119.6(4)$ \\
\hline $\mathrm{C} 8-\mathrm{N} 1-\mathrm{Ga} 1$ & $120.6(3)$ & $\mathrm{N} 2-\mathrm{C} 18-\mathrm{C} 17$ & $124.0(5)$ \\
\hline $\mathrm{C} 12-\mathrm{N} 1-\mathrm{Ga} 1$ & $121.9(3)$ & $\mathrm{C} 21-\mathrm{C} 20-\mathrm{N} 3$ & $125.9(6)$ \\
\hline $\mathrm{C} 18-\mathrm{N} 2-\mathrm{C} 14$ & $117.2(4)$ & $\mathrm{C} 20-\mathrm{C} 21-\mathrm{C} 22$ & $119.1(7)$ \\
\hline $\mathrm{C} 18-\mathrm{N} 2-\mathrm{Ga} 1$ & $121.8(3)$ & $\mathrm{C} 23-\mathrm{C} 22-\mathrm{C} 21$ & $116.5(6)$ \\
\hline $\mathrm{C} 14-\mathrm{N} 2-\mathrm{Ga} 1$ & $121.1(3)$ & $\mathrm{C} 23-\mathrm{C} 22-\mathrm{C} 25$ & $122.6(8)$ \\
\hline $\mathrm{C} 24-\mathrm{N} 3-\mathrm{C} 20$ & $113.2(6)$ & $\mathrm{C} 21-\mathrm{C} 22-\mathrm{C} 25$ & $120.9(8)$ \\
\hline $\mathrm{O} 2-\mathrm{C} 1-\mathrm{O} 1$ & $117.6(4)$ & $\mathrm{C} 24-\mathrm{C} 23-\mathrm{C} 22$ & $120.7(7)$ \\
\hline $\mathrm{O} 2-\mathrm{C} 1-\mathrm{C} 2$ & $121.3(4)$ & $\mathrm{N} 3-\mathrm{C} 24-\mathrm{C} 23$ & $124.6(7)$ \\
\hline $\mathrm{O} 1-\mathrm{C} 1-\mathrm{C} 2$ & $121.0(4)$ & & \\
\hline $\mathrm{N} 1-\mathrm{Ga} 1-\mathrm{O} 1-\mathrm{C} 1$ & $88.6(2)$ & $\mathrm{O} 1-\mathrm{Ga} 1-\mathrm{C} 1-\mathrm{C} 2$ & $81(15)$ \\
\hline $\mathrm{O} 2-\mathrm{Ga} 1-\mathrm{O} 1-\mathrm{C} 1$ & $-0.62(19)$ & $\mathrm{N} 1-\mathrm{Ga} 1-\mathrm{C} 1-\mathrm{C} 2$ & $-8(15)$ \\
\hline $\mathrm{N} 2-\mathrm{Ga} 1-\mathrm{O} 1-\mathrm{C} 1$ & $-87.2(2)$ & $\mathrm{O} 2-\mathrm{Ga} 1-\mathrm{C} 1-\mathrm{C} 2$ & $-100(15)$ \\
\hline $\mathrm{Cl} 2-\mathrm{Ga} 1-\mathrm{O} 1-\mathrm{C} 1$ & $2.1(3)$ & $\mathrm{N} 2-\mathrm{Ga} 1-\mathrm{C} 1-\mathrm{C} 2$ & $171(15)$ \\
\hline $\mathrm{C} 11-\mathrm{Ga} 1-\mathrm{O} 1-\mathrm{C} 1$ & $-179.22(18)$ & $\mathrm{C} 12-\mathrm{Ga} 1-\mathrm{C} 1-\mathrm{C} 2$ & $-98(15)$ \\
\hline $\mathrm{O} 1-\mathrm{Ga} 1-\mathrm{O} 2-\mathrm{C} 1$ & $0.63(19)$ & $\mathrm{C} 11-\mathrm{Ga} 1-\mathrm{C} 1-\mathrm{C} 2$ & $82(15)$ \\
\hline $\mathrm{N} 1-\mathrm{Ga} 1-\mathrm{O} 2-\mathrm{C} 1$ & $-85.7(2)$ & $\mathrm{O} 2-\mathrm{C} 1-\mathrm{C} 2-\mathrm{C} 7$ & $11.6(5)$ \\
\hline $\mathrm{N} 2-\mathrm{Ga} 1-\mathrm{O} 2-\mathrm{C} 1$ & $89.2(2)$ & $\mathrm{O} 1-\mathrm{C} 1-\mathrm{C} 2-\mathrm{C} 7$ & $-168.9(3)$ \\
\hline $\mathrm{Cl} 2-\mathrm{Ga} 1-\mathrm{O} 2-\mathrm{C} 1$ & $-178.42(19)$ & $\mathrm{Ga} 1-\mathrm{C} 1-\mathrm{C} 2-\mathrm{C} 7$ & $111(15)$ \\
\hline $\mathrm{C} 11-\mathrm{Ga} 1-\mathrm{O} 2-\mathrm{C} 1$ & $4.4(3)$ & $\mathrm{O} 2-\mathrm{C} 1-\mathrm{C} 2-\mathrm{C} 3$ & $-168.3(4)$ \\
\hline $\mathrm{O} 1-\mathrm{Ga} 1-\mathrm{N} 1-\mathrm{C} 8$ & $58.8(3)$ & $\mathrm{O} 1-\mathrm{C} 1-\mathrm{C} 2-\mathrm{C} 3$ & $11.2(5)$ \\
\hline $\mathrm{O} 2-\mathrm{Ga} 1-\mathrm{N} 1-\mathrm{C} 8$ & $121.7(3)$ & $\mathrm{Ga} 1-\mathrm{C} 1-\mathrm{C} 2-\mathrm{C} 3$ & $-69(15)$ \\
\hline $\mathrm{N} 2-\mathrm{Ga} 1-\mathrm{N} 1-\mathrm{C} 8$ & $87.1(10)$ & $\mathrm{C} 7-\mathrm{C} 2-\mathrm{C} 3-\mathrm{C} 4$ & $-0.8(6)$ \\
\hline $\mathrm{Cl} 2-\mathrm{Ga} 1-\mathrm{N} 1-\mathrm{C} 8$ & $-141.5(3)$ & $\mathrm{C} 1-\mathrm{C} 2-\mathrm{C} 3-\mathrm{C} 4$ & $179.2(3)$ \\
\hline $\mathrm{C} 11-\mathrm{Ga} 1-\mathrm{N} 1-\mathrm{C} 8$ & $-36.3(3)$ & $\mathrm{C} 2-\mathrm{C} 3-\mathrm{C} 4-\mathrm{C} 5$ & $1.0(7)$ \\
\hline $\mathrm{C} 1-\mathrm{Ga} 1-\mathrm{N} 1-\mathrm{C} 8$ & $90.6(3)$ & $\mathrm{C} 3-\mathrm{C} 4-\mathrm{C} 5-\mathrm{C} 6$ & $-0.2(7)$ \\
\hline $\mathrm{O} 1-\mathrm{Ga} 1-\mathrm{N} 1-\mathrm{C} 12$ & $-122.4(3)$ & $\mathrm{C} 4-\mathrm{C} 5-\mathrm{C} 6-\mathrm{C} 7$ & $-0.8(8)$ \\
\hline $\mathrm{O} 2-\mathrm{Ga} 1-\mathrm{N} 1-\mathrm{C} 12$ & $-59.4(3)$ & $\mathrm{C} 3-\mathrm{C} 2-\mathrm{C} 7-\mathrm{C} 6$ & $-0.2(6)$ \\
\hline $\mathrm{N} 2-\mathrm{Ga} 1-\mathrm{N} 1-\mathrm{C} 12$ & $-94.1(9)$ & $\mathrm{C} 1-\mathrm{C} 2-\mathrm{C} 7-\mathrm{C} 6$ & $179.9(4)$ \\
\hline $\mathrm{Cl} 2-\mathrm{Ga} 1-\mathrm{N} 1-\mathrm{C} 12$ & $37.4(3)$ & $\mathrm{C} 5-\mathrm{C} 6-\mathrm{C} 7-\mathrm{C} 2$ & $1.0(7)$ \\
\hline $\mathrm{C} 11-\mathrm{Ga} 1-\mathrm{N} 1-\mathrm{C} 12$ & $142.5(3)$ & $\mathrm{C} 12-\mathrm{N} 1-\mathrm{C} 8-\mathrm{C} 9$ & $-2.8(6)$ \\
\hline $\mathrm{C} 1-\mathrm{Ga} 1-\mathrm{N} 1-\mathrm{C} 12$ & $-90.6(3)$ & $\mathrm{Ga} 1-\mathrm{N} 1-\mathrm{C} 8-\mathrm{C} 9$ & $176.1(3)$ \\
\hline $\mathrm{O} 1-\mathrm{Ga} 1-\mathrm{N} 2-\mathrm{C} 18$ & $126.9(4)$ & $\mathrm{N} 1-\mathrm{C} 8-\mathrm{C} 9-\mathrm{C} 10$ & $0.6(6)$ \\
\hline $\mathrm{N} 1-\mathrm{Ga} 1-\mathrm{N} 2-\mathrm{C} 18$ & $98.6(9)$ & $\mathrm{C} 8-\mathrm{C} 9-\mathrm{C} 10-\mathrm{C} 11$ & $2.0(6)$ \\
\hline $\mathrm{O} 2-\mathrm{Ga} 1-\mathrm{N} 2-\mathrm{C} 18$ & $63.9(4)$ & $\mathrm{C} 8-\mathrm{C} 9-\mathrm{C} 10-\mathrm{C} 13$ & $-177.6(4)$ \\
\hline
\end{tabular}




$\begin{array}{ll}\mathrm{C} 12-\mathrm{Ga} 1-\mathrm{N} 2-\mathrm{C} 18 & -32.8(4) \\ \mathrm{C} 11-\mathrm{Ga} 1-\mathrm{N} 2-\mathrm{C} 18 & -138.0(3) \\ \mathrm{C} 1-\mathrm{Ga} 1-\mathrm{N} 2-\mathrm{C} 18 & 95.2(4) \\ \mathrm{O} 1-\mathrm{Ga} 1-\mathrm{N} 2-\mathrm{C} 14 & -53.1(3) \\ \mathrm{N} 1-\mathrm{Ga} 1-\mathrm{N} 2-\mathrm{C} 14 & -81.3(10) \\ \mathrm{O} 2-\mathrm{Ga} 1-\mathrm{N} 2-\mathrm{C} 14 & -116.1(3) \\ \mathrm{C} 12-\mathrm{Ga} 1-\mathrm{N} 2-\mathrm{C} 14 & 147.2(3) \\ \mathrm{C} 11-\mathrm{Ga} 1-\mathrm{N} 2-\mathrm{C} 14 & 42.1(3) \\ \mathrm{C} 1-\mathrm{Ga} 1-\mathrm{N} 2-\mathrm{C} 14 & -84.8(3) \\ \mathrm{Ga} 1-\mathrm{O} 2-\mathrm{C} 1-\mathrm{O} 1 & -1.0(3) \\ \mathrm{Ga} 1-\mathrm{O} 2-\mathrm{C} 1-\mathrm{C} 2 & 178.5(3) \\ \mathrm{Ga} 1-\mathrm{O} 1-\mathrm{C} 1-\mathrm{O} 2 & 1.0(3) \\ \mathrm{Ga} 1-\mathrm{O} 1-\mathrm{C} 1-\mathrm{C} 2 & -178.5(3) \\ \mathrm{O} 1-\mathrm{Ga} 1-\mathrm{C} 1-\mathrm{O} 2 & -178.9(3) \\ \mathrm{N} 1-\mathrm{Ga} 1-\mathrm{C} 1-\mathrm{O} 2 & 92.2(2) \\ \mathrm{N} 2-\mathrm{Ga} 1-\mathrm{C} 1-\mathrm{O} 2 & -88.3(2) \\ \mathrm{C} 12-\mathrm{Ga} 1-\mathrm{C} 1-\mathrm{O} 2 & 2.0(2) \\ \mathrm{C} 11-\mathrm{Ga} 1-\mathrm{C} 1-\mathrm{O} 2 & -177.97(16) \\ \mathrm{N} 1-\mathrm{Ga} 1-\mathrm{C} 1-\mathrm{O} 1 & -88.8(2) \\ \mathrm{O} 2-\mathrm{Ga} 1-\mathrm{C} 1-\mathrm{O} 1 & 178.9(3) \\ \mathrm{N} 2-\mathrm{Ga} 1-\mathrm{C} 1-\mathrm{O} 1 & 90.6(2) \\ \mathrm{C} 12-\mathrm{Ga} 1-\mathrm{C} 1-\mathrm{O} 1 & -179.06(15) \\ \mathrm{C} 11-\mathrm{Ga} 1-\mathrm{C} 1-\mathrm{O} 1 & 1.0(2) \\ & \end{array}$

$\begin{array}{ll}\mathrm{C} 9-\mathrm{C} 10-\mathrm{C} 11-\mathrm{C} 12 & -2.4(6) \\ \mathrm{C} 13-\mathrm{C} 10-\mathrm{C} 11-\mathrm{C} 12 & 177.2(4) \\ \mathrm{C} 8-\mathrm{N} 1-\mathrm{C} 12-\mathrm{C} 11 & 2.3(6) \\ \mathrm{G} 1-\mathrm{N} 1-\mathrm{C} 12-\mathrm{C} 11 & -176.6(3) \\ \mathrm{C} 10-\mathrm{C} 11-\mathrm{C} 12-\mathrm{N} 1 & 0.4(6) \\ \mathrm{C} 18-\mathrm{N} 2-\mathrm{C} 14-\mathrm{C} 15 & 0.6(6) \\ \mathrm{G} 1-\mathrm{N} 2-\mathrm{C} 14-\mathrm{C} 15 & -179.5(3) \\ \mathrm{N} 2-\mathrm{C} 14-\mathrm{C} 15-\mathrm{C} 16 & -0.5(7) \\ \mathrm{C} 14-\mathrm{C} 15-\mathrm{C} 16-\mathrm{C} 17 & 0.6(7) \\ \mathrm{C} 14-\mathrm{C} 15-\mathrm{C} 16-\mathrm{C} 19 & 178.9(4) \\ \mathrm{C} 15-\mathrm{C} 16-\mathrm{C} 17-\mathrm{C} 18 & -0.8(7) \\ \mathrm{C} 19-\mathrm{C} 16-\mathrm{C} 17-\mathrm{C} 18 & -179.1(4) \\ \mathrm{C} 14-\mathrm{N} 2-\mathrm{C} 18-\mathrm{C} 17 & -0.8(7) \\ \mathrm{G} 1-\mathrm{N} 2-\mathrm{C} 18-\mathrm{C} 17 & 179.3(4) \\ \mathrm{C} 16-\mathrm{C} 17-\mathrm{C} 18-\mathrm{N} 2 & 0.9(8) \\ \mathrm{C} 24-\mathrm{N} 3-\mathrm{C} 20-\mathrm{C} 21 & -3.6(11) \\ \mathrm{N} 3-\mathrm{C} 20-\mathrm{C} 21-\mathrm{C} 22 & 2.6(10) \\ \mathrm{C} 20-\mathrm{C} 21-\mathrm{C} 22-\mathrm{C} 23 & -0.6(9) \\ \mathrm{C} 20-\mathrm{C} 21-\mathrm{C} 22-\mathrm{C} 25 & 179.1(5) \\ \mathrm{C} 21-\mathrm{C} 22-\mathrm{C} 23-\mathrm{C} 24 & 0.0(10) \\ \mathrm{C} 25-\mathrm{C} 22-\mathrm{C} 23-\mathrm{C} 24 & -179.6(7) \\ \mathrm{C} 20-\mathrm{N} 3-\mathrm{C} 24-\mathrm{C} 23 & 3.0(12) \\ \mathrm{C} 22-\mathrm{C} 23-\mathrm{C} 24-\mathrm{N} 3 & -1.4(13)\end{array}$



Appendix B.- Alternate Diagram of and Extensive Structural Information for Compound (2) - [ InCl(4-Mepy $\left.)_{2}\left(\mathrm{O}_{2} \mathrm{CPh}\right)_{2}\right] \bullet 4-\mathrm{Mepy}$

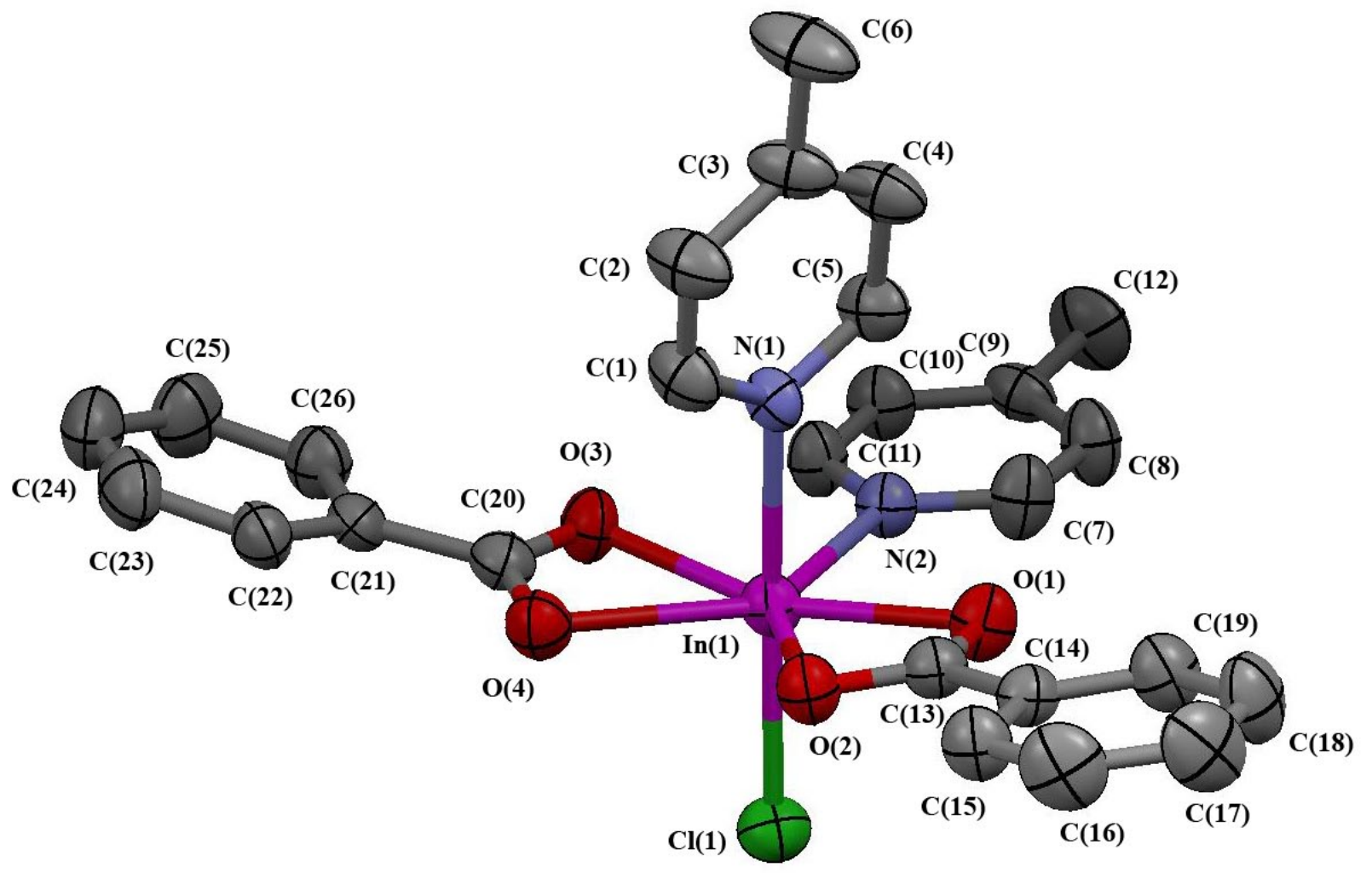


Crystal data

$\mathrm{C}_{32} \mathrm{H}_{31} \mathrm{ClInN}_{3} \mathrm{O}_{4}$

$F_{000}=1368$

$M_{r}=671.87$

Monoclinic, $P 2(1) / n$

$D_{\mathrm{x}}=1.439 \mathrm{Mg} \mathrm{m}^{-3}$

$a=13.1565$ (13) $\AA$

Mo $K \alpha$ radiation, $\lambda=0.71073 \AA$

$b=8.2116(8) \AA$

Cell parameters from 3347 reflections

$c=28.796(3) \AA$

$\theta=2.5-22.2^{\circ}$

$\mu=0.89 \mathrm{~mm}^{-1}$

$\beta=94.460(2)^{\mathrm{o}}$

$T=300 \mathrm{~K}$

$V=3101.6(5) \AA^{3}$

Block, colorless

$Z=4$

$0.31 \times 0.14 \times 0.08 \mathrm{~mm}$

\section{Data collection}

CCD area detector

diffractometer

5462 independent reflections

Radiation source: fine-focus sealed tube

3611 reflections with $I>2 \sigma(I)$

Monochromator: graphite

$R_{\text {int }}=0.054$

$T=300 \mathrm{~K}$

$\theta_{\max }=25.0^{\circ}$

phi and $\omega$ scans

$\theta_{\min }=1.7^{\circ}$

Absorption correction: empirical (using intensity measurements)

SADABS, Absorption corrections using Bruker CCD $h=-15 \rightarrow 8$

based on the method of Bob Blessing. Acta Cryst. 1995, A51, 33

$T_{\min }=0.580, T_{\max }=1.000$

$k=-9 \rightarrow 9$

15267 measured reflections

$l=-34 \rightarrow 34$

\section{Refinement}

Refinement on $F^{2}$

Least-squares matrix: full

$R\left[F^{2}>2 \sigma\left(F^{2}\right)\right]=0.053$

$w R\left(F^{2}\right)=0.119$

$S=1.00$

5462 reflections

370 parameters
Secondary atom site location: difference Fourier map Hydrogen site location: inferred from neighbouring sites

$\mathrm{H}$ atoms treated by a mixture of independent and constrained refinement

$w=1 /\left[\sigma^{2}\left(F_{\mathrm{o}}^{2}\right)+(0.0584 P)^{2}\right]$

where $P=\left(F_{\mathrm{o}}{ }^{2}+2 F_{\mathrm{c}}{ }^{2}\right) / 3$

$(\Delta / \sigma)_{\max }=0.001$

$\Delta \rho_{\max }=1.17$ e $\AA^{-3}$

$\Delta \rho_{\min }=-0.47$ e $\AA^{-3}$

Primary atom site location: structure-invariant direct methods

Extinction correction: none 


\section{Special details}

Geometry. All e.s.d.'s (except the e.s.d. in the dihedral angle between two 1.s. planes) are estimated using the full covariance matrix. The cell e.s.d.'s are taken into account individually in the estimation of e.s.d.'s in distances, angles and torsion anglecorrelations between e.s.d.'s in cell parameters are only used when they are defined by crystal symmetry. An approximate (isotropic) treatmmeof cell e.s.d.'s is used for estimating e.s.d.'s involving l.s. planes.

Refinement. Refinement of $F^{2}$ against ALL reflections. The weighted $R$-factor $w R$ and goodness of fit $S$ are based $\delta^{2}$, conventional $R$-factors $R$ are based on $F$, with $F$ set to zero for negative $F^{2}$. The threshold expression of $F^{2}>\sigma\left(F^{2}\right)$ is used only for calculating factors $(\mathrm{gt})$ etc. and is not relevant to the choice of reflections for refinement. $R$-factors based on $F^{2}$ are statistically about twice as large as those based on $F$, and $R$ - factors based on ALL data will be even larger.

Fractional atomic coordinates and isotropic or equivalent isotropic displacement parameters $\left(\AA^{2}\right)$

\begin{tabular}{|c|c|c|c|c|}
\hline & $x$ & $y$ & $z$ & $U_{\text {iso }} * / U_{\text {eq }}$ \\
\hline In1 & $0.68251(3)$ & $1.41205(5)$ & $0.578113(12)$ & $0.04688(15)$ \\
\hline $\mathrm{Cl} 2$ & $0.58777(11)$ & $1.65800(18)$ & $0.59029(5)$ & $0.0592(4)$ \\
\hline $\mathrm{O} 1$ & $0.6919(3)$ & $1.3314(5)$ & $0.65388(11)$ & $0.0561(10)$ \\
\hline $\mathrm{O} 2$ & $0.8143(3)$ & $1.4832(5)$ & $0.63096(12)$ & $0.0553(10)$ \\
\hline $\mathrm{O} 3$ & $0.6614(3)$ & $1.4110(5)$ & $0.50116(12)$ & $0.0588(10)$ \\
\hline $\mathrm{O} 4$ & $0.7972(3)$ & $1.5404(5)$ & $0.52763(13)$ & $0.0602(10)$ \\
\hline N1 & $0.7836(3)$ & $1.1841(5)$ & $0.57169(13)$ & $0.0432(10)$ \\
\hline $\mathrm{N} 2$ & $0.5396(3)$ & $1.2527(5)$ & $0.57165(14)$ & $0.0460(10)$ \\
\hline $\mathrm{N} 3$ & $0.2568(6)$ & $0.9454(9)$ & $0.6921(3)$ & $0.104(2)$ \\
\hline $\mathrm{C} 1$ & $0.8773(5)$ & $1.1979(7)$ & $0.5588(2)$ & $0.0637(16)$ \\
\hline $\mathrm{H} 1 \mathrm{~A}$ & 0.8982 & 1.2993 & 0.5488 & $0.076^{*}$ \\
\hline $\mathrm{C} 2$ & $0.9459(5)$ & $1.0715(8)$ & $0.5593(2)$ & $0.0733(18)$ \\
\hline $\mathrm{H} 2 \mathrm{~A}$ & 1.0108 & 1.0881 & 0.5495 & $0.088^{*}$ \\
\hline $\mathrm{C} 3$ & $0.9176(4)$ & $0.9204(7)$ & $0.5743(2)$ & $0.0644(16)$ \\
\hline $\mathrm{C} 4$ & $0.8211(4)$ & $0.9051(7)$ & $0.5877(2)$ & $0.0659(16)$ \\
\hline $\mathrm{H} 4 \mathrm{~A}$ & 0.7982 & 0.8048 & 0.5977 & $0.079^{*}$ \\
\hline $\mathrm{C} 5$ & $0.7576(5)$ & $1.0375(7)$ & $0.5865(2)$ & $0.0608(16)$ \\
\hline $\mathrm{H} 5 \mathrm{~A}$ & 0.6926 & 1.0242 & 0.5965 & $0.073^{*}$ \\
\hline C6 & $0.9907(5)$ & $0.7800(8)$ & $0.5769(3)$ & $0.099(2)$ \\
\hline H6A & 0.9574 & 0.6851 & 0.5879 & $0.148^{*}$ \\
\hline H6B & 1.0486 & 0.8062 & 0.5979 & $0.148^{*}$ \\
\hline $\mathrm{H} 6 \mathrm{C}$ & 1.0129 & 0.7588 & 0.5465 & $0.148^{*}$ \\
\hline $\mathrm{C} 7$ & $0.5004(4)$ & $1.1811(8)$ & 0.60763 (19) & $0.0615(16)$ \\
\hline $\mathrm{H} 7 \mathrm{~A}$ & 0.5347 & 1.1927 & 0.6369 & $0.074 *$ \\
\hline $\mathrm{C} 8$ & $0.4124(4)$ & $1.0911(8)$ & $0.60400(19)$ & $0.0647(16)$ \\
\hline H8A & 0.3888 & 1.0433 & 0.6304 & $0.078^{*}$ \\
\hline $\mathrm{C} 9$ & $0.3591(4)$ & $1.0713(6)$ & $0.5617(2)$ & $0.0517(14)$ \\
\hline $\mathrm{C} 10$ & $0.3977(4)$ & $1.1470(7)$ & $0.52470(19)$ & $0.0576(15)$ \\
\hline H10A & 0.3636 & 1.1387 & 0.4953 & $0.069^{*}$ \\
\hline $\mathrm{C} 11$ & $0.4869(4)$ & $1.2357(7)$ & $0.53060(18)$ & $0.0557(14)$ \\
\hline H11A & 0.5113 & 1.2858 & 0.5047 & $0.067 *$ \\
\hline
\end{tabular}




\begin{tabular}{|c|c|c|c|c|}
\hline $\mathrm{C} 12$ & $0.2637(5)$ & $0.9711(8)$ & $0.5554(2)$ & 0.079 (2) \\
\hline $\mathrm{H} 12 \mathrm{~A}$ & 0.2482 & 0.9270 & 0.5849 & $0.119^{*}$ \\
\hline H12B & 0.2735 & 0.8838 & 0.5341 & $0.119^{*}$ \\
\hline $\mathrm{H} 12 \mathrm{C}$ & 0.2082 & 1.0385 & 0.5433 & $0.119^{*}$ \\
\hline $\mathrm{C} 13$ & $0.7765(4)$ & $1.4016(7)$ & $0.66243(17)$ & $0.0480(12)$ \\
\hline $\mathrm{C} 14$ & $0.8311(4)$ & $1.3872(6)$ & $0.70934(17)$ & $0.0482(13)$ \\
\hline $\mathrm{C} 15$ & $0.7898(5)$ & $1.2986(7)$ & 0.74325 (19) & $0.0642(16)$ \\
\hline $\mathrm{H} 15 \mathrm{~A}$ & 0.7272 & 1.2473 & 0.7369 & $0.077^{*}$ \\
\hline $\mathrm{C} 16$ & $0.8406(6)$ & $1.2846(8)$ & $0.7870(2)$ & $0.082(2)$ \\
\hline H16A & 0.8118 & 1.2235 & 0.8098 & $0.099 *$ \\
\hline $\mathrm{C} 17$ & $0.9311(6)$ & $1.3583(9)$ & $0.7970(2)$ & $0.091(2)$ \\
\hline H17A & 0.9640 & 1.3514 & 0.8267 & $0.109^{*}$ \\
\hline $\mathrm{C} 18$ & $0.9740(5)$ & $1.4444(9)$ & $0.7622(2)$ & $0.082(2)$ \\
\hline $\mathrm{H} 18 \mathrm{~A}$ & 1.0379 & 1.4918 & 0.7682 & $0.098^{*}$ \\
\hline C19 & $0.9243(4)$ & $1.4608(7)$ & $0.7192(2)$ & $0.0620(16)$ \\
\hline H19A & 0.9533 & 1.5218 & 0.6964 & $0.074 *$ \\
\hline $\mathrm{C} 20$ & $0.7404(5)$ & $1.4884(7)$ & 0.49409 (19) & $0.0530(14)$ \\
\hline $\mathrm{C} 21$ & $0.7661(4)$ & $1.5138(6)$ & $0.44540(17)$ & $0.0477(13)$ \\
\hline $\mathrm{C} 22$ & $0.8611(5)$ & $1.5703(7)$ & $0.43560(19)$ & $0.0577(15)$ \\
\hline $\mathrm{H} 22 \mathrm{~A}$ & 0.9080 & 1.6017 & 0.4598 & $0.069^{*}$ \\
\hline $\mathrm{C} 23$ & $0.8863(5)$ & $1.5804(8)$ & $0.3902(2)$ & $0.0751(18)$ \\
\hline $\mathrm{H} 23 \mathrm{~A}$ & 0.9501 & 1.6197 & 0.3838 & $0.090^{*}$ \\
\hline $\mathrm{C} 24$ & $0.8195(6)$ & $1.5338(9)$ & $0.3548(2)$ & $0.082(2)$ \\
\hline $\mathrm{H} 24 \mathrm{~A}$ & 0.8377 & 1.5391 & 0.3243 & $0.098^{*}$ \\
\hline $\mathrm{C} 25$ & $0.7243(6)$ & $1.4783(9)$ & $0.3638(2)$ & $0.079(2)$ \\
\hline $\mathrm{H} 25 \mathrm{~A}$ & 0.6780 & 1.4476 & 0.3393 & $0.095^{*}$ \\
\hline $\mathrm{C} 26$ & $0.6978(5)$ & $1.4681(7)$ & 0.40905 (19) & $0.0616(16)$ \\
\hline $\mathrm{H} 26 \mathrm{~A}$ & 0.6335 & 1.4303 & 0.4151 & $0.074 *$ \\
\hline $\mathrm{C} 27$ & $0.2399(7)$ & $0.8450(10)$ & $0.7259(3)$ & $0.096(2)$ \\
\hline $\mathrm{H} 27 \mathrm{~A}$ & 0.2923 & 0.7764 & 0.7373 & $0.115^{*}$ \\
\hline $\mathrm{C} 28$ & $0.1511(8)$ & $0.8373(10)$ & $0.7445(3)$ & $0.099(3)$ \\
\hline $\mathrm{H} 28 \mathrm{~A}$ & 0.1444 & 0.7643 & 0.7687 & $0.119^{*}$ \\
\hline $\mathrm{C} 29$ & $0.0706(7)$ & $0.9290(12)$ & $0.7302(4)$ & $0.116(3)$ \\
\hline $\mathrm{C} 30$ & $0.0847(8)$ & $1.0329(11)$ & $0.6939(4)$ & $0.116(3)$ \\
\hline $\mathrm{H} 30 \mathrm{~A}$ & 0.0319 & 1.0986 & 0.6814 & $0.140^{*}$ \\
\hline C31 & $0.1787(10)$ & $1.0366(11)$ & $0.6770(3)$ & $0.117(3)$ \\
\hline $\mathrm{H} 31 \mathrm{~A}$ & 0.1883 & 1.1092 & 0.6529 & $0.141^{*}$ \\
\hline $\mathrm{C} 32$ & $-0.0293(9)$ & $0.9161(14)$ & $0.7502(6)$ & $0.264(10)$ \\
\hline $\mathrm{H} 32 \mathrm{~A}$ & -0.0248 & 0.8383 & 0.7751 & $0.396^{*}$ \\
\hline H32B & -0.0799 & 0.8811 & 0.7264 & $0.396^{*}$ \\
\hline $\mathrm{H} 32 \mathrm{C}$ & -0.0481 & 1.0204 & 0.7619 & $0.396^{*}$ \\
\hline
\end{tabular}

Atomic displacement parameters $\left(\AA^{2}\right)$

$\begin{array}{lllllll} & U^{11} & U^{22} & U^{33} & U^{12} & U^{13} & U^{23} \\ \text { In1 } & 0.0420(2) & 0.0519(2) & 0.0459(2) & -0.0073(2) & -0.00168(15) & 0.00058(19) \\ \text { C12 } & 0.0544(9) & 0.0605(9) & 0.0617(8) & 0.0047(7) & -0.0014(7) & -0.0033(7) \\ \text { O1 } & 0.039(2) & 0.079(3) & 0.049(2) & -0.011(2) & -0.0055(17) & -0.0019(19)\end{array}$




\begin{tabular}{|c|c|c|c|c|c|c|}
\hline $\mathrm{O} 2$ & $0.053(2)$ & $0.062(2)$ & $0.050(2)$ & $-0.010(2)$ & $-0.0013(18)$ & $0.0047(18)$ \\
\hline $\mathrm{O} 3$ & $0.053(2)$ & $0.072(3)$ & $0.052(2)$ & $-0.010(2)$ & $0.0122(18)$ & $0.004(2)$ \\
\hline $\mathrm{O} 4$ & $0.065(3)$ & $0.060(3)$ & $0.055(2)$ & $-0.010(2)$ & $0.002(2)$ & $0.0003(18)$ \\
\hline N1 & $0.029(2)$ & $0.047(3)$ & $0.054(3)$ & -0.008 (2) & $0.002(2)$ & $0.003(2)$ \\
\hline $\mathrm{N} 2$ & $0.038(2)$ & 0.053 & $0.047(2)$ & $-0.004(2)$ & $0.000(2)$ & $0.001(2)$ \\
\hline N3 & $0.101(5)$ & $0.100(5)$ & $0.111(5)$ & 0.008 & 0.015 & $0.016(4)$ \\
\hline $\mathrm{C} 1$ & $0.049(4)$ & $0.056(4)$ & $0.086(4)$ & -0.009 (3) & 0.004 (3) & $0.006(3)$ \\
\hline $\mathrm{C} 2$ & $0.044(4)$ & 0.055 & $0.122(6)$ & $-0.006(3)$ & $0.012(4)$ & $-0.001(4)$ \\
\hline $\mathrm{C} 3$ & $0.048(4)$ & 0.045 & $0.098(5)$ & -0.004 (3) & $-0.011(3)$ & $-0.012(3)$ \\
\hline $\mathrm{C} 4$ & $0.052(4)$ & $0.044(3)$ & $0.101(5)$ & $-0.008(3)$ & 0.000 & $-0.002(3)$ \\
\hline $\mathrm{C} 5$ & $0.043(4)$ & $0.057(4)$ & $0.084(4)$ & -0.010 & 0.013 & $-0.005(3)$ \\
\hline C6 & $0.067(5)$ & $0.051(4)$ & $0.177(8)$ & 0.011 & $-0.003(5)$ & $0.002(4)$ \\
\hline $\mathrm{C} 7$ & $0.044(4)$ & $0.092(5)$ & $0.046(3)$ & $-0.013(3)$ & -0.008 (3) & 0.005 (3) \\
\hline $\mathrm{C} 8$ & $0.048(4)$ & $0.085(5)$ & $0.061(4)$ & $-0.016(4)$ & $0.002(3)$ & 0.018 \\
\hline C9 & $0.040(3)$ & $0.040(3)$ & $0.074(4)$ & -0.003 & $0.001(3)$ & 0.001 \\
\hline $\mathrm{C} 10$ & $0.044(3)$ & 0.068 (4) & 0.059 (3) & -0.014 (3) & -0.004 (3) & $0.001(3)$ \\
\hline C11 & $0.054(4)$ & $0.067(4)$ & $0.045(3)$ & $-0.014(3)$ & $-0.004(3)$ & 0.007 (3) \\
\hline $\mathrm{C} 12$ & $0.058(4)$ & $0.080(5)$ & $0.100(5)$ & $-0.031(4)$ & $-0.001(4)$ & 0.000 \\
\hline $\mathrm{C} 13$ & $0.045(3)$ & 0.050 & 0.048 (3) & 0.000 & $-0.001(2)$ & $-0.002(3)$ \\
\hline $\mathrm{C} 14$ & $0.047(3)$ & 0.050 & $0.046(3)$ & $0.001(3)$ & $-0.003(2)$ & $-0.001(2)$ \\
\hline C15 & $0.061(4)$ & $0.071(4)$ & 0.059 (4) & $-0.011(3)$ & $-0.012(3)$ & $0.007(3)$ \\
\hline C16 & $0.098(6)$ & $0.091(5)$ & $0.055(4)$ & $-0.020(5)$ & -0.009 (4) & 0.019 (4) \\
\hline $\mathrm{C} 17$ & $0.111(6)$ & $0.096(6)$ & 0.059 (4) & $-0.012(5)$ & $-0.038(4)$ & $0.007(4)$ \\
\hline $\mathrm{C} 18$ & $0.061(4)$ & $0.094(6)$ & $0.086(5)$ & -0.023 & -0.024 & -0.003 \\
\hline $\mathrm{C} 19$ & $0.054(4)$ & $0.071(4)$ & $0.059(4)$ & $-0.012(3)$ & -0.005 (3) & 0.001 \\
\hline $\mathrm{C} 20$ & $0.057(4)$ & 0.045 & $0.057(4)$ & 0.006 & 0.005 & 0.003 \\
\hline C21 & $0.056(4)$ & 0.039 & 0.049 (3) & 0.003 & 0.005 & $0.006(2)$ \\
\hline $\mathrm{C} 22$ & $0.062(4)$ & 0.053 & $0.059(3)$ & $-0.007(3)$ & 0.009 (3) & 0.008 \\
\hline $\mathrm{C} 23$ & $0.068(4)$ & $0.080(5)$ & $0.080(5)$ & $-0.002(4)$ & 0.025 & $0.016(4)$ \\
\hline $\mathrm{C} 24$ & $0.102(6)$ & $0.088(5)$ & $0.058(4)$ & $0.003(4)$ & $0.021(4)$ & $0.012(4)$ \\
\hline $\mathrm{C} 25$ & $0.091(6)$ & $0.094(5)$ & 0.049 (4) & $-0.006(4)$ & $-0.006(4)$ & 0.003 \\
\hline $\mathrm{C} 26$ & $0.059(4)$ & $0.066(4)$ & $0.060(4)$ & -0.009 (3) & $0.005(3)$ & $0.002(3)$ \\
\hline $\mathrm{C} 27$ & $0.101(7)$ & $0.087(6)$ & $0.100(6)$ & $0.003(5)$ & $0.003(5)$ & $0.008(5)$ \\
\hline $\mathrm{C} 28$ & $0.114(7)$ & $0.083(6)$ & $0.105(6)$ & $-0.018(6)$ & $0.038(6)$ & $0.004(5)$ \\
\hline $\mathrm{C} 29$ & $0.073(6)$ & $0.077(6)$ & 0.204 (11) & $0.000(5)$ & $0.044(7)$ & $-0.013(7)$ \\
\hline C30 & $0.096(7)$ & $0.082(6)$ & $0.167(10)$ & $0.020(6)$ & $-0.020(7)$ & $-0.005(6)$ \\
\hline C31 & $0.168(11)$ & $0.094(7)$ & $0.088(6)$ & $0.007(7)$ & $0.001(7)$ & $0.011(5)$ \\
\hline C32 & 0.149 (11) & $0.122(10)$ & $0.55(3)$ & -0.019 (8) & $0.191(15)$ & $-0.032(13)$ \\
\hline
\end{tabular}

Geometric parameters $\left(\AA,{ }^{\circ}\right)$

$$
\begin{aligned}
& \text { In1-O3 } \\
& \text { In1-O1 } \\
& \text { In1-N2 } \\
& \text { In1-O2 } \\
& \text { In1-N1 } \\
& \text { In1-Cl2 } \\
& \text { In1-O4 } \\
& \text { In1-C13 }
\end{aligned}
$$

$2.212(3)$
$2.274(3)$
$2.286(4)$
$2.292(4)$
$2.312(4)$
$2.4132(15)$
$2.417(4)$
$2.639(5)$

$\mathrm{C} 7-\mathrm{C} 8$
$\mathrm{C} 8-\mathrm{C} 9$
$\mathrm{C} 9-\mathrm{C} 10$
$\mathrm{C} 9-\mathrm{C} 12$
$\mathrm{C} 10-\mathrm{C} 11$
$\mathrm{C} 13-\mathrm{C} 14$
$\mathrm{C} 14-\mathrm{C} 15$
$\mathrm{C} 14-\mathrm{C} 19$

$1.371(7)$

$1.366(7)$

$1.365(7)$

$1.501(7)$

$1.381(7)$

$1.484(7)$

$1.364(7)$

$1.376(8)$ 


\begin{tabular}{|c|c|c|c|}
\hline $\mathrm{In} 1-\mathrm{C} 20$ & $2.667(6)$ & $\mathrm{C} 15-\mathrm{C} 16$ & $1.384(8)$ \\
\hline $\mathrm{O} 1-\mathrm{C} 13$ & $1.261(6)$ & $\mathrm{C} 16-\mathrm{C} 17$ & $1.347(9)$ \\
\hline $\mathrm{O} 2-\mathrm{C} 13$ & $1.259(6)$ & $\mathrm{C} 17-\mathrm{C} 18$ & $1.382(9)$ \\
\hline $\mathrm{O} 3-\mathrm{C} 20$ & $1.248(6)$ & $\mathrm{C} 18-\mathrm{C} 19$ & $1.362(8)$ \\
\hline $\mathrm{O} 4-\mathrm{C} 20$ & $1.249(6)$ & $\mathrm{C} 20-\mathrm{C} 21$ & $1.482(7)$ \\
\hline $\mathrm{N} 1-\mathrm{C} 1$ & $1.319(7)$ & $\mathrm{C} 21-\mathrm{C} 22$ & $1.382(7)$ \\
\hline $\mathrm{N} 1-\mathrm{C} 5$ & $1.331(7)$ & $\mathrm{C} 21-\mathrm{C} 26$ & $1.378(7)$ \\
\hline $\mathrm{N} 2-\mathrm{C} 7$ & $1.330(6)$ & $\mathrm{C} 22-\mathrm{C} 23$ & $1.377(8)$ \\
\hline $\mathrm{N} 2-\mathrm{C} 11$ & $1.330(6)$ & $\mathrm{C} 23-\mathrm{C} 24$ & $1.348(9)$ \\
\hline N3-C27 & $1.308(9)$ & $\mathrm{C} 24-\mathrm{C} 25$ & $1.375(9)$ \\
\hline $\mathrm{N} 3-\mathrm{C} 31$ & $1.318(11)$ & $\mathrm{C} 25-\mathrm{C} 26$ & $1.378(8)$ \\
\hline $\mathrm{C} 1-\mathrm{C} 2$ & $1.374(8)$ & $\mathrm{C} 27-\mathrm{C} 28$ & $1.324(10)$ \\
\hline $\mathrm{C} 2-\mathrm{C} 3$ & $1.375(8)$ & $\mathrm{C} 28-\mathrm{C} 29$ & $1.338(12)$ \\
\hline $\mathrm{C} 3-\mathrm{C} 4$ & $1.362(8)$ & $\mathrm{C} 29-\mathrm{C} 30$ & $1.372(12)$ \\
\hline $\mathrm{C} 3-\mathrm{C} 6$ & $1.500(8)$ & $\mathrm{C} 29-\mathrm{C} 32$ & $1.479(12)$ \\
\hline $\mathrm{C} 4-\mathrm{C} 5$ & $1.370(8)$ & $\mathrm{C} 30-\mathrm{C} 31$ & $1.364(12)$ \\
\hline $\mathrm{O} 3-\mathrm{In} 1-\mathrm{O} 1$ & $162.40(15)$ & $\mathrm{C} 3-\mathrm{C} 2-\mathrm{C} 1$ & $119.4(6)$ \\
\hline $\mathrm{O} 3-\mathrm{In} 1-\mathrm{N} 2$ & $82.98(14)$ & $\mathrm{C} 4-\mathrm{C} 3-\mathrm{C} 2$ & $117.0(6)$ \\
\hline $\mathrm{O} 1-\mathrm{In} 1-\mathrm{N} 2$ & $83.94(14)$ & $\mathrm{C} 4-\mathrm{C} 3-\mathrm{C} 6$ & $121.6(6)$ \\
\hline $\mathrm{O} 3-\mathrm{In} 1-\mathrm{O} 2$ & $134.10(14)$ & $\mathrm{C} 2-\mathrm{C} 3-\mathrm{C} 6$ & $121.4(6)$ \\
\hline $\mathrm{O} 1-\mathrm{In} 1-\mathrm{O} 2$ & $56.99(12)$ & $\mathrm{C} 3-\mathrm{C} 4-\mathrm{C} 5$ & $120.0(6)$ \\
\hline $\mathrm{N} 2-\mathrm{In} 1-\mathrm{O} 2$ & $140.78(14)$ & $\mathrm{N} 1-\mathrm{C} 5-\mathrm{C} 4$ & $123.7(5)$ \\
\hline $\mathrm{O} 3-\mathrm{In} 1-\mathrm{N} 1$ & $86.83(14)$ & $\mathrm{N} 2-\mathrm{C} 7-\mathrm{C} 8$ & $123.8(5)$ \\
\hline $\mathrm{O} 1-\mathrm{In} 1-\mathrm{N} 1$ & $81.50(14)$ & $\mathrm{C} 7-\mathrm{C} 8-\mathrm{C} 9$ & $120.2(5)$ \\
\hline $\mathrm{N} 2-\mathrm{In} 1-\mathrm{N} 1$ & $90.28(15)$ & $\mathrm{C} 8-\mathrm{C} 9-\mathrm{C} 10$ & $116.5(5)$ \\
\hline $\mathrm{O} 2-\mathrm{In} 1-\mathrm{N} 1$ & $81.33(14)$ & $\mathrm{C} 8-\mathrm{C} 9-\mathrm{C} 12$ & $122.6(5)$ \\
\hline $\mathrm{O} 3-\mathrm{In} 1-\mathrm{Cl} 2$ & 97.07 (11) & $\mathrm{C} 10-\mathrm{C} 9-\mathrm{C} 12$ & $120.9(5)$ \\
\hline $\mathrm{O} 1-\mathrm{In} 1-\mathrm{Cl} 2$ & $95.43(11)$ & $\mathrm{C} 9-\mathrm{C} 10-\mathrm{C} 11$ & $120.5(5)$ \\
\hline $\mathrm{N} 2-\mathrm{In} 1-\mathrm{Cl} 2$ & $93.44(11)$ & $\mathrm{N} 2-\mathrm{C} 11-\mathrm{C} 10$ & $123.0(5)$ \\
\hline $\mathrm{O} 2-\mathrm{In} 1-\mathrm{Cl} 2$ & $93.60(10)$ & $\mathrm{O} 2-\mathrm{C} 13-\mathrm{O} 1$ & $119.6(5)$ \\
\hline $\mathrm{N} 1-\mathrm{In} 1-\mathrm{Cl} 2$ & $174.91(10)$ & $\mathrm{O} 2-\mathrm{C} 13-\mathrm{C} 14$ & $120.5(5)$ \\
\hline $\mathrm{O} 3-\mathrm{In} 1-\mathrm{O} 4$ & $55.57(13)$ & $\mathrm{O} 1-\mathrm{C} 13-\mathrm{C} 14$ & $119.9(5)$ \\
\hline $\mathrm{O} 1-\mathrm{In} 1-\mathrm{O} 4$ & $135.57(13)$ & $\mathrm{O} 2-\mathrm{C} 13-\mathrm{In} 1$ & $60.2(3)$ \\
\hline $\mathrm{N} 2-\mathrm{In} 1-\mathrm{O} 4$ & $138.45(14)$ & $\mathrm{O} 1-\mathrm{C} 13-\mathrm{In} 1$ & $59.5(3)$ \\
\hline $\mathrm{O} 2-\mathrm{In} 1-\mathrm{O} 4$ & $79.23(13)$ & $\mathrm{C} 14-\mathrm{C} 13-\mathrm{In} 1$ & $177.1(4)$ \\
\hline $\mathrm{N} 1-\mathrm{In} 1-\mathrm{O} 4$ & $85.11(14)$ & $\mathrm{C} 15-\mathrm{C} 14-\mathrm{C} 19$ & $119.0(5)$ \\
\hline $\mathrm{Cl} 2-\mathrm{In} 1-\mathrm{O} 4$ & $94.37(10)$ & $\mathrm{C} 15-\mathrm{C} 14-\mathrm{C} 13$ & $120.2(5)$ \\
\hline $\mathrm{O} 3-\mathrm{In} 1-\mathrm{C} 13$ & $159.22(15)$ & $\mathrm{C} 19-\mathrm{C} 14-\mathrm{C} 13$ & $120.8(5)$ \\
\hline $\mathrm{O} 1-\mathrm{In} 1-\mathrm{C} 13$ & $28.52(14)$ & $\mathrm{C} 14-\mathrm{C} 15-\mathrm{C} 16$ & $120.3(6)$ \\
\hline $\mathrm{N} 2-\mathrm{In} 1-\mathrm{C} 13$ & $112.33(16)$ & $\mathrm{C} 17-\mathrm{C} 16-\mathrm{C} 15$ & $120.9(6)$ \\
\hline $\mathrm{O} 2-\mathrm{In} 1-\mathrm{C} 13$ & $28.50(14)$ & $\mathrm{C} 16-\mathrm{C} 17-\mathrm{C} 18$ & $118.7(6)$ \\
\hline $\mathrm{N} 1-\mathrm{In} 1-\mathrm{C} 13$ & $79.40(15)$ & $\mathrm{C} 19-\mathrm{C} 18-\mathrm{C} 17$ & $121.0(6)$ \\
\hline $\mathrm{C} 12-\mathrm{In} 1-\mathrm{C} 13$ & $95.96(12)$ & $\mathrm{C} 18-\mathrm{C} 19-\mathrm{C} 14$ & $120.0(6)$ \\
\hline $\mathrm{O} 4-\mathrm{In} 1-\mathrm{C} 13$ & $107.33(16)$ & $\mathrm{O} 4-\mathrm{C} 20-\mathrm{O} 3$ & $120.2(5)$ \\
\hline $\mathrm{O} 3-\mathrm{In} 1-\mathrm{C} 20$ & $27.68(15)$ & $\mathrm{O} 4-\mathrm{C} 20-\mathrm{C} 21$ & $121.1(5)$ \\
\hline $\mathrm{O} 1-\mathrm{In} 1-\mathrm{C} 20$ & $160.17(16)$ & $\mathrm{O} 3-\mathrm{C} 20-\mathrm{C} 21$ & $118.7(5)$ \\
\hline $\mathrm{N} 2-\mathrm{In} 1-\mathrm{C} 20$ & $110.58(17)$ & $\mathrm{O} 4-\mathrm{C} 20-\mathrm{In} 1$ & $64.8(3)$ \\
\hline $\mathrm{O} 2-\mathrm{In} 1-\mathrm{C} 20$ & $106.74(17)$ & $\mathrm{O} 3-\mathrm{C} 20-\mathrm{In} 1$ & $55.4(3)$ \\
\hline $\mathrm{N} 1-\mathrm{In} 1-\mathrm{C} 20$ & $84.89(15)$ & $\mathrm{C} 21-\mathrm{C} 20-\mathrm{In} 1$ & $173.4(4)$ \\
\hline
\end{tabular}




\begin{tabular}{|c|c|}
\hline $\mathrm{C} 12-\mathrm{In} 1-\mathrm{C} 20$ & $97.02(12)$ \\
\hline $\mathrm{O} 4-\mathrm{In} 1-\mathrm{C} 20$ & $27.90(14)$ \\
\hline $\mathrm{C} 13-\mathrm{In} 1-\mathrm{C} 20$ & $134.10(19)$ \\
\hline $\mathrm{C} 13-\mathrm{O} 1-\mathrm{In} 1$ & $92.0(3)$ \\
\hline $\mathrm{C} 13-\mathrm{O} 2-\mathrm{In} 1$ & $91.3(3)$ \\
\hline $\mathrm{C} 20-\mathrm{O} 3-\mathrm{In} 1$ & $96.9(3)$ \\
\hline $\mathrm{C} 20-\mathrm{O} 4-\mathrm{In} 1$ & $87.3(3)$ \\
\hline $\mathrm{C} 1-\mathrm{N} 1-\mathrm{C} 5$ & $115.9(5)$ \\
\hline $\mathrm{C} 1-\mathrm{N} 1-\mathrm{In} 1$ & $120.6(4)$ \\
\hline $\mathrm{C} 5-\mathrm{N} 1-\mathrm{In} 1$ & $122.9(4)$ \\
\hline $\mathrm{C} 7-\mathrm{N} 2-\mathrm{C} 11$ & $116.0(5)$ \\
\hline $\mathrm{C} 7-\mathrm{N} 2-\mathrm{In} 1$ & $123.8(4)$ \\
\hline $\mathrm{C} 11-\mathrm{N} 2-\mathrm{In} 1$ & $120.1(3)$ \\
\hline $\mathrm{C} 27-\mathrm{N} 3-\mathrm{C} 31$ & $115.5(8)$ \\
\hline $\mathrm{N} 1-\mathrm{C} 1-\mathrm{C} 2$ & $124.0(5)$ \\
\hline $\mathrm{O} 3-\mathrm{In} 1-\mathrm{O} 1-\mathrm{C} 13$ & $132.4(4)$ \\
\hline $\mathrm{N} 2-\mathrm{In} 1-\mathrm{O} 1-\mathrm{C} 13$ & $174.6(3)$ \\
\hline $\mathrm{O} 2-\mathrm{In} 1-\mathrm{O} 1-\mathrm{C} 13$ & $-1.7(3)$ \\
\hline $\mathrm{N} 1-\mathrm{In} 1-\mathrm{O} 1-\mathrm{C} 13$ & $83.4(3)$ \\
\hline $\mathrm{Cl} 2-\mathrm{In} 1-\mathrm{O} 1-\mathrm{C} 13$ & $-92.5(3)$ \\
\hline $\mathrm{O} 4-\mathrm{In} 1-\mathrm{O} 1-\mathrm{C} 13$ & $9.4(4)$ \\
\hline $\mathrm{C} 20-\mathrm{In} 1-\mathrm{O} 1-\mathrm{C} 13$ & $36.2(6)$ \\
\hline $\mathrm{O} 3-\mathrm{In} 1-\mathrm{O} 2-\mathrm{C} 13$ & $-160.7(3)$ \\
\hline $\mathrm{O} 1-\mathrm{In} 1-\mathrm{O} 2-\mathrm{C} 13$ & $1.7(3)$ \\
\hline $\mathrm{N} 2-\mathrm{In} 1-\mathrm{O} 2-\mathrm{C} 13$ & $-4.1(4)$ \\
\hline $\mathrm{N} 1-\mathrm{In} 1-\mathrm{O} 2-\mathrm{C} 13$ & $-83.7(3)$ \\
\hline $\mathrm{Cl} 2-\mathrm{In} 1-\mathrm{O} 2-\mathrm{C} 13$ & $95.9(3)$ \\
\hline $\mathrm{O} 4-\mathrm{In} 1-\mathrm{O} 2-\mathrm{C} 13$ & $-170.4(3)$ \\
\hline $\mathrm{C} 20-\mathrm{In} 1-\mathrm{O} 2-\mathrm{C} 13$ & $-165.7(3)$ \\
\hline $\mathrm{O} 1-\mathrm{In} 1-\mathrm{O} 3-\mathrm{C} 20$ & $-133.4(5)$ \\
\hline $\mathrm{N} 2-\mathrm{In} 1-\mathrm{O} 3-\mathrm{C} 20$ & $-175.7(3)$ \\
\hline $\mathrm{O} 2-\mathrm{In} 1-\mathrm{O} 3-\mathrm{C} 20$ & $-10.4(4)$ \\
\hline $\mathrm{N} 1-\mathrm{In} 1-\mathrm{O} 3-\mathrm{C} 20$ & $-85.1(3)$ \\
\hline $\mathrm{Cl} 2-\mathrm{In} 1-\mathrm{O} 3-\mathrm{C} 20$ & $91.7(3)$ \\
\hline $\mathrm{O} 4-\mathrm{In} 1-\mathrm{O} 3-\mathrm{C} 20$ & $1.2(3)$ \\
\hline $\mathrm{C} 13-\mathrm{In} 1-\mathrm{O} 3-\mathrm{C} 20$ & $-36.8(6)$ \\
\hline $\mathrm{O} 3-\mathrm{In} 1-\mathrm{O} 4-\mathrm{C} 20$ & $-1.2(3)$ \\
\hline $\mathrm{O} 1-\mathrm{In} 1-\mathrm{O} 4-\mathrm{C} 20$ & $160.9(3)$ \\
\hline $\mathrm{N} 2-\mathrm{In} 1-\mathrm{O} 4-\mathrm{C} 20$ & $3.4(4)$ \\
\hline $\mathrm{O} 2-\mathrm{In} 1-\mathrm{O} 4-\mathrm{C} 20$ & $170.4(3)$ \\
\hline $\mathrm{N} 1-\mathrm{In} 1-\mathrm{O} 4-\mathrm{C} 20$ & $88.3(3)$ \\
\hline $\mathrm{Cl} 2-\mathrm{In} 1-\mathrm{O} 4-\mathrm{C} 20$ & $-96.8(3)$ \\
\hline $\mathrm{C} 13-\mathrm{In} 1-\mathrm{O} 4-\mathrm{C} 20$ & $165.6(3)$ \\
\hline $\mathrm{O} 3-\mathrm{In} 1-\mathrm{N} 1-\mathrm{C} 1$ & $76.1(4)$ \\
\hline $\mathrm{O} 1-\mathrm{In} 1-\mathrm{N} 1-\mathrm{C} 1$ & $-117.1(4)$ \\
\hline $\mathrm{N} 2-\mathrm{In} 1-\mathrm{N} 1-\mathrm{C} 1$ & $159.1(4)$ \\
\hline $\mathrm{O} 2-\mathrm{In} 1-\mathrm{N} 1-\mathrm{C} 1$ & $-59.4(4)$ \\
\hline $\mathrm{C} 12-\mathrm{In} 1-\mathrm{N} 1-\mathrm{C} 1$ & $-63.9(13)$ \\
\hline $\mathrm{O} 4-\mathrm{In} 1-\mathrm{N} 1-\mathrm{C} 1$ & $20.4(4)$ \\
\hline
\end{tabular}

\begin{tabular}{|c|c|}
\hline $\mathrm{C} 22-\mathrm{C} 21-\mathrm{C} 26$ & $118.9(5)$ \\
\hline $\mathrm{C} 22-\mathrm{C} 21-\mathrm{C} 20$ & $121.1(5)$ \\
\hline $\mathrm{C} 26-\mathrm{C} 21-\mathrm{C} 20$ & $119.8(5)$ \\
\hline $\mathrm{C} 21-\mathrm{C} 22-\mathrm{C} 23$ & $120.2(6)$ \\
\hline $\mathrm{C} 24-\mathrm{C} 23-\mathrm{C} 22$ & $120.6(6)$ \\
\hline $\mathrm{C} 23-\mathrm{C} 24-\mathrm{C} 25$ & $120.1(6)$ \\
\hline $\mathrm{C} 24-\mathrm{C} 25-\mathrm{C} 26$ & $119.9(6)$ \\
\hline $\mathrm{C} 25-\mathrm{C} 26-\mathrm{C} 21$ & $120.2(6)$ \\
\hline $\mathrm{N} 3-\mathrm{C} 27-\mathrm{C} 28$ & $122.5(9)$ \\
\hline $\mathrm{C} 27-\mathrm{C} 28-\mathrm{C} 29$ & $123.5(9)$ \\
\hline $\mathrm{C} 28-\mathrm{C} 29-\mathrm{C} 30$ & $115.7(9)$ \\
\hline $\mathrm{C} 28-\mathrm{C} 29-\mathrm{C} 32$ & $123.1(12)$ \\
\hline $\mathrm{C} 30-\mathrm{C} 29-\mathrm{C} 32$ & $121.1(12)$ \\
\hline $\mathrm{C} 31-\mathrm{C} 30-\mathrm{C} 29$ & $117.8(9)$ \\
\hline $\mathrm{N} 3-\mathrm{C} 31-\mathrm{C} 30$ & $125.1(9)$ \\
\hline $\mathrm{O} 3-\mathrm{In} 1-\mathrm{C} 13-\mathrm{O} 2$ & $42.0(6)$ \\
\hline $\mathrm{O} 1-\mathrm{In} 1-\mathrm{C} 13-\mathrm{O} 2$ & $-177.0(5)$ \\
\hline $\mathrm{N} 2-\mathrm{In} 1-\mathrm{C} 13-\mathrm{O} 2$ & $177.2(3)$ \\
\hline $\mathrm{N} 1-\mathrm{In} 1-\mathrm{C} 13-\mathrm{O} 2$ & $91.3(3)$ \\
\hline $\mathrm{C} 12-\mathrm{In} 1-\mathrm{C} 13-\mathrm{O} 2$ & $-86.6(3)$ \\
\hline $\mathrm{O} 4-\mathrm{In} 1-\mathrm{C} 13-\mathrm{O} 2$ & $9.9(3)$ \\
\hline $\mathrm{C} 20-\mathrm{In} 1-\mathrm{C} 13-\mathrm{O} 2$ & $19.2(4)$ \\
\hline $\mathrm{O} 3-\mathrm{In} 1-\mathrm{C} 13-\mathrm{O} 1$ & $-141.0(4)$ \\
\hline $\mathrm{N} 2-\mathrm{In} 1-\mathrm{C} 13-\mathrm{O} 1$ & $-5.8(4)$ \\
\hline $\mathrm{O} 2-\mathrm{In} 1-\mathrm{C} 13-\mathrm{O} 1$ & $177.0(5)$ \\
\hline $\mathrm{N} 1-\mathrm{In} 1-\mathrm{C} 13-\mathrm{O} 1$ & $-91.7(3)$ \\
\hline $\mathrm{Cl} 2-\mathrm{In} 1-\mathrm{C} 13-\mathrm{O} 1$ & $90.4(3)$ \\
\hline $\mathrm{O} 4-\mathrm{In} 1-\mathrm{C} 13-\mathrm{O} 1$ & $-173.1(3)$ \\
\hline $\mathrm{C} 20-\mathrm{In} 1-\mathrm{C} 13-\mathrm{O} 1$ & $-163.8(3)$ \\
\hline $\mathrm{O} 3-\mathrm{In} 1-\mathrm{C} 13-\mathrm{C} 14$ & $-63(8)$ \\
\hline $\mathrm{O} 1-\mathrm{In} 1-\mathrm{C} 13-\mathrm{C} 14$ & $78(8)$ \\
\hline $\mathrm{N} 2-\mathrm{In} 1-\mathrm{C} 13-\mathrm{C} 14$ & $72(8)$ \\
\hline $\mathrm{O} 2-\mathrm{In} 1-\mathrm{C} 13-\mathrm{C} 14$ & $-105(8)$ \\
\hline $\mathrm{N} 1-\mathrm{In} 1-\mathrm{C} 13-\mathrm{C} 14$ & $-14(8)$ \\
\hline $\mathrm{Cl} 2-\mathrm{In} 1-\mathrm{C} 13-\mathrm{C} 14$ & $168(8)$ \\
\hline $\mathrm{O} 4-\mathrm{In} 1-\mathrm{C} 13-\mathrm{C} 14$ & $-95(8)$ \\
\hline $\mathrm{C} 20-\mathrm{In} 1-\mathrm{C} 13-\mathrm{C} 14$ & $-86(8)$ \\
\hline $\mathrm{O} 2-\mathrm{C} 13-\mathrm{C} 14-\mathrm{C} 15$ & $-180.0(5)$ \\
\hline $\mathrm{O} 1-\mathrm{C} 13-\mathrm{C} 14-\mathrm{C} 15$ & $-0.2(8)$ \\
\hline $\mathrm{In} 1-\mathrm{C} 13-\mathrm{C} 14-\mathrm{C} 15$ & $-77(8)$ \\
\hline $\mathrm{O} 2-\mathrm{C} 13-\mathrm{C} 14-\mathrm{C} 19$ & $-0.7(8)$ \\
\hline $\mathrm{O} 1-\mathrm{C} 13-\mathrm{C} 14-\mathrm{C} 19$ & $179.0(5)$ \\
\hline $\mathrm{In} 1-\mathrm{C} 13-\mathrm{C} 14-\mathrm{C} 19$ & $103(8)$ \\
\hline $\mathrm{C} 19-\mathrm{C} 14-\mathrm{C} 15-\mathrm{C} 16$ & $0.7(9)$ \\
\hline $\mathrm{C} 13-\mathrm{C} 14-\mathrm{C} 15-\mathrm{C} 16$ & $179.9(6)$ \\
\hline $\mathrm{C} 14-\mathrm{C} 15-\mathrm{C} 16-\mathrm{C} 17$ & $0.3(11)$ \\
\hline $\mathrm{C} 15-\mathrm{C} 16-\mathrm{C} 17-\mathrm{C} 18$ & $-2.0(12)$ \\
\hline $\mathrm{C} 16-\mathrm{C} 17-\mathrm{C} 18-\mathrm{C} 19$ & $2.8(12)$ \\
\hline $\mathrm{C} 17-\mathrm{C} 18-\mathrm{C} 19-\mathrm{C} 14$ & $-1.9(11)$ \\
\hline
\end{tabular}




\begin{tabular}{|c|c|c|c|}
\hline $\mathrm{C} 13-\mathrm{In} 1-\mathrm{N} 1-\mathrm{C} 1$ & $-88.2(4)$ & $\mathrm{C} 15-\mathrm{C} 14-\mathrm{C} 19-\mathrm{C} 18$ & $0.2(9)$ \\
\hline $\mathrm{C} 20-\mathrm{In} 1-\mathrm{N} 1-\mathrm{C} 1$ & $48.4(4)$ & $\mathrm{C} 13-\mathrm{C} 14-\mathrm{C} 19-\mathrm{C} 18$ & $-179.1(5)$ \\
\hline $\mathrm{O} 3-\mathrm{In} 1-\mathrm{N} 1-\mathrm{C} 5$ & $-113.3(4)$ & $\mathrm{In} 1-\mathrm{O} 4-\mathrm{C} 20-\mathrm{O} 3$ & $2.0(5)$ \\
\hline $\mathrm{O} 1-\mathrm{In} 1-\mathrm{N} 1-\mathrm{C} 5$ & $53.5(4)$ & $\mathrm{In} 1-\mathrm{O} 4-\mathrm{C} 20-\mathrm{C} 21$ & $-176.6(5)$ \\
\hline $\mathrm{N} 2-\mathrm{In} 1-\mathrm{N} 1-\mathrm{C} 5$ & $-30.3(4)$ & $\mathrm{In} 1-\mathrm{O} 3-\mathrm{C} 20-\mathrm{O} 4$ & $-2.2(6)$ \\
\hline $\mathrm{O} 2-\mathrm{In} 1-\mathrm{N} 1-\mathrm{C} 5$ & $111.2(4)$ & $\mathrm{In} 1-\mathrm{O} 3-\mathrm{C} 20-\mathrm{C} 21$ & $176.5(4)$ \\
\hline $\mathrm{C} 12-\mathrm{In} 1-\mathrm{N} 1-\mathrm{C} 5$ & $106.7(12)$ & $\mathrm{O} 3-\mathrm{In} 1-\mathrm{C} 20-\mathrm{O} 4$ & $177.9(5)$ \\
\hline $\mathrm{O} 4-\mathrm{In} 1-\mathrm{N} 1-\mathrm{C} 5$ & $-169.0(4)$ & $\mathrm{O} 1-\mathrm{In} 1-\mathrm{C} 20-\mathrm{O} 4$ & $-42.4(6)$ \\
\hline $\mathrm{C} 13-\mathrm{In} 1-\mathrm{N} 1-\mathrm{C} 5$ & $82.4(4)$ & $\mathrm{N} 2-\mathrm{In} 1-\mathrm{C} 20-\mathrm{O} 4$ & $-177.6(3)$ \\
\hline $\mathrm{C} 20-\mathrm{In} 1-\mathrm{N} 1-\mathrm{C} 5$ & $-140.9(4)$ & $\mathrm{O} 2-\mathrm{In} 1-\mathrm{C} 20-\mathrm{O} 4$ & $-9.8(3)$ \\
\hline $\mathrm{O} 3-\mathrm{In} 1-\mathrm{N} 2-\mathrm{C} 7$ & $174.2(5)$ & $\mathrm{N} 1-\mathrm{In} 1-\mathrm{C} 20-\mathrm{O} 4$ & $-89.2(3)$ \\
\hline $\mathrm{O} 1-\mathrm{In} 1-\mathrm{N} 2-\mathrm{C} 7$ & $6.0(4)$ & $\mathrm{Cl} 2-\mathrm{In} 1-\mathrm{C} 20-\mathrm{O} 4$ & $86.1(3)$ \\
\hline $\mathrm{O} 2-\mathrm{In} 1-\mathrm{N} 2-\mathrm{C} 7$ & $10.8(6)$ & $\mathrm{C} 13-\mathrm{In} 1-\mathrm{C} 20-\mathrm{O} 4$ & $-19.3(4)$ \\
\hline $\mathrm{N} 1-\mathrm{In} 1-\mathrm{N} 2-\mathrm{C} 7$ & $87.4(5)$ & $\mathrm{O} 1-\mathrm{In} 1-\mathrm{C} 20-\mathrm{O} 3$ & $139.7(4)$ \\
\hline $\mathrm{Cl} 2-\mathrm{In} 1-\mathrm{N} 2-\mathrm{C} 7$ & $-89.1(4)$ & $\mathrm{N} 2-\mathrm{In} 1-\mathrm{C} 20-\mathrm{O} 3$ & $4.5(4)$ \\
\hline $\mathrm{O} 4-\mathrm{In} 1-\mathrm{N} 2-\mathrm{C} 7$ & $170.3(4)$ & $\mathrm{O} 2-\mathrm{In} 1-\mathrm{C} 20-\mathrm{O} 3$ & $172.2(3)$ \\
\hline $\mathrm{C} 13-\mathrm{In} 1-\mathrm{N} 2-\mathrm{C} 7$ & $8.7(5)$ & $\mathrm{N} 1-\mathrm{In} 1-\mathrm{C} 20-\mathrm{O} 3$ & $92.9(3)$ \\
\hline $\mathrm{C} 20-\mathrm{In} 1-\mathrm{N} 2-\mathrm{C} 7$ & $172.0(4)$ & $\mathrm{C} 12-\mathrm{In} 1-\mathrm{C} 20-\mathrm{O} 3$ & $-91.8(3)$ \\
\hline $\mathrm{O} 3-\mathrm{In} 1-\mathrm{N} 2-\mathrm{C} 11$ & $-10.2(4)$ & $\mathrm{O} 4-\mathrm{In} 1-\mathrm{C} 20-\mathrm{O} 3$ & $-177.9(5)$ \\
\hline $\mathrm{O} 1-\mathrm{In} 1-\mathrm{N} 2-\mathrm{C} 11$ & $-178.4(4)$ & $\mathrm{C} 13-\mathrm{In} 1-\mathrm{C} 20-\mathrm{O} 3$ & $162.8(3)$ \\
\hline $\mathrm{O} 2-\mathrm{In} 1-\mathrm{N} 2-\mathrm{C} 11$ & $-173.5(4)$ & $\mathrm{O} 3-\mathrm{In} 1-\mathrm{C} 20-\mathrm{C} 21$ & $-28(3)$ \\
\hline $\mathrm{N} 1-\mathrm{In} 1-\mathrm{N} 2-\mathrm{C} 11$ & $-96.9(4)$ & $\mathrm{O} 1-\mathrm{In} 1-\mathrm{C} 20-\mathrm{C} 21$ & $112(3)$ \\
\hline $\mathrm{Cl} 2-\mathrm{In} 1-\mathrm{N} 2-\mathrm{C} 11$ & $86.5(4)$ & $\mathrm{N} 2-\mathrm{In} 1-\mathrm{C} 20-\mathrm{C} 21$ & $-23(4)$ \\
\hline $\mathrm{O} 4-\mathrm{In} 1-\mathrm{N} 2-\mathrm{C} 11$ & $-14.0(5)$ & $\mathrm{O} 2-\mathrm{In} 1-\mathrm{C} 20-\mathrm{C} 21$ & $144(3)$ \\
\hline $\mathrm{C} 13-\mathrm{In} 1-\mathrm{N} 2-\mathrm{C} 11$ & $-175.6(4)$ & $\mathrm{N} 1-\mathrm{In} 1-\mathrm{C} 20-\mathrm{C} 21$ & $65(4)$ \\
\hline $\mathrm{C} 20-\mathrm{In} 1-\mathrm{N} 2-\mathrm{C} 11$ & $-12.3(4)$ & $\mathrm{C} 12-\mathrm{In} 1-\mathrm{C} 20-\mathrm{C} 21$ & $-120(4)$ \\
\hline $\mathrm{C} 5-\mathrm{N} 1-\mathrm{C} 1-\mathrm{C} 2$ & $1.0(9)$ & $\mathrm{O} 4-\mathrm{In} 1-\mathrm{C} 20-\mathrm{C} 21$ & $154(4)$ \\
\hline $\mathrm{In} 1-\mathrm{N} 1-\mathrm{C} 1-\mathrm{C} 2$ & $172.3(5)$ & $\mathrm{C} 13-\mathrm{In} 1-\mathrm{C} 20-\mathrm{C} 21$ & $135(3)$ \\
\hline $\mathrm{N} 1-\mathrm{C} 1-\mathrm{C} 2-\mathrm{C} 3$ & $-0.6(10)$ & $\mathrm{O} 4-\mathrm{C} 20-\mathrm{C} 21-\mathrm{C} 22$ & $11.2(8)$ \\
\hline $\mathrm{C} 1-\mathrm{C} 2-\mathrm{C} 3-\mathrm{C} 4$ & $0.5(10)$ & $\mathrm{O} 3-\mathrm{C} 20-\mathrm{C} 21-\mathrm{C} 22$ & $-167.5(5)$ \\
\hline $\mathrm{C} 1-\mathrm{C} 2-\mathrm{C} 3-\mathrm{C} 6$ & $-178.1(6)$ & $\mathrm{In} 1-\mathrm{C} 20-\mathrm{C} 21-\mathrm{C} 22$ & $-141(3)$ \\
\hline $\mathrm{C} 2-\mathrm{C} 3-\mathrm{C} 4-\mathrm{C} 5$ & $-0.9(9)$ & $\mathrm{O} 4-\mathrm{C} 20-\mathrm{C} 21-\mathrm{C} 26$ & $-174.2(5)$ \\
\hline $\mathrm{C} 6-\mathrm{C} 3-\mathrm{C} 4-\mathrm{C} 5$ & $177.7(6)$ & $\mathrm{O} 3-\mathrm{C} 20-\mathrm{C} 21-\mathrm{C} 26$ & $7.1(8)$ \\
\hline $\mathrm{C} 1-\mathrm{N} 1-\mathrm{C} 5-\mathrm{C} 4$ & $-1.4(8)$ & $\mathrm{In} 1-\mathrm{C} 20-\mathrm{C} 21-\mathrm{C} 26$ & $33(4)$ \\
\hline $\mathrm{In} 1-\mathrm{N} 1-\mathrm{C} 5-\mathrm{C} 4$ & $-172.5(4)$ & $\mathrm{C} 26-\mathrm{C} 21-\mathrm{C} 22-\mathrm{C} 23$ & $0.0(8)$ \\
\hline $\mathrm{C} 3-\mathrm{C} 4-\mathrm{C} 5-\mathrm{N} 1$ & $1.4(9)$ & $\mathrm{C} 20-\mathrm{C} 21-\mathrm{C} 22-\mathrm{C} 23$ & $174.6(5)$ \\
\hline $\mathrm{C} 11-\mathrm{N} 2-\mathrm{C} 7-\mathrm{C} 8$ & $1.4(9)$ & $\mathrm{C} 21-\mathrm{C} 22-\mathrm{C} 23-\mathrm{C} 24$ & $-0.7(10)$ \\
\hline $\mathrm{In} 1-\mathrm{N} 2-\mathrm{C} 7-\mathrm{C} 8$ & $177.2(5)$ & $\mathrm{C} 22-\mathrm{C} 23-\mathrm{C} 24-\mathrm{C} 25$ & $1.2(11)$ \\
\hline $\mathrm{N} 2-\mathrm{C} 7-\mathrm{C} 8-\mathrm{C} 9$ & $-0.3(10)$ & $\mathrm{C} 23-\mathrm{C} 24-\mathrm{C} 25-\mathrm{C} 26$ & $-0.9(11)$ \\
\hline $\mathrm{C} 7-\mathrm{C} 8-\mathrm{C} 9-\mathrm{C} 10$ & $-0.9(9)$ & $\mathrm{C} 24-\mathrm{C} 25-\mathrm{C} 26-\mathrm{C} 21$ & $0.2(10)$ \\
\hline $\mathrm{C} 7-\mathrm{C} 8-\mathrm{C} 9-\mathrm{C} 12$ & $178.6(6)$ & $\mathrm{C} 22-\mathrm{C} 21-\mathrm{C} 26-\mathrm{C} 25$ & $0.3(9)$ \\
\hline $\mathrm{C} 8-\mathrm{C} 9-\mathrm{C} 10-\mathrm{C} 11$ & $1.1(9)$ & $\mathrm{C} 20-\mathrm{C} 21-\mathrm{C} 26-\mathrm{C} 25$ & $-174.5(5)$ \\
\hline $\mathrm{C} 12-\mathrm{C} 9-\mathrm{C} 10-\mathrm{C} 11$ & $-178.4(6)$ & $\mathrm{C} 31-\mathrm{N} 3-\mathrm{C} 27-\mathrm{C} 28$ & $-1.3(13)$ \\
\hline $\mathrm{C} 7-\mathrm{N} 2-\mathrm{C} 11-\mathrm{C} 10$ & $-1.2(8)$ & $\mathrm{N} 3-\mathrm{C} 27-\mathrm{C} 28-\mathrm{C} 29$ & $0.9(14)$ \\
\hline $\mathrm{In} 1-\mathrm{N} 2-\mathrm{C} 11-\mathrm{C} 10$ & $-177.2(4)$ & $\mathrm{C} 27-\mathrm{C} 28-\mathrm{C} 29-\mathrm{C} 30$ & $0.8(14)$ \\
\hline $\mathrm{C} 9-\mathrm{C} 10-\mathrm{C} 11-\mathrm{N} 2$ & $0.0(9)$ & $\mathrm{C} 27-\mathrm{C} 28-\mathrm{C} 29-\mathrm{C} 32$ & $178.0(10)$ \\
\hline $\mathrm{In} 1-\mathrm{O} 2-\mathrm{C} 13-\mathrm{O} 1$ & $-3.0(5)$ & $\mathrm{C} 28-\mathrm{C} 29-\mathrm{C} 30-\mathrm{C} 31$ & $-1.9(14)$ \\
\hline $\mathrm{In} 1-\mathrm{O} 2-\mathrm{C} 13-\mathrm{C} 14$ & $176.7(4)$ & $\mathrm{C} 32-\mathrm{C} 29-\mathrm{C} 30-\mathrm{C} 31$ & $-179.2(10)$ \\
\hline $\mathrm{In} 1-\mathrm{O} 1-\mathrm{C} 13-\mathrm{O} 2$ & $3.0(5)$ & $\mathrm{C} 27-\mathrm{N} 3-\mathrm{C} 31-\mathrm{C} 30$ & $0.0(14)$ \\
\hline $\mathrm{In} 1-\mathrm{O} 1-\mathrm{C} 13-\mathrm{C} 14$ & $-176.7(4)$ & $\mathrm{C} 29-\mathrm{C} 30-\mathrm{C} 31-\mathrm{N} 3$ & $1.5(15)$ \\
\hline
\end{tabular}




\begin{tabular}{|c|c|c|}
\hline \multicolumn{2}{|c|}{ REPORT DOCUMENTATION PAGE } & $\begin{array}{l}\text { Form Approved } \\
\text { OMB No. 0704-0188 }\end{array}$ \\
\hline \multicolumn{3}{|c|}{$\begin{array}{l}\text { The public reporting burden for this collection of information is estimated to average } 1 \text { hour per response, including the time for reviewing instructions, searching existing data sources, gathering and maintaining the } \\
\text { data needed, and completing and reviewing the collection of information. Send comments regarding this burden estimate or any other aspect of this collection of information, including suggestions for reducing this } \\
\text { burden, to Department of Defense, Washington Headquarters Services, Directorate for Information Operations and Reports (0704-0188), } 1215 \text { Jefferson Davis Highway, Suite } 1224 \text {, Allington, VA } 222202-4302 \text {. } \\
\text { Respondents should be aware that notwithstanding any other provision of law, no person shall be subject to any penalty for failing to comply with a collection of information if it does not display a currently valid OMB } \\
\text { control number. } \\
\text { PLEASE DO NOT RETURN YOUR FORM TO THE ABOVE ADDRESS. }\end{array}$} \\
\hline $\begin{array}{l}\text { 1. REPORT DATE (DD-MM-YYYY) } \\
01-12-2010\end{array}$ & $\begin{array}{l}\text { 2. REPORT TYPE } \\
\text { Technical Memorandum }\end{array}$ & 3. DATES COVERED (From - To) \\
\hline \multirow{3}{*}{\multicolumn{2}{|c|}{$\begin{array}{l}\text { 4. TITLE AND SUBTITLE } \\
\text { Synthesis of Two New Group } 13 \text { Benzoato-Chloro Complexes: A Structural Study of Gallium } \\
\text { and Indium Chelating Carboxylates }\end{array}$}} & 5a. CONTRACT NUMBER \\
\hline & & 5b. GRANT NUMBER \\
\hline & & 5c. PROGRAM ELEMENT NUMBER \\
\hline \multirow{3}{*}{\multicolumn{2}{|c|}{$\begin{array}{l}\text { 6. AUTHOR(S) } \\
\text { Duraj, Stan, A.; Hepp, Aloysius, F.; Woloszynek, Robert; Protasiewicz, John, D.; Dequeant, } \\
\text { Michael; Ren, Tong }\end{array}$}} & 5d. PROJECT NUMBER \\
\hline & & 5e. TASK NUMBER \\
\hline & & $\begin{array}{l}\text { 5f. WORK UNIT NUMBER } \\
\text { WBS 387498.01.03.02.05 }\end{array}$ \\
\hline \multicolumn{2}{|c|}{$\begin{array}{l}\text { 7. PERFORMING ORGANIZATION NAME(S) AND ADDRESS(ES) } \\
\text { National Aeronautics and Space Administration } \\
\text { John H. Glenn Research Center at Lewis Field } \\
\text { Cleveland, Ohio 44135-3191 }\end{array}$} & $\begin{array}{l}\text { 8. PERFORMING ORGANIZATION } \\
\text { REPORT NUMBER } \\
\text { E-17455 }\end{array}$ \\
\hline \multirow{2}{*}{\multicolumn{2}{|c|}{$\begin{array}{l}\text { 9. SPONSORING/MONITORING AGENCY NAME(S) AND ADDRESS(ES) } \\
\text { National Aeronautics and Space Administration } \\
\text { Washington, DC 20546-0001 }\end{array}$}} & $\begin{array}{l}\text { 10. SPONSORING/MONITOR'S } \\
\text { ACRONYM(S) } \\
\text { NASA }\end{array}$ \\
\hline & & $\begin{array}{l}\text { 11. SPONSORING/MONITORING } \\
\text { REPORT NUMBER } \\
\text { NASA/TM-2010-216826 }\end{array}$ \\
\hline \multicolumn{3}{|c|}{$\begin{array}{l}\text { 12. DISTRIBUTIONIAVAILABILITY STATEMENT } \\
\text { Unclassified-Unlimited } \\
\text { Subject Categories: } 25 \text { and } 44 \\
\text { Available electronically at http://gltrs.grc.nasa.gov } \\
\text { This publication is available from the NASA Center for AeroSpace Information, 443-757-5802 }\end{array}$} \\
\hline
\end{tabular}

\section{SUPPLEMENTARY NOTES}

\section{ABSTRACT}

Two new heteroleptic chelated-benzoato gallium (III) and indium (III) complexes have been prepared and structurally characterized. The molecular structures of $\left[\mathrm{GaCl}_{2}(4-\mathrm{Mepy})_{2}\left(\mathrm{O}_{2} \mathrm{CPh}\right)\right] 4-\mathrm{Mepy}(1)$ and $\left[\mathrm{InCl}(4-\mathrm{Mepy})_{2}\left(\mathrm{O}_{2} \mathrm{CPh}\right)_{2}\right] 4$-Mepy (2) have been determined by singlecrystal x-ray diffraction. The gallium compound (1) is a distorted octahedron with cis-chloride ligands co-planar with the chelating benzoate and the 4-methylpyridines trans to each other. This is the first example of a Ga(III) structure with a chelating benzoate. The indium compound (2) is a distorted pentagonal bipyramid with two chelating benzoates, one 4-methylpyridine in the plane and a chloride trans to the other 4-methylpyridine. The indium bis-benzoate is an unusual example of a seven-coordinate structure with classical ligands. Both complexes, which due to the chelates, could also be described as pseudo-trigonal bipyramidal, include a three-bladed motif with three roughly parallel aromatic rings that along with a solvent of crystallization and electron-withdrawing chloride ligand(s) stabilize the solidstate structures.

\section{SUBJECT TERMS}

Indium compounds; Gallium compounds; Chlorides; Vapor deposition; Solar cells; Crystal structure

\begin{tabular}{|c|c|c|c|c|c|}
\hline \multicolumn{3}{|c|}{ 16. SECURITY CLASSIFICATION OF: } & \multirow{2}{*}{$\begin{array}{l}\text { 17. LIMITATION OF } \\
\text { ABSTRACT } \\
\text { UU }\end{array}$} & \multirow{2}{*}{$\begin{array}{l}\text { 18. NUMBER } \\
\text { OF } \\
\text { PAGES } \\
36\end{array}$} & \multirow{2}{*}{$\begin{array}{l}\text { 19a. NAME OF RESPONSIBLE PERSON } \\
\text { STI Help Desk (email:help@sti.nasa.gov) } \\
\text { 19b. TELEPHONE NUMBER (include area code) } \\
\text { 443-757-5802 }\end{array}$} \\
\hline $\begin{array}{l}\text { a. REPORT } \\
U\end{array}$ & $\begin{array}{l}\text { b. ABSTRACT } \\
\text { U }\end{array}$ & $\begin{array}{l}\text { c. THIS } \\
\text { PAGE } \\
\text { U }\end{array}$ & & & \\
\hline
\end{tabular}



